\title{
De arbeidsmarkt naar opleiding en beroep tot 1994
}

\author{
Citation for published version (APA):
}

Researchcentrum voor Onderwijs en Arbeidsmarkt, ROA. (1992). De arbeidsmarkt naar opleiding en beroep tot 1994. Researchcentrum voor Onderwijs en Arbeidsmarkt, Faculteit der Economische Wetenschappen. ROA Reports No. 001 https://doi.org/10.26481/umarep.1992001

Document status and date:

Published: 01/01/1992

DOI:

10.26481/umarep.1992001

Document Version:

Publisher's PDF, also known as Version of record

\section{Please check the document version of this publication:}

- A submitted manuscript is the version of the article upon submission and before peer-review. There can be important differences between the submitted version and the official published version of record.

People interested in the research are advised to contact the author for the final version of the publication, or visit the DOI to the publisher's website.

- The final author version and the galley proof are versions of the publication after peer review.

- The final published version features the final layout of the paper including the volume, issue and page numbers.

Link to publication

\footnotetext{
General rights rights.

- You may freely distribute the URL identifying the publication in the public portal. please follow below link for the End User Agreement:

www.umlib.nl/taverne-license

Take down policy

If you believe that this document breaches copyright please contact us at:

repository@maastrichtuniversity.nl

providing details and we will investigate your claim.
}

Copyright and moral rights for the publications made accessible in the public portal are retained by the authors and/or other copyright owners and it is a condition of accessing publications that users recognise and abide by the legal requirements associated with these

- Users may download and print one copy of any publication from the public portal for the purpose of private study or research.

- You may not further distribute the material or use it for any profit-making activity or commercial gain

If the publication is distributed under the terms of Article $25 \mathrm{fa}$ of the Dutch Copyright Act, indicated by the "Taverne" license above, 
DE ARBEIDSMARKT NAAR OPLEIDING EN BEROEP TOT 1994

ROA-R-1992/1

RESEARCHCENTRUM VOOR ONDERWIJS EN ARBEIDSMARKT

Rijksuniversiteit Limburg

Faculteit der Economische Wetenschappen

Maastricht, februari 1992 
Niets uit deze uitgave mag worden verveelvoudigd en/of openbaar gemaakt door middel van druk, fotocopie, microfilm, of op welke wijze ook "zonder voorafgaande schriftelijke toestemming van de directeur van het Researchcentrum voor Onderwijs en Arbeidsmarkt. In geval van overname van het data-materiaal moet telkens als bronvermelding worden vermeld: "Researchcentrum voor Onderwijs en Arbeidsmarkt" of "ROA".

CIP-GEGEVENS KONINKLIJKE BIBLIOTHEEK, DEN HAAG

\section{Arbeidsmarkt}

De arbeidsmarkt naar opleiding en beroep tot 1994/ Researchcentrum voor Onderwijs en Arbeidsmarkt. - Maastricht : Researchcentrum voor Onderwijs en Arbeidsmarkt, Rijksuniversiteit Limburg, Faculteit der Economische Wetenschappen. - (ROA-R-1992/1). Met lit.opg.

ISBN 90-5321-077-6 geb.

Trefw.: arbeidsmarkt; Nederland; toekomst / onderwijs en arbeidsmarkt ; Nederland; toekomst. 


\section{TEN GELEIDE}

Wij hebben het genoegen met dit ten geleide het rapport "De arbeidsmarkt naar opleiding en beroep tot 1994" van het Researchcentrum voor Onderwijs en Arbeidsmarkt te Maastricht in uw aandacht aan te bevelen. Het is een van de produkten uit het ROA-informatiesysteem onderwijs-arbeidsmarkt.

De aanleiding tot de ontwikkeling van dit systeem vormde een geconstateerd 'gat' in de informatie over de mate waarin het aanbod van arbeidskrachten vanuit het onderwijs, aansluit bij de vraag van de arbeidsmarkt. Er bleek behoefte aan cijfers, statistieken en prognoses over de uitstroom naar kwalificatie van leerlingen uit het onderwijs naar de arbeidsmarkt. Tevens bestond er behoefte aan prognoses over werkgelegenheidsgroei en vervangingsbehoefte in beroepen en opleidingstypen. Door een confrontatie van vraag en aanbod ontstaat een beeld van te verwachten discrepanties. Het projekt-produkt diende zichtbaar te maken in welke opleidingstypen een overschot danwel een tekort aan aanbod van gekwalificeerde schoolverlaters dreigt op te treden. Een dergelijk beeld kan een handreiking bieden aan de studie en beroepskeuzevoorlichting en de beleidsontwikkeling op diverse niveaus.

De voorliggende beleidsgerichte rapportage biedt een boeiend beeld van de complexe relatie tussen opleiding en beroep. De relatie tussen gevolgde opleiding en de beroepsuitoefening is vaak zeer gevarieerd. Het rapport geeft een duidelijk inzicht in de mate waarin specifieke opleidingen sterk beroepsgebonden zijn, danwel een bredere transferwaarde bezitten naar diverse beroepen. Daarmee komt ook de mate van flexibiliteit van de kwalificatievoorziening en de marktpositie van de diverse opleidingen goed voor het voetlicht.

Het Ministerie van Onderwijs en Wetenschappen, het Centraal Bestuur voor de Arbeidsvoorziening en het Landelijk Dienstverlenend Centrum hebben inmiddels besloten tot prolongatie van de opdracht aan het ROA. Naast handhaving van de huidige projektopbrengsten zal tevens worden gestreefd naar een koppeling van de gegevensmetingen met die van ander schoolverlatersonderzoek als het RUBS-onderzoek (Registratie van Uitstroom en Bestemming van Schoolverlaters). Voorts zal verdere regionalisering van de metingen en rapportages worden gestimuleerd, met als doel de regio-specifieke aansluitingsproblematiek van onderwijs en arbeidsmarkt zichtbaar te maken en zo directere mogelijkheden tot bijsturing te bieden.

Wij hopen met deze plaatsbepaling van het rapport een deel van ons enthousiasme op $u$ te hebben overgebracht en zijn benieuwd of toekomstige rapportages reeds effecten zichtbaar maken van mede op basis van dit systeem gemaakte keuzes van leerlingen, opleidingenaanbieders en beleidsmakers.

De Minister van

Onderwijs en Wetenschappen
De Voorzitter van het

Centraal Bestuur voor de

Arbeidsvoorziening

R. de Boer 
2.1. Inleiding

2.2. Uitbreidingsvraag

2.3. Vervangingsvraag

2.4. Baanopeningen

2.5. Instroom van schoolverlaters

3.2. De marktpositie van beroepen 31

3.3. De marktpositie van opleidingen

4.1. Inleiding 43

4.2. Ontwikkeling van de kwalificatiestructuur van het arbeidsaanbod 43

4.3. De marktpositie van technische beroepen $\quad 45$

4.4. De marktpositie van technische opleidingen 50

5. SEXE, ONDERWIJS EN ARBEIDSMARKT

5.1. Inleiding 56

5.2. Participatie en segregatie 56

5.3. De marktpositie van vrouwenberoepen 58

5.4. De marktpositie van vrouwenopleidingen 63 


\section{VOORWOORD}

Het Researchcentrum voor Onderwijs en Arbeidsmarkt (ROA) heeft de afgelopen jaren in opdracht van het Ministerie van Onderwijs en Wetenschappen het informatiesysteem onderwijsarbeidsmarkt ontwikkeld. Het project wordt thans voortgezet in het kader van een opdrachtverlening door het Ministerie van Onderwijs en Wetenschappen, het Centraal Bestuur voor de Arbeidsvoorziening (CBA) en het Landelijk Dienstverlenend Centrum voor Studie en Beroepskeuzevoorlichting (LDC). Het informatiesysteem heeft als doel het verschaffen van actuele gegevens en middellange-termijn prognoses over de positie van beroepen en opleidingen op de arbeidsmarkt. De informatie vindt via verschillende media zijn weg naar meerdere gebruikers.

In de eerste plaats worden de gegevens van het informatiesysteem ingepast in het geautomatiseerde informatiesysteem voor studie- en beroepskeuze I-See! Information-Systeem on education and employment). Dit systeem, een project van het LDC, bevat een aanzienlijke hoeveelheid gegevens op CD-ROM over circa 1.500 beroepen en ruim 17.000 opleidingen. Deze informatie wordt in I-See! gekoppeld aan de door het ROA verstrekte arbeidsmarktinformatie over beroepen en opleidingen. Op deze wijze wordt voorzien in de behoefte aan arbeidsmarktinformatie bij de studie- en beroepskeuzevoorlichting.

Het voorliggende rapport is een tweede belangrijke toepassing van het informatiesysteem. De doelstelling van dit rapport is het signaleren van de belangrijkste trends op de arbeidsmarkt, waarbij de nadruk ligt op de kwantitatieve aansluiting tussen het onderwijs en de arbeidsmarkt en de verwachte toekomstige ontwikkelingen hierin. De in dit rapport weergegeven prognoses hebben betrekking op de periode 1989-1994. Het rapport zal voortaan een keer per twee jaar verschijnen.

Het rapport is in eerste instantie bedoeld voor degenen die zich beleidsmatig bezighouden met het vraagstuk van de aansluiting van het onderwijs op de arbeidsmarkt: de overheid, de arbeidsvoorzieningsorganisatie, de sociale partners en het onderwijsveld. Het rapport gaat vrijwel niet in op de gehanteerde onderzoeksmethoden. Daarvoor wordt verwezen naar Dekker, De Grip, Berendsen, Wieling en Willems (1992) en naar de meer specifieke werkdocumenten en research-memoranda van het ROA.

Zoals reeds is aangegeven, bevat het rapport voornamelijk actuele data, indicatoren en prognoses met betrekking tot de kwantitatieve aansluiting tussen het onderwijs en de arbeidsmarkt. Hierbij wordt in belangrijke mate gesteund op de arbeidsmarktgegevens van het Centraal Bureau voor de Statistiek (CBS). Het is daarbij van belang om te vermelden dat door bij het CBS gestationeerde ROA-medewerkers tabellen zijn samengesteld uit de Enquetes Beroepsbevolking (EBB) 1988-1990. De EBB-opleidingsgegevens zijn pas vanaf 1990 beschikbaar. Daarbij moet worden opgemerkt dat het CBS enkele publikatierestricties aan de tabellen heeft gesteld. Als gevolg daarvan is het niet mogelijk informatie te verstrekken voor vijf kleine beroepsklassen ('landbouwkundige vakspecialisten', 'lijnwerkers, kabelmonteurs en -lassers', 'middelbare elektrotechnici', 'vissers, vis- en schaaldierkwekers, jagers e.d.' en 'diergeneeskundigen, 
veterinaire geneeskundigen') en twee opleidingstypen ('HBO Horeca' en 'WO Farmacie').

Door het verschil in enquête-opzet tussen de EBB en de voorloper hiervan, de Arbeidskrachtentelling (AKT), kan geen beschrijving worden gegeven van de trends op de arbeidsmarkt in de tweede helft van de jaren ' 80 . Ook voor de ROA-prognosemodellen levert de trendbreuk tussen de AKT- en de EBB-data vooralsnog problemen op. Derhalve is voor het uitvoeren van de modelschattingen slechts gebruik gemaakt van de AKT-gegevens. De prognoseresultaten zijn uiteindelijk wel 'gewogen' tot EBB-waarden. Er kan overigens worden opgemerkt dat door het ROA spoedig een onderzoek zal worden gestart naar de mogelijkheid tot koppeling van de AKTen de EBB-data.

Het rapport bestaat in feite uit drie delen. In hoofdstuk 1 worden in globale lijnen enkele actuele arbeidsmarktgegevens besproken en komen de ontwikkelingen op de arbeidsmarkt in het recente verleden en de verwachte ontwikkelingen tot 1994 aan de orde. De informatie wordt daarbij gepresenteerd op relatief hoge aggregatieniveaus van bedrijfstakken, beroepssectoren en opleidingscategorieën.

In het tweede deel van het rapport worden op het aggregatieniveau van beroepsklassen en opleidingstypen de belangrijkste gegevens van het informatiesysteem onderwijs-arbeidsmarkt gepresenteerd. In hoofdstuk 2 wordt ingegaan op de verwachte toekomstige stromen op de arbeidsmarkt. In hoofdstuk 3 komen de marktposities van de diverse beroepsklassen en opleidingstypen aan de orde.

In het derde deel worden twee thema's behandeld. In hoofdstuk 4 wordt vanwege de grote beleidsrelevantie het technisch onderwijs nader belicht. In hoofdstuk 5 staat de relatie tussen sexe, onderwijs en arbeidsmarkt centraal. In beide hoofdstukken wordt ingegaan op de marktpositie van de voor het desbetreffende thema relevante beroepsklassen en opleidingstypen.

Tot slot wordt gewezen op de in aansluiting op dit rapport verschenen statistische bijlage, waarin de kwantitatieve informatie die in dit rapport aan de orde komt, wordt verstrekt voor alle onderscheiden beroepsklassen en opleidingstypen, aangevuld met enkele additionele gegevens. Deze bijlage zal jaarlijks worden geactualiseerd.

De opbouw van het informatiesysteem onderwijs-arbeidsmarkt stond onder leiding van prof. $d r$. J.A.M. Heijke. De dagelijkse leiding berustte bij dr. A. de Grip. De eindredactie van het rapport was in handen van drs. E.J.T.A. Willems. Drs. R.J.P. Dekker was verantwoordelijk voor de coördinatie van de verwerking van de gegevens. Dr. R.K.W. van der Velden verzorgde de ontwikkeling van het prototype van dit rapport. Verder zijn bijdragen geleverd door drs. $H$. Berendsen, drs. P.J.E. van de Loo, drs. G.W.M. Ramaekers en drs. M.H. Wieling.

Prof. dr. J.A.M. Heijke

Directeur 


\section{ONTWIKKELINGEN OP DE ARBEIDSMARKT}

De belangstelling voor de aansluitingsproblematiek van onderwijs en arbeidsmarkt blijft onverminderd groot. Terwijl op sommige segmenten van de arbeidsmarkt tekorten aan gekwalificeerd personeel bestaan, naar voren komend in een groot aantal openstaande en moeilijk vervulbare vacatures, geldt voor andere arbeidsmarktsegmenten nog steeds een hoge werkloosheid (zie ook Ministerie van Sociale Zaken on Werkgelegenheid, 1991). In dit hoofdstuk wordt een globaal overzicht gegeven van enkele actuele arbeidsmarktgegevens en wordt ingegaan op de arbeidsmarktontwikkelingen in het recente verleden on de verwachte ontwikkelingen op middellange termijn. Deze informatie wordt op een relatief hoog aggregatieniveau gepresenteerd. Voor een meer gedetailleerd beeld wordt verwezen naar de hoofdstukken 2 en 3.

De opzet van dit hoofdstuk is als volgt. Eerst wordt aandacht besteed aan de ontwikkelingen in de sectorstructuur van de werkzame bevolking en aan de kwalificatiestructuur van het arbeidsaanbod van nieuwkomers op de arbeidsmarkt. Daarna wordt ingegaan op de omvang van de werkgelegenheid van clusters van beroepen en opleidingen in 1990. Bovendien wordt nagegaan hoe deze werkgelegenheid zich in de periode 1979-1985 heeft ontwikkeld en welke tendensen voor de periode 1989-1994 worden verwacht. Aan het slot van het hoofdstuk komt de marktpositie van opleidingen aan de orde. Daarbij wordt zowel ingegaan op de huidige werkloosheid als op de toekomstige arbeidsmarktperspectieven voor nieuwkomers op de arbeidsmarkt en het risico van een bepaalde opleidingskeuze.

\section{Ontwikkeling van de sectorstructuur van de werkzame bevolking}

In tabel 1.1. wordt een overzicht gegeven van de verdeling van de werkzame bevolking naar bedrijfstak in 1990. Het blijkt dat een groot gedeelte van de totale werkzame bevolking van ruim 6,4 miljoen is geconcentreerd in de dienstensectoren. In 1990 is ongeveer een kwart van de werkenden actief in de primaire of secundaire sector. Het aandeel van de tertiaire sector in de werkgelegenheid bedraagt circa $45 \%$ en het aandeel van de kwartaire sector ongeveer $30 \%$.

Tabel 1.2. geeft een beeld van de sectorale werkgelegenheidsontwikkelingen in de periode 1979-1985 en de verwachte ontwikkeling van de sectorstructuur van de werkzame bevolking in de prognoseperiode 1989-1994. De opgetreden recessie in het begin van de jaren ' 80 is hier duidelijk zichtbaar: de totale werkgelegenheid is in de periode 1979-1985 met gemiddeld 0,3\% per jaar gedaald. Daarbij kan overigens worden opgemerkt dat de daling van het arbeidsvolume nog groter is geweest; de toename van het aantal deeltijdwerkenden heeft echter voor enige compensatie gezorgd.

De werkgelegenheidsdaling heeft zich in een groot aantal bedrijfstakken voorgedaan. De daling is het grootst geweest in de kleding- en schoenenindustrie en in de bouw. In de commerciäle dienstverlening, de kwartaire diensten en bij het openbaar bestuur, politie en defensie en het 
onderwijs is er daarentegen sprake geweest van werkgelegenheidsgroei. Met name de groei van de kwartaire diensten met gemiddeld 3,8\% per jaar is daarbij opvallend.

Tabel 1.1. Aantal werkenden per bedrijfstak 1990

Bedrijfstak

aantal werkenden

Landbouw, visserij en bosbouw

301.000

Voedings- en genotmiddelenindustrie

175.000

Kleding-en schoenenindustrie

58.000

Hout- en bouwmaterialen-, papier- en grafische industrie

251.000

Chemie

Metaal, electrotechnische en transportmiddelenindustrie

139.000

555.000

Energie

51.000

Delfstoffen

11.000

Bouw

412.000

Handel

961.000

Vervoer en communicatie

380.000

Commerciele dienstverlening

1.087 .000

Kwartaire diensten

1.049 .000

Openbaar bestuur, politie en defensie en onderwijs

913.000

Totaal (incl. woningbezit en bedrijfstak onbekend)

6.420 .000

Bron: CBS/ROA

Tabel 1.2. Werkgelegenheidsontwikkeling per bedrijfstak (werkzame personen) 1979-1985 en 19891994 (gemiddelde jaarlijkse groeil

Bedrijfstak

1979-1985

Landbouw, visserij en bosbouw

$-1,6$

$-0,4$

Voedings- en genotmiddelenindustrie

$-1,1$

$-0,9$

Kleding* en schoenenindustrie

Hout- en bouwmaterialen-, papier en grafische industrie

$-5,7$

$-0,7$

Chemie

Metaal, electrotechnische en transportmiddelenindustrie

$-2,6$

0,0

Energie

$-0,7$

1,4

Delfstoffen

$-2,1$

0,3

$-0,5$

0,4

Bouw

$-0,4$

0,2

Handel

Vervoer en communicatie

$-4,9$

$-0,1$

Commerciêle dienstverlening

$-0,9$

2,1

$-0,9$

1,1

Kwartaire diensten

Openbaar bestuur, politie en defensie en onderwijs

0,8

1,8

3,8

1,3

1,3

0,2

Totaal (incl. woningbezit en bedrijfstak onbekend)

$-0,3$

0,9 
Voor de periode 1989-1994 wordt een groei van de werkgelegenheid verwacht van gemiddeld $0,9 \%$ per jaar. Daarbij kan worden opgemerkt dat de verschillen tussen de bedrijfstakken in de verwachte ontwikkeling van de aantallen werkzame personen minder pregnant zijn dan in de periode 1979-1985. De dienstensectoren profiteren naar verwachting het meest van de economische groei, zodat de reeds sinds het begin van de jaren ' 80 optredende tertiairisering en kwartairisering van de werkgelegenheidsstructuur zich zal voortzetten. Verder is de relatief hoge groei van de chemische sector opvallend. Voor de landbouw, visserij en bosbouw, de voedingsen genotmiddelenindustrie, de kleding en schoenenindustrie en in mindere mate de bouw wordt een (geringe) daling van het aantal werkenden verwacht.

\section{Ontwikkeling van de kwalificatiestructuur van het arbeidsaanbod}

Figuur 1.1. Ontwikkeling gediplomeerde uitstroom uit het initiële dagonderwijs per opleidingsniveau 19791985 en 1989-1994 (gemiddelde jaarlijkse groei)

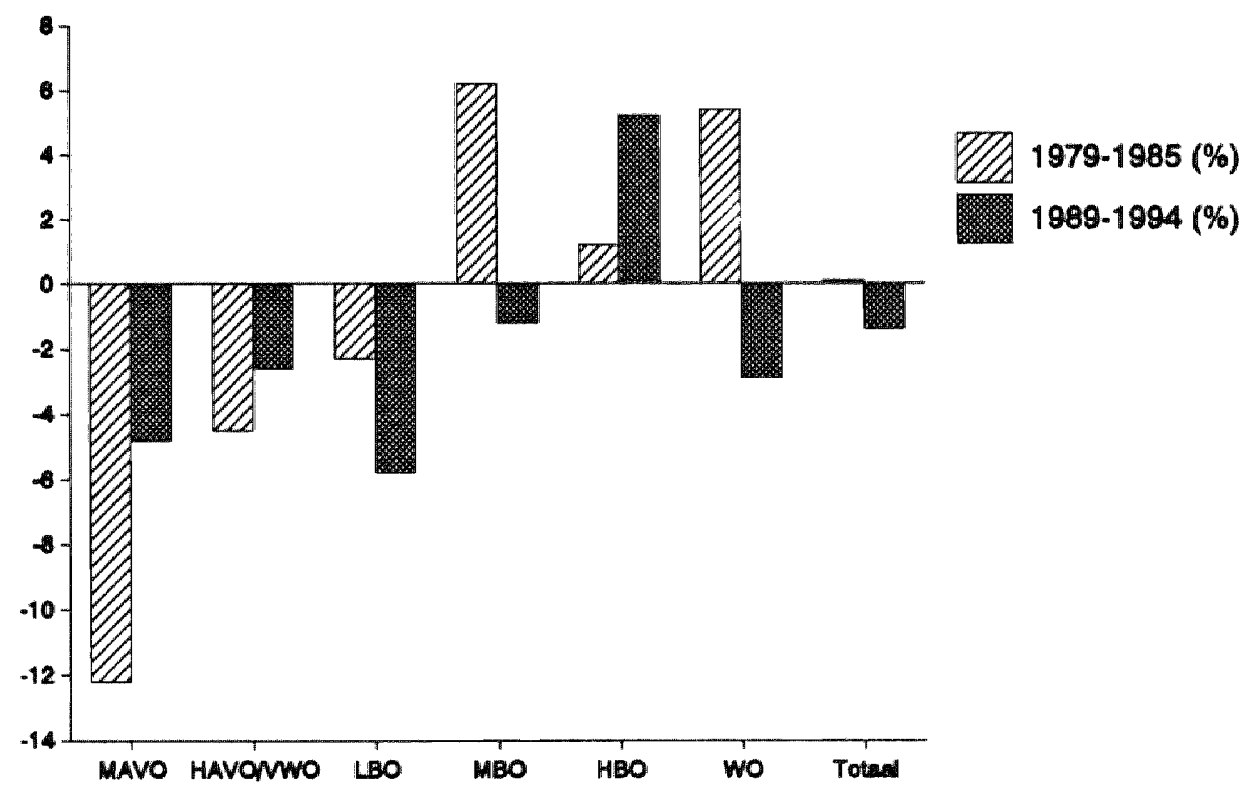

Bron: CBS/Ministerie van Onderwijs en Wetenschappen

In figuur 1.1. wordt aan de hand van de veranderingen voor de gediplomeerde uitstroom uit het initiële dagonderwijs een indicatie gegeven van de ontwikkeling van het kwalificatieprofiel van 
de nieuwkomers op de arbeidsmarkt' in de perioden 1979-1985 en 1989-1994. De totale gediplomeerde uitstroom uit het initiële dagonderwijs is in de periode 1979-1985 min of meer constant gebleven. Voor de onderscheiden opleidingsniveaus is de ontwikkeling echter geheel verschillend. De grote krimpgroepen in deze periode zijn het algemeen voortgezet onderwijs (MAVO en HAVO/VWO) en het lager beroepsonderwijs (LBO). De grootste groeicategorieën zijn het middelbaar beroepsonderwijs (MBO) en het wetenschappelijk onderwijs (WO). Voor de prognoseperiode 1989-1994 wordt een geheel ander beeld verwacht. De totale gediplomeerde uitstroom uit het onderwijs neemt in deze periode met gemiddeld bijna 1,5\% af. Wederom behoren de algemeen vormende opleidingen en het LBO tot de grootste verliezers. Opvallend is echter dat ook het aantal gediplomeerde MBO-schoolverlaters en het aantal academische afgestudeerden naar verwachting afneemt. Het aantal afgestudeerden van het hoger beroepsonderwijs (HBO) zal daarentegen fors toenemen met ruim $5 \%$ gemiddeld per jaar.

\section{De werkgelegenheid van beroepen en opleidingen}

Tabel 1.3. Aantal werkenden per beroepssector 1990

code

$\begin{array}{ll}0 & \text { Pedagogische beroepen } \\ 1 & \text { Culturele beroepen } \\ 2 & \text { Agrarische beroepen } \\ 3 & \text { Technische, ambachts- en industrieberoepen } \\ 4 & \text { Transportberoepen } \\ 5 & \text { Medische en paramedische beroepen } \\ 6 & \text { Economisch-administratieve beroepen } \\ 7 & \text { Sociaal-culturele beroepen } \\ 8 & \text { Verzorgende en dienstverlenende beroepen } \\ 9 & \text { Openbare orde- en veiligheidsberoepen }\end{array}$

Bron: CBS/ROA

Om een beeld te geven van de verdeling van de werkgelegenheid over de beroepen en opleidingen wordt in tabel 1.3. en 1.4. respectievelijk het aantal werkenden per beroepssector en per opleidingscategorie gepresenteerd. De beroepssector-indeling is daarbij gebaseerd op de eerste digit van de ROA-beroepenclassificatie 1990 (zie Dekker, De Grip en Van de Loo, 1990). De indeling in opleidingscategorieën is gelijk aan de door het Centraal Planbureau (CPB)

1. Het betreft hier alleen de schoolverlaters van het initiële dagonderwijs. Het basisonderwijs blijft daarbij buiten beschouwing. Overigens worden in de verdere hoofdstukken ook de afgestudeerden van het deeltijdonderwijs, het niet-reguliere onderwijs en de volwasseneneducatie tot het aanbod van nieuwkomers op de arbeidsmarkt fvoor een bepaald opleidingstype) gerekend. 
gehanteerde indeling (zie CPB, 1987) ${ }^{2}$.

Uit tabel 1.3. blijkt dat het grootste deel van de arbeidskrachten in 1990 werkzaam is in de economisch-administratieve en de technische, ambachts- en industrieberoepen. Deze twee beroepssectoren vertegenwoordigen samen ongeveer $60 \%$ van de totale werkgelegenheid. Tabel 1.4. geeft aan dat circa $40 \%$ van de werkenden een opleiding op middelbaar niveau heeft afgerond. Ruim $35 \%$ van de arbeidskrachten heeft een (uitgebreid) lagere opleiding gevolgd. Ongeveer $20 \%$ van alle werkenden heeft een opleidingsachtergrond op universitair niveau of het niveau van hoger beroepsonderwijs.

Tabel 1.4. Aantal werkenden per opleidingscategorie 1990

Opleidingscategorie

aantal werkenden

Lager

- algemeen

691.000

Uitgebreid lager

algemeen/economisch

696.000

technisch/agrarisch

684.000

verzorgend

282.000

Middelbaar

algemeen

345.000

technisch/agrarisch

862.000

economisch

743.000

verzorgend

640.000

Hoger

- technisch/agrarisch

economisch

290.000

verzorgend

728.000

Totaal (incl. overige opleidingen en opleiding onbekend)

6.420 .000

Bron: CBS/ROA

\section{De werkgelegenheidsontwikkeling van beroepen en opleidingen}

In tabel 1.5. wordt een beeld geschetst van de werkgelegenheidsontwikkeling van de tien onderscheiden beroepssectoren in de periode 1979-1985 en 1989-1994. De grootste groeisector in de (recessie)periode 1979-1985 wordt gevormd door de openbare orde- en veiligheidsberoepen. De jaarlijkse groei van het aantal werkenden in deze beroepssector bedraagt gemiddeld maar liefst ruim $12 \%$ per jaar. De tweede plaats op de lijst van 'occupational

2. Daarbij moet worden opgemerkt dat met name de door het CPB onderscheiden opleidingsrichting 'verzorgend' een veel ruimere opleidingsrichting vertegenwoordigt dan de benaming suggereert. 
winners' wordt ingenomen door de medische en paramedische beroepen, op de voet gevolgd door de sociaal-culturele beroepen. Andere groeisectoren in de periode 1979-1985 zijn de culturele beroepen, de economisch-administratieve beroepen en de verzorgende en dienstverlenende beroepen. Daarentegen is de werkgelegenheid gedaald in de pedagogische beroepen, de agrarische beroepen, de technische, ambachts- en industrieberoepen en de transportberoepen. De trend, zoals die is geconstateerd in de (bedrijfs)sectorstructuur van de werkgelegenheid, kan derhalve worden teruggezien in de beroepenstructuur. De groeiberoepen zijn met name de beroepen in de dienstverlenende sfeer, terwijl de daling van de werkgelegenheid zich met name heeft voorgedaan in de beroepen in de agrarische en de industriesector.

Tabel 1.5. Werkgelegenheidsontwikkeling per beroepssector 1979-1985 en 1989-1994 lgemiddelde jaarlijkse groeil

ROA- beroepssector

1979-1985

$1989-1994$

code

Pedagogische beroepen

\section{$-3,3$}

$-0,2$

Culturele beroepen

Agrarische beroepen

1,2

0,4

$-1,0$

$-3,0$

Technische, ambachts- en industrieberoepen

$-1,8$

0,4

Transportberoepen

Medische en paramedische beroepen

$-0,5$

1,2

Economisch-administratieve beroepen

5,3

1,2

2,0

2,0

Sociaal-culturele beroepen

5,2

3,1

Verzorgende en dienstverlenende beroepen

3,5

3,3

Openbare orde- en veiligheidsberoepen

12,4

2,4

Totaal (incl. beroep onbekend)

$-0,3$

0,9

Bron: CBS/ROA

De verwachte groei van de werkgelegenheid in de periode 1989-1994 doet zich in vrijwel alle onderscheiden beroepssectoren voor. De groei is daarbij naar verwachting het grootst voor de verzorgende en dienstverlenende beroepen en de sociaal-culturele beroepen. Ook wordt een aanzienlijke groei verwacht voor de openbare orde- en veiligheidsberoepen en de economischadministratieve beroepen. Opvallend is de grote afname van de werkgelegenheid die wordt verwacht voor de agrarische beroepen. Het aantal werkenden in deze beroepssector zal naar verwachting met maar liefst 3\% gemiddeld per jaar dalen. Dit hangt samen met enerzijds de verwachte werkgelegenheidsdaling in de agrarische sector en anderzijds de afnemende vertegenwoordiging van de agrarische beroepen binnen de verschillende sectoren.

Voor de 11 onderscheiden opleidingscategorieën wordt in de eerste kolom van tabel 1.6. de gemiddelde jaarlijkse groei van de werkgelegenheid in de periode 1979-1985 gepresenteerd. Het is duidelijk zichtbaar dat het gemiddeld opleidingsniveau van de (actieve) beroepsbevolking in deze periode is toegenomen (zie bijvoorbeeld ook De Grip, 1987). Terwij) voor de lagere opleidingsniveaus een afname van de werkgelegenheid wordt geconstateerd, is een sterke 
toename van het aantal werkenden op middelbaar en hoger niveau waarneembaar. Bovendien is er sprake van een zogenaamde 'specialiseringstrend', dat wil zeggen dat een groter deel van de arbeidskrachten een beroepsopleiding in plaats van een algemeen vormende opleiding heeft gevolgd (zie ook De Grip, Groot, Heijke en Willems, 1990). Het is daarbij overigens opvallend dat de werkgelegenheidsontwikkeling voor het technisch/agrarisch onderwijs is achtergebleven bij die van de andere opleidingsrichtingen. Vanzelfsprekend hangt deze specialiseringstendens samen met de eerder genoemde stijging van het opleidingsniveau van de werkenden.

Tabel 1.6. Werkgelegenheidsontwikkeling per opleidingscategorie 1979-1985 en 1989-1994 (gemiddelde jaarlijkse groei)

\begin{tabular}{|c|c|c|}
\hline Opleidingscategorie & $\begin{array}{c}1979-1985 \\
\%\end{array}$ & $\begin{array}{c}1989-1994 \\
\%\end{array}$ \\
\hline \multicolumn{3}{|l|}{ Lager } \\
\hline algemeen & $-7,1$ & $-2,4$ \\
\hline \multicolumn{3}{|l|}{ Uitgebreid lager } \\
\hline algemeen/economisch & $-1,2$ & 0,7 \\
\hline technisch/agrarisch & $-1,7$ & $-0,9$ \\
\hline - verzorgend & 0,9 & 3,3 \\
\hline \multicolumn{3}{|l|}{ Middelbaar } \\
\hline algemeen & 5,5 & 0,4 \\
\hline technisch/agrarisch & 1,5 & 0,8 \\
\hline economisch & 7.1 & 3,2 \\
\hline verzorgend & 6,2 & 3,9 \\
\hline \multicolumn{3}{|l|}{ Hoger } \\
\hline technisch/agrarisch & 3.9 & 4,4 \\
\hline economisch & 10,0 & 3,7 \\
\hline verzorgend & 5,4 & 1,2 \\
\hline Totaal (incl. overige opleidingen en opleiding onbekend) & $-0,3$ & 0,9 \\
\hline
\end{tabular}

Bron: CBS/ROA

Uit de tweede kolom van tabel 1.6. blijkt dat voor de meeste opleidingstypen in de periode 1989-1994 een toename van de werkgelegenheid wordt verwacht. Hoewel duidelijk achterblijvend bij de periode 1979-1985 is deze groei het grootst voor de hogere en middelbare opleidingen. Een uitzondering wordt gevormd door de middelbare algemeen vormende en de middelbare technisch/agrarische richtingen, waarvoor slechts een geringe stijging van de werkgelegenheid wordt verwacht. Opvallend is de verwachte werkgelegenheidsgroei van maar liefst 3,3\% per jaar voor de verzorgend opgeleiden op lager niveau. De werkgelegenheid van ongeschoolde arbeidskrachten (de drop-outs van het voortgezet onderwijs) neemt in de prognoseperiode naar verwachting verder af, ofschoon de daling van de werkgelegenheid van deze groep aanmerkelijk lager is dan in de periode 1979-1985. Voor het lager technisch/ agrarisch onderwijs wordt een afname van de werkgelegenheid verwacht van circa $0,9 \%$ gemiddeld per jaar. 


\section{De marktpositie van opleidingen}

De hierboven beschreven (verwachte) werkgelegenheidsontwikkeling per opleidingscategorie vertelt vanzelfsprekend niet het hele verhaal over de (toekomstige) arbeidsmarktpositie van afgestudeerden van de desbetreffende opleidingen. Om het beeld van de marktpositie van opleidingen te complementeren zal ook worden gekeken naar de huidige werkloosheid per opleidingscategorie. Bovendien zal worden ingegaan op de verwachte arbeidsmarktperspectieven voor de nieuwkomers op de arbeidsmarkt, door de verwachte totale vraag naar nieuwkomers af te zetten tegen het verwachte aanbod. De totale vraag naar nieuwkomers kan daarbij voortvloeien uit een toenemende werkgelegenheid ('uitbreidingsvraag') en uit de terugtreding van arbeidskrachten in verband met pensionering e.d. of vanwege de opvoeding en verzorging van de kinderen ('vervangingsvraag'). Het aanbod bestaat enerzijds uit de instroom van schoolverlaters op de arbeidsmarkt en anderzijds uit de (kortdurig) werklozen aan het begin van de prognoseperiode. Een ongunstige typering van de toekomstige arbeidsmarktsituatie hoeft echter niet direct te betekenen dat er in de toekomst sprake zal zijn van een toenemende werkloosheid voor de desbetreffende opleidingscategorie, aangezien schoolverlaters vaak in meer of mindere mate kunnen uitwijken naar andere beroepsdomeinen, al dan niet op hun eigen opleidingsniveau. De marktpositie van arbeidskrachten met een bepaalde opleiding is derhalve ook afhankelijk van de uitwijkmogelijkheden op de arbeidsmarkt. Aan het slot van dit hoofdstuk wordt deze risico-factor, op basis van een indicatie van de uitwijkmogelijkheden naar beroepen op een aansluitend of hoger functieniveau, nader beschouwd.

Tabel 1.7. Werkloosheid per opleidingscategorie april 1991 (bemiddelingsbestand zonder baan)

Lager

algemeen

Uitgebreid lager algemeen/economisch

- technisch/agrarisch

Middelbaar

algemeen

- verzorgend

Hoger

- technisch/agrarisch economisch verzorgend

Totaal (incl. overige opleidingen en opleiding onbekend) 
Tabel 1.7. geeft een beeld van de werkloosheid per opleidingscategorie in april 1991. Bij de cijfers in de tabel moet wel worden bedacht dat deze zijn bepaald met behulp van de inschrijvingsaantallen bij de arbeidsbureaus ${ }^{3}$ "waarvan de onnauwkeurigheid als gevolg van bestandsvervuiling algemeen bekend is. Het officiële werkloosheidscijfer ligt beduidend lager dan de hier gebruikte aantallen ingeschreven werklozen. Op het gewenste aggregatieniveau van opleidingscategorieën zijn echter helaas onvoldoende gegevens beschikbaar van de werkelijke aantallen werklozen. De in tabel 1.7. gepresenteerde percentages geven evenwel naar verwachting een goede indicatie van de relatieve ernst van de werkloosheid voor de onderscheiden opleidingscategorieën.

De werkloosheid is het hoogst voor de lager opgeleiden. Ook de vitgebreid lager opgeleiden kampen met een relatief hoge werkloosheid. Met name onder degenen met een opleiding in de algemeen/economische of de verzorgende richting op dit (LBO) opleidingsniveau is er sprake van hoge werkloosheid. Ook de middelbaar algemeen opgeleiden (HAVO/VWO) zijn relatief vaak werkloos. In combinatie met de reeds eerder genoemde 'specialiseringtrend', kan wellicht worden geconcludeerd dat een algemeen vormende opleiding op de huidige arbeidsmarkt vaak niet meer voldoende is voor de uitoefening van een beroep. De werkloosheidspercentages voor de overige opleidingscategorieën zijn laag te noemen, met uitzondering van de categorie hoger verzorgend.

De huidige situatie op de arbeidsmarkt kan in de toekomst veranderen als gevolg van ontwikkelingen in de werkgelegenheidsstructuur en/of veranderingen in de omvang of de structuur van het arbeidsaanbod. Het is daarom zinvol na te gaan wat de perspectieven op de arbeidsmarkt op middellange termijn zijn. Zoals eerder is opgemerkt, zijn deze perspectieven het resultaat van een confrontatie over de prognoseperiode van de behoefte aan nieuwkomers op de arbeidsmarkt (rekening houdend met uitbreidings- en vervangingsvraag) met de uitstroom uit het onderwijs, (vermeerderen met de werkloosheid in het basisjaar van de prognose). De verwachte arbeidsmarktperspectieven voor de 11 onderscheiden opleidingscategorieön worden gepresenteerd in tabel 1.8 .

Uit tabel 1.8. blijkt dat een slecht arbeidsmarktperspectief wordt verwacht voor de laagst opgeleiden. Het op dit moment al hoge werkloosheidspercentage onder deze groep 'ongeschoolden' zal naar verwachting ook in de toekomst nog hoog blijven. Bovendien wordt de toekomstige situatie voor nieuwkomers op de arbeidsmarkt als slecht getypeerd voor middelbaar algemeen en middelbaar technisch/agrarisch ${ }^{4}$ opgeleiden. Voor deze laatstgenoemde groep is dit een opmerkelijk verschil met de huidige arbeidsmarktsituatie, zoals die in tabel 1.7. werd geschetst. De arbeidsmarktperspectieven zijn verder naar verwachting slecht voor de (zeer heterogene categorie) hoger verzorgend opgeleiden.

3. Dit betreft het Bemiddelingsbestand Zonder Baan op basis van de ISVA-bestanden van de Arbeidsvoorzieningsorganisatie.

4. Deze slechte arbeidsmarkttypering wordt daarbij met name veroorzaakt door de verwachte toekomstige situatie op de arbeidsmarkt voor middelbaar agrarisch opgeleiden. 
Tabel 1.8. Toekomstig arbeidsmarktperspectief per opleidingscategorie 1989-1994

\section{Opleidingscategorie}

toekomstig arbeidsmarktperspectief ${ }^{\circ}$

\begin{tabular}{|c|c|c|}
\hline $\begin{array}{l}\text { Lager } \\
\text { - }\end{array}$ & algemeen & slecht \\
\hline Uitget & $\begin{array}{l}\text { reid lager } \\
\text { algemeen/economisch } \\
\text { technisch/agrarisch } \\
\text { verzorgend }\end{array}$ & $\begin{array}{l}\text { goed } \\
\text { matig } \\
\text { goed }\end{array}$ \\
\hline $\begin{array}{l}\text { Midde } \\
\text { - } \\
\text { - } \\
\text { - }\end{array}$ & $\begin{array}{l}\text { Ibaar } \\
\text { algemeen } \\
\text { technisch/agrarisch } \\
\text { economisch } \\
\text { verzorgend }\end{array}$ & $\begin{array}{l}\text { slecht } \\
\text { slecht } \\
\text { goed } \\
\text { goed }\end{array}$ \\
\hline $\begin{array}{l}\text { Hoger } \\
- \\
-\end{array}$ & $\begin{array}{l}\text { technisch/agrarisch } \\
\text { economisch } \\
\text { verzorgend }\end{array}$ & $\begin{array}{l}\text { goed } \\
\text { redelijk } \\
\text { slecht }\end{array}$ \\
\hline - & $\begin{array}{l}\text { Hierbij moet worden opgemerkt dat de in deze tabel gegeven typeringen niet } \\
\text { toepassing hoeven te zijn op de verschillende onderliggende opleidingstypen. } \\
\text { bij de opleidingscategorie middelbaar technisch/agrarisch. }\end{array}$ & $\begin{array}{l}\text { Doodzakelijkerwijs van } \\
\text { Dit speelt bijvoorbeeld }\end{array}$ \\
\hline
\end{tabular}

Bron: ROA

Een gunstige arbeidsmarkt wordt verwacht voor algemeen/economisch en verzorgend opgeleiden op het uitgebreid lagere niveau, de economisch en verzorgend opgeleiden op middelbaar niveau en de technisch/agrarisch opgeleiden op het hogere niveau. Voor de twee eerstgenoemde opleidingen op uitgebreid lager niveau betekent deze typering van de toekomstige arbeidsmarktsituatie eveneens een omslag ten opzichte van de huidige situatie. Tenslotte kan worden vermeld dat voor de uitgebreid lager opgeleiden in de technisch/ agrarische richtingen en voor de hoger economisch opgeleiden de toekomstige arbeidsmarktsituatie naar verwachting respectievelijk als matig en redelijk kan worden getypeerd.

Bij een vergelijking tussen de bovenstaande resultaten en de prognoses van het CPB (zie Van Opstal, 1989$)^{5}$ is een redelijke mate van overeenstemming te constateren. Zo komt bijvoorbeeld het verwachte beeld overeen voor de uitgebreid lager algemeen/economische opleidingen, de middelbaar algemene opleidingen en voor de opleidingscategorieën op hoger niveau. Opvallende verschillen treden op bij de opleidingen technisch/agrarisch op uitgebreid lager en middelbaar niveau en de economische opleidingen op middelbaar en hoger niveau. Het CPB verwacht voor 1994 een krappe arbeidsmarkt voor de middelbaar technisch/agrarisch

5. Daarbij is uitgegaan van de CPB-prognoses van de arbeidsmarktsituatie in het jaar 1994, als onderdeel van de lange-termijnramingen voor het jaar 2000 . 
opgeleiden en een ruime arbeidsmarkt voor de uitgebreid lager technisch/agrarisch geschoolden. Tabel 1.8. geeft voor deze twee opleidingscategorieën echter een tegengestelde tendens aan. Bovendien laat deze tabel zien dat door ons voor de economische opleidingen op middelbaar niveau een relatief beter arbeidsmarktperspectief wordt verwacht dan voor hogere economische opleidingen, terwijl het CPB ook hier het omgekeerde beeld verwacht. Mogelijk houdt het CPB meer rekening met het optreden van verdringings- of substitutie-processen op de arbeidsmarkt, waardoor het verwachte aanbodoverschot aan respectievelijk middelbaar technisch/agrarisch en hoger economisch opgeleiden geringer wordt. Het is echter de vraag of de 'perspectieven' op de arbeidsmarkt daarom ook gunstiger moeten worden ingeschat, aangezien degenen met deze opleidingsachtergrond in dat geval actief zullen moeten zijn in functies van een relatief laag niveau.

Dit (potentiële) uitwijkgedrag varieert van opleiding tot opleiding. Sommige opleidingen hebben een vrij breed georiënteerd karakter, terwijl andere opleidingen zich richten op specifieke segmenten van de arbeidsmarkt. De marktpositie van een opleidingscategorie wordt ook door dit flexibiliteitspotentieel bepaald ${ }^{6}$. Daarbij is het tevens van belang of de uitwijkmogelijkheden betrekking hebben op functies op het niveau van de gevolgde opleiding of dat deze flexibiliteit voornamelijk betrekking heeft op banen met een te laag functieniveau vergeleken met het niveau van de opleiding. In het algemeen kan worden geconcludeerd dat voor de algemeen vormende opleidingsrichtingen, de uitwijkmogelijkheden naar functies die qua niveau aansluiten op de gevolgde opleiding, relatief groot zijn. Opvallend is dat ook de technisch/agrarisch opgeleiden in relatief veel beroepen terecht komen ${ }^{7}$. De economisch/administratieve opleidingen kennen eveneens een redelijk hoge flexibiliteit. De uitwijkmogelijkheden van verzorgend opgeleiden zijn daarentegen relatief laag. Het risico van een dergelijke opleidingskeuze is derhalve groter dan voor een andersoortige opleiding.

6. In hoofdstuk 3 wordt bij de bepaling van de marktpositie van opleidingen ook aandacht besteed aan de mate van onderbenutting van de werkenden. Dit aspect wordt hier buiten beschouwing gelaten.

7. Mogelijk wordt de flexibiliteitsmaat hier echter vertekend door de oververtegenwoordiging van technische beroepsgroepen in de CBS-3-digit-beroepenclassificatie. 


\section{STROMEN OP DE ARBEIDSMARKT}

\subsection{Inleiding}

Arbeidsmarktprognoses kunnen worden opgesteld voor de situatie op een bepaald toekomstig tijdstip en voor een bepaalde toekomstige periode. De laatstgenoemde 'stroomcijfer' aanpak maakt het mogelijk op inzichtelijke wijze de verschillende onderliggende vraag- en aanbodfactoren, zoals deze zich over de gehele prognoseperiode naar verwachting zullen ontwikkelen, in beeld te brengen. Voor deze opzet is binnen het ROA-informatiesysteem onderwijsarbeidsmarkt gekozen. De prognoses hebben daarbij betrekking op beroepen en opleidingen verdeeld over de volle breedte van de arbeidsmarkt.

De beroepen zijn ingedeeld volgens de ROA-beroepenclassificatie 1990 (zie Dekker, De Grip en Van de Loo, 1990), aangezien deze classificatie beter rekening houdt met bestaande segmenten op de arbeidsmarkt dan de huidige CBS-beroepenclassificatie (CBS, 1984) ${ }^{\circ}$. De ROA-beroepenclassificatie is op basis van een viercijferige code gestructureerd. De eerste digit verwijst naar het opleidings(richting)profiel van de werkenden in een beroepsklasse, terwijl de tweede digit de branche aangeeft waarin de beroepsbeoefenaren werkzaam zijn. De derde digit geeft het (mediane) opleidingsniveau van de werkenden aan, waarbij een onderscheid wordt gemaakt tussen respectievelijk 'lager', 'middelbaar' en 'hoger' opgeleiden. De vierde digit geeft tenslotte slechts een volgnummer aan. In totaal worden op deze manier 93 beroepsklassen onderscheiden die (kunnen) worden samengevoegd tot 48 beroepssegmenten, 27 beroepstakken en 10 beroepssectoren. De opleidingen zijn ingedeeld in 49 opleidingstypen, gebaseerd op een clustering van de 3-digit-opleidingen van de CBS-Standaard Onderwijs Indeling (CBS, 1989).

Aan de vraagzijde van de arbeidsmarkt wordt een onderscheid gemaakt tussen enerzijds de verwachte uitbreidingsvraag op grond van de ontwikkeling van de werkgelegenheid voor een bepaalde beroepsklasse of een bepaald opleidingstype en anderzijds de verwachte vervangingsvraag vanwege pensionering, (tijdelijke) terugtrekking van de arbeidsmarkt, beroepsmobiliteit e.d. De uitbreidingsvraag en de vervangingsvraag geven te zamen het aantal voor de prognoseperiode verwachte baanopeningen. Daartegenover staan aan de aanbodzijde van de arbeidsmarkt de verwachte toekomstige instroom van schoolverlaters en het aanbod van (kortdurig) werklozen. De in dit rapport gepresenteerde prognoses hebben betrekking op de periode 1989-1994. Figuur 2.1. geeft een overzicht van de onderlinge relaties tussen de verschillende vraag- en aanbodstromen op de arbeidsmarkt, waarvoor in het informatiesysteem onderwijs-arbeidsmarkt van het ROA middellange termijn prognoses worden opgesteld.

8. De ROA-beroepenclassificatie is gebaseerd op een clustering van de CBS 3-digit beroepsgroepen, waarbij het clusteringscriterium de opleidingsachtergrond van de werkenden is. 
Figuur 2.1. Stromen op de arbeidsmarkt

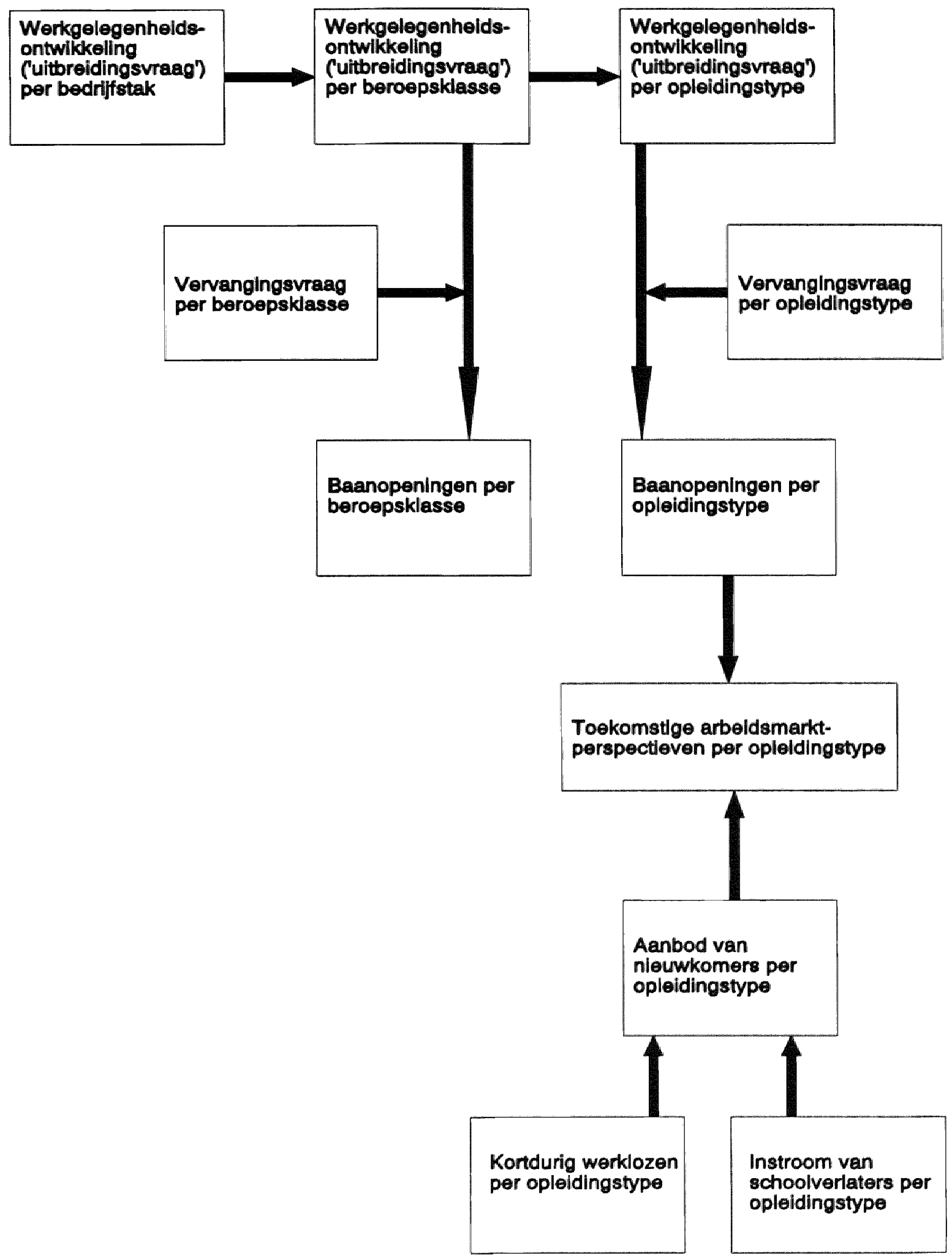


Het uitgangspunt voor de prognoses van de toekomstige uitbreidingsvraag per beroepsklasse wordt gevormd door de prognoses van het aantal werkzame personen voor 14 bedrijfstakken van het CPB. Met behulp van het 'ROA-beroepenmodel' wordt de sectorale werkgelegenheidsontwikkeling eerst verdeeld naar beroepssegment en daarna naar beroepsklasse. In dit model wordt de beroepenstructuur binnen bedrijfstakken verklaard uit de technologische ontwikkeling, conjuncturele factoren en structurele (trendleffecten. Op deze wijze kan de verwachte uitbreidingsvraag per beroepsklasse in de periode 1989-1994 worden bepaald. Voor een meer uitgebreide beschrijving van de gehanteerde methodiek wordt verwezen naar Dekker, De Grip, Berendsen, Wieling en Willems (1992).

De vervangingsvraag per beroepsklasse wordt bepaald door de in de analyseperiode waargenomen geslachts- en leeftijdspecifieke netto verloopcoëfficiënten per beroepsklasse te 'extrapoleren' naar de toekomst. Daarbij wordt gecorrigeerd voor de conjuncturele component in het verloop in de analyseperiode (de uitstroom van werkenden naar het werklozenbestand). Bovendien vindt een correctie plaats voor de verwachte ontwikkeling van de participatiegraad per geslacht en leeftijdscategorie (zie Willems en De Grip, 1990).

De verwachte uitbreidingsvraag per opleidingstype wordt bepaald met behulp van het 'ROAopleidingenmodel'. Dit model analyseert de ontwikkeling van de opleidingenstructuur binnen beroepen op basis van zowel economische factoren als trendeffecten. De impliciet in het model opgenomen technologische ontwikkeling vormt een verklaringsgrond voor de toename (of afnamel van het voor de uitoefening van een bepaald beroep vereiste opleidingsniveau. Men spreekt in dit verband wel van respectievelijk upgrading en downgrading. De daadwerkelijk op de arbeidsmarkt gevraagde opleiding wordt daarnaast beïnvloed door de relatieve schaarste van de verschillende opleidingen. Al dan niet via een aanpassing van de relatieve beloning zal een toenemend aanbod van een bepaalde opleiding op grond van dit mechanisme ook leiden tot een toenemende vraag naar de desbetreffende opleiding (zie Dekker, De Grip, Berendsen, Wieling en Willems, 1992).

De prognose van de uitbreidingsvraag per opleidingstype wordt aangevuld met een prognose van de toekomstige vervangingsvraag. De laatste prognose wordt op soortgelijke wijze bepaald als de vervangingsvraag per beroepsklasse. Een belangrijk verschil dat zich daarbij voordoet is dat de beroepsmobiliteit niet van invloed is op de vervangingsvraag naar opleidingstype. Gemiddeld genomen is de vervangingsvraag per opleidingstype derhalve kleiner dan de vervangingsvraag per beroepsklasse (zie Willems en De Grip, 1990).

De aanbodprognose per opleidingstype wordt opgesteld met behulp van diverse prognoses van het Ministerie van Onderwijs en Wetenschappen betreffende het reguliere voltijdonderwijs, en uiteenlopende gegevens over de verwachte uitstroom uit het regulier deeltijdonderwijs en het niet-regulier onderwijs (zie Berendsen, Dekker, De Grip en Van de Loo, 1992). Naast de op deze wijze opgestelde prognoses van de instroom van schoolverlaters op de arbeidsmarkt in de periode 1989-1994, bestaat het aanbod van nieuwkomers uit het aantal kortdurig werklozen aan het begin van deze periode. Tenslotte kunnen op basis van een confrontatie van de vraag- 
en aanbodprognoses uitspraken worden gedaan over de toekomstige arbeidsmarktperspectieven per opleidingstype.

In het vervolg van dit hoofdstuk worden de verschillende stromen op de arbeidsmarkt die de 'bouwstenen' vormen van de arbeidsmarktprognoses besproken. Eerst zal de verwachte uitbreidingsvraag van zowel beroepsklassen als opleidingstypen aan bod komen. Vervolgens komt de verwachte vervangingsvraag van beroepsklassen en opleidingstypen aan de orde. Bij zowel de uitbreidings- als de vervangingsvraag wordt daarbiij slechts ingegaan op de beroepsklassen on opleidingstypen met de (absoluut en relatief gezien) hoogste en laagste vraag naar nieuwkomers. Tenslotte worden de prognoses van de instroom van schoolverlaters op de arbeidsmarkt gepresenteerd ${ }^{2}$. Ook hier komen slechts de opleidingstypen aan de orde met de labsoluut en relatief gezien) hoogste en laagste instroom van schoolverlaters op de arbeidsmarkt.

\subsection{Uitbreidingsvraag}

\section{Beroepen}

Tabel 2.1. geeft aan welke beroepsklassen het meest profiteren van de verwachte werkgelegenheidsgroei in de periode 1989-1994. Het bovenste gedeelte van de tabel geeft aan voor welke tien beroepsklassen de werkgelegerıheidsgroei absoluut gezien het sterkst stijgt. In het onderste gedeelte worden de beroepsklassen met de relatief grootste verwachte groei van het aantal werkenden gepresenteerd. De werkgelegenheidstoename wordt daarbij uitgedrukt in procenten van het aantal werkzame personen in de desbetreffende beroepsklasse in 1989. Opgemerkt kan worden dat in sommige gevallen voor de beroepsklassen binnen één beroepssegment dezelfde relatieve verwachte groei is geprognosticeerd. Dit is het gevolg van de gehanteerde methodiek, waarbij de tot eenzelfde beroepssegment behorende beroepsklassen alle hetzelfde groeipercentage krijgen, indien er geen significante verschillen optreden in de ontwikkeling van de werkgelegenheidsaandelen van de beroepsklassen binnen dit beroepssegment. Doordat het beroepssegment hier in feite de plaats inneemt van de onderliggende beroepsklassen, zijn in de tabel met beroepsklassen met een relatief hoge werkgelegenheidsgroei meer dan tien beroepsklassen opgenomen.

In totaal wordt voor 60 van de 93 onderscheiden beroepsklassen een stijging van het aantal werkzame personen in de periode 1989-1994 verwacht. De verwachte absolute uitbreidingsvraag is het grootst voor de 'directeuren, bedrijfsleiders, leidinggevenden industrie'. Het aantal werkenden in deze beroepsklasse neemt naar verwachting in vijf jaar met maar liefst ruim 110.000 toe. De beroepsklasse 'winkel-, straat en marktverkopers, demonstrateurs' en 'hogere leidinggevenden' kennen een verwachte toekomstige uitbreidingsvraag van respectievelijk ruim 83.000 en ruim 49.000 werkenden.

9. Het aanbod van kortdurig werklozen komt in dit hoofdstuk niet expliciet aan de orde. Wel wordt in hoofdstuk 3 ingegaan op de werkloosheid in 1991, waarbij overigens geen onderscheid wordt gemaakt tussen kort- en langdurig werklozen. 
Tabel 2.1. Beroepsklassen met de hoogste uitbreidingswraag 1989-1994 labsolute aantallen en als percentage van het aantal werkenden in 1989)

ROA- beroepsklasse

code

uitbreidingsvraag

aantal

\section{Absoluut}

3021 directeuren, bedrijfsleiders, leidinggevenden industrie

6211 winkel-, straat- en marktverkopers, demonstrateurs

6031 hogere leidinggevenden

8212 kinder-, gezins-, bejaardenverzorgenden e.a. verzorgend personeel

8211 portiers, schoonmaak- e.a. lager dienstverlenend personeel

3031 beta-onderzoekers, technische vakspecialisten

4211 conducteurs, chauffeurs e.a. transportmiddelenbestuurders

6131 systeemanalisten, programmeurs en -beheerders

6221 winkeliers e.a. detail- en groothandelaren

19.700

7021 auteurs, journalisten, nieuwslezers, presentatoren

\section{Relatief}

7021 auteurs, journalisten, nieuwslezers, presentatoren

19.700

6031 hogere leidinggevenden

49.300

3031 beta-onderzoekers, technische valkspecialisten

$27.900 \quad 53$

3021 directeuren, bedrijfsleiders, leidinggevenden industrie

110.600

3024 technische analisten, amanuenses

3023 technische tekenaars

10.300

12.600

3022 technische en medische vertegenwoordigers

2.300

8212 kinder-, gezins;, bejaardenverzorgenden e.a. verzorgend personeel

49.200

3921 bouwkundige technici, opzichters, werkvoorbereiders

6.300

9121 politie-, brandweer- en bewakingspersoneel

13.300

6211 winkel-, straat- en marktverkopers, demonstrateurs

83.100

Bron: ROA

Vanzelfsprekend geldt voor de beroepsklassen waarin veel mensen werken dat een kleine procentuele groei van de werkgelegenheid reeds voldoende is om voor te komen in de lijst van beroepsklassen met een absoluut hoge uitbreidingsvraag, terwijl omgekeerd 'kleine' beroepsklassen meestal een in absolute termen lage groei te zien geven. Om een beeld te krijgen van het belang van de uitbreidingsvraag van de verschillende beroepsklassen voor de totale werkgelegenheidsgroei, is een rangordening naar absolute aantallen echter uiterst informatief. De relatieve rangorde geeft daarentegen meer inzicht in de relatieve verschillen in de verwachte toekomstige uitbreidingsvraag.

Voor de beroepsklasse 'auteurs, journalisten, nieuwslezers, presentatoren' wordt het hoogste uitbreidingsvraagpercentage verwacht. In de periode 1989-1994 zal het aantal arbeidsplaatsen met maar liefst $60 \%$ stijgen. Verder is de verwachte groei van de werkgelegenheid voor de 'hogere leidinggevenden' en de 'bèta-onderzoekers, technische vakspecialisten' opvallend. Hoewel de beroepsklasse 'systeemanalisten, -programmeurs en beheerders' nog tot de grootste 
groeiberoepen behoort, valt op dat deze beroepsklasse bij lange na niet meer de beroepsklasse is met relatief gezien de hoogste groeiverwachting.

In tabel 2.2. wordt aangegeven voor welke beroepsklassen de werkgelegenheid naar verwachting het sterkst zal dalen. In totaal zijn er 33 beroepsklassen waarvoor een daling van het aantal werkenden wordt verwacht. Het blijkt dat de hoogste krimpcijfers in het algemeen gematigder zijn dan de hoogste groeicijfers. De grootste absolute daling van het aantal werkenden wordt verwacht voor de beroepsklasse 'uitvoerend agrarisch personeel, bosarbeiders'. Relatief gezien kennen de 'auto-, motor- en bromfietsmonteurs' naar verwachting de grootste werkgelegenheidsdaling.

Tabel 2.2. Beroepsklassen met de laagste uitbreidingsvraag 1989-1994 labsolute aantallen en als percentage van het aantal werkenden in 1989)

ROA- beroepsklasse

code

uitbreidingsvraag

aantal

$\%$

\section{Absoluut}

2011 uitvoerend agrarisch personeel, bosarbeiders

$-23.500$

2012 zelfstandige agrariërs, boswachters

$-21.100$

3312 houtbewerkers, timmerlieden

$-19.500$

3915 overige bouwvaklieden, (spoor/weg- en reinigingswerkers

$-19.100$

3621 auto-, motor- en bromfietsmonteurs

$-12.900$

3911 metselaars, tegelzetters, straatmakers, stukadoors

$-12.100$

3914 loodgieters sanitair-installateurs en -reparateurs

$-11.300$

3615 onderhoudsmonteurs, fietsen - en instrumentmakers

$-9.400$

3613 lassers, constructiewerkers, edelmetaalsmeden

$-9.200$

\section{Relatief}

3621 auto-, motor- en bromfietsmonteurs

$-12.900$

3915 overige bouwvaklieden, (spoor)weg-en reinigingswerkers

$-19.100$

3911 metselaars, tegelzetters, straatmakers, stukadoors

$-12.100$

3914 loodgieters, sanitair-installateurs en -reparateurs

$-11.300$

3913 huis-, scheeps- en constructieschilders

$-7.800$

3912 betonwerkers, dakdekkers, isoleerders, glaszetters

$-5.500$

6331 leden en leidinggevenden openbaar bestuur, beleidsambtenaren

$-5.900$

3731 hogere electrotechnici

$-3.800$

3631 hogere werktuigkundigen

$-2.800$

$-16$

3312 houtbewerkers, timmerlieden

$-19.500$

3613 lassers, constructiewerkers, edelmetaalsmeden

$-9.200$

2011 uitvoerend agrarisch personeel, bosarbeiders

$-23.500$

2012 zelfstandige agrariërs, boswachters

$-21.100$

3811 produktiepersoneel bouwmaterialen-, glas- en aardewerkindustrie

$-4.000$

3612 machinale metaalbewerkers

$-5.100$

3611 delfstoffen(be)/werkers, metaalvervaardigers

$-1.700$ 
Opvallend is verder dat zowel de in absolute zin als de in relatieve zin sterke dalers in hoofdzaak bestaan uit technische, ambachts- en industrieberoepen, waarbij het mediane opleidingsniveau van de werkenden relatief laag is. Daarnaast kan worden opgemerkt dat tot de beroepsklassen met een relatief sterk dalende werkgelegenheid ook een drietal beroepsklassen met hoger opgeleiden behoort. Het gaat hier echter om in absolute zin 'kleine' beroepsklassen.

\title{
Opleidingen
}

In tabel 2.3. worden de tien opleidingstypen gepresenteerd met de hoogste verwachte groei van het aantal werkenden in de periode 1989-1994. Ook hier is een onderscheid gemaakt tussen een in absolute zin en een in relatieve zin sterk stijgende werkgelegenheid. De relatieve werkgelegenheidsontwikkeling wordt daarbij uitgedrukt als percentage van (de prognose van) het aantal werkenden in 1989. Aangezien voor het jaar 1989 geen feitelijke opleidingsgegevens van de werkzame bevolking beschikbaar zijn is de absolute werkgelegenheidsontwikkeling per opleidingstype bepaald door de verwachte relatieve ontwikkeling in de periode 1989-1994 te relateren aan de (wel beschikbare) werkgelegenheidscijfers van 1990.

Tabel 2.3. Opleidingstypen met de hoogste uitbreidingsvraag 1989-1994 labsolute aantallen en als percentage van het aantal werkenden in 1989)

Opleidingstype

uitbreidingsvraag

aantal

\begin{abstract}
Absoluut
MBO Economisch-Administratief

MBO Verzorgend

HBO Economisch-Administratief

HBO Technisch

MBO Verpleging \& Ziekenverzorging

MBO Politie \& Defensie

HBO Sociaal-Cultureel

Wo Technisch

HBO Technische Bedrijfskunde

$M B O$ Verzorgend

WO Wis-/Natuurkunde

Wo Technisch

LBO Beveiliging \& Bewaking

HBO Technisch

HBO Technisch Laboratorium

MBO Politie \& Defensie

119.200

76.800

47.700

47.300

36.300

27.200

24.500

21.200

20.500

18.800

76.800

12.600

18.800

1.700

27.200

5.900

21.200

36.300 
De werkgelegenheid neemt naar verwachting toe voor maar liefst 42 van de 49 onderscheiden opleidingstypen. In de lijst met opleidingstypen met een relatief hoge uitbreidingsvraag zijn met name de opleidingen op HBO-niveau sterk vertegenwoordigd. Ook is het opvallend dat voor veel technisch georiënteerde opleidingen een gunstige werkgelegenheidsontwikkeling wordt verwacht.

Het opleidingstype 'HBO Technische Bedrijfskunde' heeft naar verwachting de relatiof hoogste uitbreidingsvraag in de periode 1989-1994. Het betreft echter een 'klein' opleidingstype. De verzorgende opleiding op MBO-niveau heeft met $32 \%$ eveneens een relatief hoge verwachte groei van de werkgelegenheid. Verder is met name de verwachte hoge toekomstige uitbreidingsvraag voor het opleidingstype 'HBO Sociaal-Cultureel' opmerkelijk. Deze grote werkgelegenheidstoename kan worden teruggevoerd op de verwachte ontwikkeling van de beroepenstructuur en daarbij met name de werkgelegenheidsgroei van de beroepsklasse 'auteurs, journalisten, nieuwslezers, presentatoren'.

Tabel 2.4. Opleidingstypen met de laagste uitbreidingsvraag 1989-1994 (absolute aantallen en als percentage van het aantal werkenden in 1989)

Opleidingstype

uitbreidingsvraag

aantal
Absoluut
Basisonderwijs
LBO Technisch
MBO Agrarisch
HBO Onderwijs
LBO Agrarisch
WO Onderwijs
WO Kunst
HBO Bestuurlijk
MBO Technisch Laboratorium
WO Agrarisch

Relatief

MBO Agrarisch

Basisonderwijs

LBO Technisch

WO Onderwijs

Wo Kunst

LBO Agrarisch

HBO Onderwijs

HBO Bestuurlijk

MBO Horeca \& Kappers

Bovenbouw HAVONWO
$-80.300$

$-34.700$

$-16.900$

$-4.300$

$-2.800$

$-800$

$-200$

100

400

400

$-16.900$

$-14$

$-80.300$

$-34.700$

$-800$

$-200$

$-2.800$

$-4.300$

100

600

7.400
$-12$

$-6$

$-14$

$-2$

$-3$

$-3$

$-3$

0

3

5

Bron: ROA 
Tabel 2.4. geeft aan voor welke opleidingstypen een lage uitbreidingsvraag wordt verwacht. Het blijkt dat voor slechts 7 opleidingstypen de werkgelegenheid in de periode 1989-1994 zal afnemen. De grootste werkgelegenheidsdalingen doen zich voor bij 'MBO Agrarisch', 'Basisonderwijs' en 'LBO Technisch'. Het aantal werkenden neemt voor deze drie opleidingstypen met respectievelijk $14 \%, 12 \%$ en $6 \%$ af. Voor het basisonderwijs komt dit neer op een verlies van maar liefst ruim 80.000 arbeidsplaatsen.

Tot de opleidingstypen met een (relatief) lage uitbreidingsvraag behoren ook enkele hogere opleidingen. Zo wordt voor de lerarenopleidingen ('WO Onderwijs' en 'HBO Onderwijs') een werkgelegenheidsdaling verwacht. Binnen deze opleidingen kan het beeld per studierichting evenwel zeer verschillend zijn (zie bijvoorbeeld De Voogd en Olieman, 1990). Op basis van specifieke prognoses wordt overigens voor leraren in het basisonderwijs een werkgelegenheidstoename verwacht (zie IVA, 1992). Verder is de verwachte stabiele werkgelegenheid voor 'HBO Bestuurlijk' opvallend, aangezien de andere (HEAO)-studierichtingen wel een hoge groei te zien geven. Overigens daalde het aandeel van deze richting binnen het $H E A O$ al in de periode 1979-1985. De verwachting is derhalve dat deze dalende trend zich zal voortzetten.

\subsection{Vervangingsvraag}

\section{Beroepen}

Naast de werkgelegenheidsontwikkeling is de vervangingsvraag als gevolg van pensionering, beroepsklassemobiliteit, e.d. vaak van groot belang voor het aantal baanopeningen in een beroepsklasse. Tabel 2.5. en 2.6. geven achtereenvolgens een beeld van de tien beroepsklassen met de naar verwachting hoogste en laagste vervangingsvraag in de periode 1989-1994. De gemiddelde verwachte vervangingsvraag per beroepsklasse bedraagt $11 \%$ van het aantal werkenden in 1989.

Voor de beroepsklasse 'winkel-, straat- en marktverkopers, demonstrateurs' wordt de (absoluut) grootste vervangingsvraag verwacht. In vijf jaar tijd zullen in deze beroepsklasse maar liefst bijna 70.000 arbeidskrachten door nieuwkomers moeten worden vervangen. Voor de beroepsklassen 'commercieel-administratieve employées' en 'boekhoudkundige, belasting-, loket- en bankemployées' bedraagt de verwachte vervangingsvraag respectievelijk ruim 37.000 en ruim 32.000 werkenden.

De beroepsklassen 'personeels- en beroepenspecialisten, arbeidsbemiddelaars' en 'leerlingverpleegkundigen, zieken- en kraamverzorgenden' hebben met $21 \%$ van het aantal werkenden in 1989 naar verwachting de grootste relatieve vervangingsvraag. Verder is het opvallend dat voor de beroepsklassen waarin relatief veel vrouwen werkzaam zijn, zoals de reeds genoemde 'leerling-verpleegkundigen, zieken- en kraamverzorgenden' en 'kleding- e.a. textiel- en bontproduktenmakers' en 'dokters-, tandarts- en dierenartsassistenten', een hoge (relatieve) vervangingsvraag wordt verwacht. Dit wordt vanzelfsprekend veroorzaakt door het feit dat veel vrouwen zich op relatief jonge leeftijd van de arbeidsmarkt terugtrekken in verband met de 
verzorging van de kinderen. Ook de hoge vervangingsvraag van de pastorale beroepen, waarin veel ouderen werkzaam zijn, is opvallend ${ }^{10}$.

Tabel 2.5. Beroepsklassen met de hoogste vervangingsvraag 1989-1994 (absolute aantallen en als percentage van het aantal werkenden in 1989)

ROA- beroepsklasse

code

vervangingsvraag

aantal $\%$

\section{Absoluut}

6211 winkel-, straat-, en marktverkopers, demonstrateurs

6125 commercieel-administratieve employées

$68.500 \quad 18$

6124 boekhoudkundige, belasting-, loket-en bankemployées

37.400

11

8211 portiers, schoonmaak- e.a. lager dienstverlenend personeel

32.200

9

4211 conducteurs, chauffeurs e.a. transportmiddelenbestuurders

29.500

25.000

3021 directeuren, bedrijfsleiders, leidinggevenden industrie

24.000

12

2011 uitvoerend agrarisch personeel, bosarbeiders

22.900

5022 leerling-verpleegkundigen, zieken- en lkraamverzorgenden

22.400

21.800

8111 koks, kelners e.a. keuken- en serveerpersoneel

18.400

2012 zelfstandige agrariërs, boswachters

\section{Relatief}

7032 personeels- en beroepenspecialisten, arbeidsbemiddelaars

5022 leerling-verpleegkundigen, zieken- en kraamverzorgenden

1131 taal- en letterkundigen, vertalers, tolken

1.700

1331 beeldende en uitvoerende kunstenaars

$7.100 \quad 19$

1231 pastorale beroepen

$2.200 \quad 19$

6211 winkel-, straat- en marktverkopers, demonstrateurs

68.500

3213 kleding-, e.a. textiel- en bontproduktenmakers

4.900

4112 matrozen e.a. scheepsdek- en machinekamerpersoneel

1.100

5023 dokters-, tandarts-, dierenartsassistenten

3.900

9221 beroepsmilitairen

7.300

Bron: ROA

In tabel 2.6. komt naar voren dat tot de beroepsklassen met een lage vervangingsbehoefte een aantal technische, ambachts- en industrieberoepen op lager of middelbaar niveau behoort. Het gaat hierbij veelal om beroepsklassen met een krimpende werkgelegenheid, waarbij het verloop niet geheel wordt opgevuld. Voor de "huis-, scheeps-, en constructieschilders' wordt de relatief laagste vervangingsvraag verwacht. De verwachte vervangingsbehoefte in de periode 19891994 bedraagt voor deze beroepsklasse slechts $3 \%$ van het aantal werkenden in 1989 . Bij de lage verwachte vervangingsbehoefte van de beroepsklasse 'systeemanalisten, -programmeurs en -beheerders' speelt de relatief jonge leeftijdsopbouw in deze beroepen een belangrijke rol.

10. Voor een uitgebreide beschrijving van de relaties tussen leeftijd en geslacht en de vervangingsvraag wordt verwezen naar De Grip en Willems (1992). 
Tabel 2.6. Beroepsklassen met de laagste vervangingsvraag 1989-1994 labsolute aantallen en als percentage van het aantal werkenden in 1989)

ROA- beroepsklasse

code vervangingsvraag

aantal \%

\section{Absoluut}

3622 middelbare (scheeps)werktuigkundigen e.a. metaalkundigen

30.22 technische en medische vertegenwoordigers

3913 huis-, scheeps-en constructieschilders

5024 apothekersassistenten, opticiens, orthoptisten

0221 sportinstructeurs, officials, beroepssportlieden

3731 hogere electrotechnici

3211 produktiepersoneel textielindustrie

4121 scheepsotficieren, loodsen, walinspecteurs

5035 tandheelkundigen en tandheelkundige specialisten

4112 matrozen e.a. scheepsdek- en machinekamerpersoneel

\section{Relatief}

3913 huis-, scheeps-, en constructieschilders

3622 middelbare (scheeps)werktuigkundigen e.a. metaalkundigen

3915 overige bouwvaklieden, (spoor)weg- en reinigingswerkers

6131 systeemanalisten, -programmeurs en -beheerders

3012 machinisten bouw en industrie

7033 maatschappelijke werkers, reclasseringsambtenaren

3914 loodgieters, sanitair-installateurs en -reparateurs

3731 hogere electrotechnici

6121 administratief leidinggevenden

9121 politie-, brandweer-en bewakingsdiensten

$\begin{array}{rr}600 & 4 \\ 900 & 12 \\ 1.000 & 3 \\ 1.000 & 7 \\ 1.000 & 7 \\ 1.100 & 6 \\ 1.100 & 10 \\ 1.100 & 13 \\ 1.100 & 16 \\ 1.100 & 18\end{array}$

Bron: ROA

\section{Opleidingen}

De prognose van de vervangingsvraag per opleidingstype wordt op soortgelijke wijze gemaakt als de vervangingsvraag per beroepsklasse. In paragraaf 2.1 . is reeds gewezen op een belangrijk verschil dat zich daarbij voordoet, namelijk dat de beroepsmobiliteit niet van invloed is op de vervangingsvraag per opleidingstype. Gemiddeld genomen is de vervangingsvraag per opleidingstype met $10 \%$ van het aantal werkenden in 1989 derhalve lager dan de vervangingsvraag per beroepsklasse (zie ook Willems en De Grip, 1990).

In tabel 2.7. en 2.8. wordt aangegeven voor welke tien opleidingstypen de respectievelijk hoogste en laagste vervangingsvraag wordt verwacht. Het opleidingstype 'LBO Technisch' kent naar verwachting in absolute zin de hoogste vervangingsvraag. In de periode 1989-1994 zullen bijna 86.000 arbeidskrachten met een dergelijke opleidingsachtergrond moeten worden vervangen. Dit komt overeen met 16\% van het aantal werkenden in 1989. 
Voor het opleidingstype 'HBO Theologisch' wordt de relatief hoogste vervangingsvraag verwacht. Vanzelfsprekend hangt dit samen met de reeds gesignaleerde hoge vervangingsvraag voor de 'pastorale beroepen' waarvoor dit opleidingstype beoogt op te leiden. Bovendien valt op dat enkele opleidingen die met name door vrouwen worden gevolgd een hoge vervangingsvraag hebben. Hierop wordt in hoofdstuk 5 van dit rapport nader ingegaan.

Tabel 2.7. Opleidingstypen met de hoogste vervangingsvraag 1989-1994 (absolute aantallen en als percentage van het aantal werkenden in 1989)

Opleidingstype

vervangingsvraag

aantal
85.700

75.800

54.400

50.000

44.100

43.200

37.600

34.900

26.500

17.300

1.300

1.100

7.600

85.700

34.900

75.800

37.600

5.600

2.500

44.100
16

14

8

7

13

6

14

14

10

9

HBO Medisch Laboratorium

Bovenbouw HAVO/VWO

Bron: ROA

Uit tabel 2.8. blijkt dat de laagste relatieve vervangingsvraag wordt verwacht voor het opleidingstype 'LBO Haven \& Vervoer'. In de lijst met opleidingstypen waarvoor een lage vervangingsvraag in de periode 1989-1994 wordt verwacht, valt verder met name het grote aantal HBO-opleidingen op. Liefst vijf van de tien opleidingstypen hebben op dit opleidingsniveau betrekking. Dit hangt waarschijnlijk samen met de afgelopen jaren sterk toegenomen belangstelling voor het hoger beroepsonderwijs, waardoor een relatief groot gedeelte van de werkenden nog jong is en derhalve niet op middellange termijn zal uitstromen van de arbeidsmarkt. 
Tabel 2.8. Opleidingstypen met de laagste vervangingsvraag 1989-1994 labsolute aantallen en als percentage van het aantal werkenden in 1989)

\begin{tabular}{lcc} 
Absoluut & & \\
LBO Beveiliging \& Bewaking & 400 & 7 \\
HBO Technische Bedrijfskunde & 500 & 5 \\
HBO Politie \& Defensie & 700 & 6 \\
WO Kunst & 700 & 9 \\
LBO Haven \& Vervoer & 800 & 2 \\
WO Agrarisch & 800 & 9 \\
MBO Technisch Laboratorium & 900 & 6 \\
HBO Agrarisch & 1.000 & 6 \\
WO Theologisch & 1.000 & 11 \\
HBO Tolk \& Vertaler & 1.100 & 19 \\
Relatief & & \\
LBO Haven \& Vervoer & & \\
HBO Sociaal-Cultureel & & 2 \\
HBO Economisch-Administratief & 800 & 4 \\
WO Technisch & 3.600 & 4 \\
LBO Economisch-Administratief & 5.900 & 5 \\
WO Sociaal-Cultureel & 2.800 & 5 \\
HBO Technische Bedrijfskunde & 8.100 & 5 \\
HBO Verpleging \& Paramedisch & 3.700 & 5 \\
MBO Politie \& Defensie & 500 & 6 \\
HBO Politie \& Defensie & 4.500 & 6 \\
\hline
\end{tabular}

Bron: ROA

\subsection{Baanopeningen}

\section{Beroepen}

De totale vraag naar nieuwkomers (het aantal 'baanopeningen') in een beroepsklasse wordt bepaald door de som van de (positieve) uitbreidingsvraag en de vervangingsvraag. Daarbij kan worden opgemerkt dat gemiddeld $48 \%$ van het totaal aantal baanopeningen per beroepsklasse tot stand komt door de toename van de werkgelegenheid en de resterende $52 \%$ door de vervangingsvraag. Tabel 2.9. en 2.10. Iaten de tien beroepsklassen zien met respectievelijk de meeste en de minste baanopeningen.

Opvallend is dat voor alle beroepsklassen met naar verwachting relatief veel baanopeningen deze gunstige vraagsituatie wordt veroorzaakt door een relatief hoge uitbreidingsvraag. Dit hangt vanzelfsprekend samen met de grote dynamiek in de uitbreidingsvraag en de veel geringere variaties in de vervangingsvraag. De beroepsklasse 'winkel- straat- en marktverkopers, demonstrateurs' kent naar verwachting zowel een hoog uitbreidingsvraagpercentage als een 
hoog vervangingsvraagpercentage, resulterend in een aantal baanopeningen van $40 \%$ van de werkgelegenheid in 1989. Dit komt overeen met ruim 15.000 arbeidskrachten. Het relatief grootste aantal baanopeningen wordt verwacht voor de beroepsklasse 'acteurs, journalisten, nieuwslezers, presentatoren'. Dit hangt samen met de hoge verwachte uitbreidingsvraag in deze beroepsklasse (zie tabel 2.1.). Verder is het opvallend dat enkele technische beroepsklassen op met name middelbaar niveau een naar verwachting relatief hoog aantal baanopeningen zullen hebben.

Tabel 2.9. Beroepsklassen met de meeste baanopeningen 1989-1994 (absolute aantallen en als percentage van het aantal werkenden in 1989)

ROA- beroepsklasse

code

aantal

baanopeningen

\section{Absoluut}

6211 winkel-, straat- en marktverkopers, demonstrateurs

3021 directeuren, bedrijfsleiders, leidinggevenden industrie

8211 portiers, schoonmaak- e.a. lager dienstverlenend personeel

$151.600 \quad 40$

8212 kinder-, gezins-, bejaardenverzorgenden e.a. verzorgend personeel

34.600

40

6031 hogere leidinggevenden

4211 conducteurs, chauffeurs e.a. transportmiddelenbestuurders

76.700

32

$67.200 \quad 40$

$56.200 \quad 64$

6125 commercieel administratieve employées

52.200

$39.000 \quad 12$

8111 koks, kelners e.a. keuken- en serveerpersoneel

$36.700 \quad 23$

6124 boekhoudkundige, belasting-, loket-, en bankemployées

34.000

23

3031 béta-onderzoekers, technische vakspecialisten

33.900

Relatief

7021 auteurs, journalisten, nieuwslezers, presentatoren

24.500

74

3031 bèta-onderzoekers, technische vakspecialisten

33.900

64

6031 hogere leidinggevenden

$56.200 \quad 64$

3024 technische analisten, amanuenses

$14.900 \quad 48$

3022 technische en medische vertegenwoordigers

3.200

45

3023 technische tekenaars

6211 winkel-, straat- en marktverkopers, demonstrateurs

3021 directeuren, bedrijfsleiders, lleidinggevenden industrie

16.300

8212 kinder-, gezins-, bejaardenverzorgenden e.a. verzorgend personeel

3921 bouwkundige technici, opzichters, werkvoorbereiders

$134.600 \quad 40$

$67.200 \quad 40$

$8.800 \quad 37$

Bron: ROA

De beroepsklassen met relatief weinig verwachte baanopeningen zijn vrijwel allemaal beroepsklassen met een naar verwachting dalende werkgelegenheid. Voor deze beroepsklassen bestaat de totale vraag naar nieuwkomers uitsluitend uit de toekomstige vervangingsbehoefte. Daarom bestaat de lijst van beroepsklassen met een laag aantal baanopeningen voornamelijk uit beroepsklassen met een lage verwachte vervangingsvraag (zie tabel 2.6.). Het laagste aantal baanopeningen wordt verwacht voor de 'huis-, scheeps- en constructieschilders'. De totale vraag voor deze beroepsklasse bedraagt slechts 1.000 personen, overeenkomend met $3 \%$ van 
het aantal arbeidskrachten in 1989. Verder is er in de lijst een oververtegenwoordiging van technische, ambachts- en industrieberoepen op lager niveau.

Tabel 2.10. Beroepsklassen met de minste baanopeningen 1989-1994 (absolute aantallen en als percentage van het aantal werkenden in 1989)

ROA- beroepsklasse

code

baanopeningen

aantal

\section{Absoluut}

3913 huis-, scheeps- en constructieschilders

1.000

1.100

3

3731 hogere electrotechnici

1.100

6

4121 scheepsofficieren, loodsen, walinspecteurs

1.100

13

5035 tandheelkundigen en tandheelkundige specialisten

1.200

16

3631 hogere werktuigkundigen

4112 matrozen e.a. scheepsdek- en machinekamerpersoneel

1.300

3311 houtzagers, hout(waren)-, papier-en kartonmakers

1.400

22

3622 middelbare (scheeps)werktuigkundigen e.a. metaalkundigen

1.500

3012 machinisten bouw en industrie

1.600

3211 produktiepersoneel textielindustrie

1.700

\section{Relatief}

3913 huis-, scheeps- en constructieschilders

3915 overige bouwvaklieden, (spoor)weg- en reinigingswerkers

3012 machinisten bouw en industrie

3914 loodgieters. sanitair-installateurs en -reparateurs

3731 hogere electrotechnici

6121 administratief leidinggevenden

3312 houtbewerkers, timmerlieden

3631 hogere werktuigkundigen

1321 fotografen, filmers, vormgevers, etaleurs

3112 (zelfstandige) bakkers e.a. (industrieel) bakkerijpersoneel

\section{3}

5

Bron: ROA

\section{Opleidingen}

Ook voor opleidingstypen is de uitbreidingsvraag en de vervangingsvraag omgerekend naar het verwachte aantal baanopeningen in de periode 1989-1994. Gemiddeld is $49 \%$ van de totale toekomstige baanopeningen per opleidingstype het gevolg van werkgelegenheidstoename en $51 \%$ het gevolg van de toekomstige vervangingsvraag". In tabel 2.11. en 2.12. worden de tien beroepsklassen met respectievelijk de meeste en de minste verwachte baanopeningen per opleidingstype gepresenteerd.

Evenals voor de beroepsklassen geldt voor de opleidingstypen dat het hoge aantal (relatieve)

11. Deze verdeling verschilt met die bij de beroepsklassen vanwege de verschillende definities van de vervangingsvraag per beroep en opleiding. 
baanopeningen voornamelijk tot stand komt door een hoge uitbreidingsvraag. Alleen voor het opleidingstype 'HBO Theologisch' geldt dat het grootste deel van de verwachte totale vraag naar nieuwkomers voortvloeit uit de vervangingsvraag. Het relatief gezien grootste aantal baanopeningen wordt verwacht voor het opleidingstype 'HBO Technische Bedrijfskunde' (55\%). Verder valt op dat met name voor enkele opleidingstypen op HBO-niveau het relatieve aantal baanopeningen hoog is.

Tabel 2.11. Opleidingstypen met de meeste baanopeningen 1989-1994 (absolute aantallen en als percentage van het aantal werkenden in 1989)

Opleidingstype

baanopeningen
aantal

\begin{abstract}
Absoluut
MBO Economisch-Administratief

MBO Verzorgend

MBO Technisch

MAVO en onderbouw HAVO/NWO

LBO Technisch

LBO Verzorgend

Bovenbouw HAVO/VWO

Basisonderwijs

HBO Economisch-Administratief

MBO Verpleging \& Ziekenverzorging

\section{Relatief}

HBO Technische Bedrijfskunde

MBO Verzorgend

WO Wis-/Natuurkunde

LBO Beveiliging \& Bewaking

wO Technisch

MBO Sociaal-Cultureel

HBO Theologisch

HBO Technisch Laboratorium

LBO Verzorgend

HBO Technisch
\end{abstract}

173.500 25

111.700

90.900

46

87.400

85.700

17

84.900

16

51.400

31

50.000

42.200

41.800

5.000

111.700

16.900

2.200

21.600

13.900

33

1.600

8.400

84.900

Bron: ROA

De opleidingstypen waarvoor een werkgelegenheidsdaling wordt verwacht (zie tabel 2.4.), hebben in het algemeen een ongunstige (totale) vraagpositie op de arbeidsmarkt. Deze opleidingstypen komen, met uitzondering van 'LBO Technisch', allemaal voor in de lijst van opleidingstypen met een relatief laag verwacht aantal baanopeningen. De totale vraag is relatief gezien het laagst voor het 'Basisonderwijs'. Het aantal baanopeningen voor dit opleidingstype bedraagt naar verwachting slechts $7 \%$ van het aantal werkenden in 1989, geheel voortvloeiend uit een vervanging van uitstromende arbeidskrachten. 
Tabel 2.12. Opleidingstypen met de minste baanopeningen 1989-1994 labsolute aantallen en als percentage van het aantal werkenden in 1989)

Opleidingstype

baanopeningen

aantal

\begin{tabular}{lrr} 
Absoluut & & \\
WO Kunst & 700 & 9 \\
WO Agrarisch & 1.200 & 13 \\
MBO Technisch Laboratorium & 1.300 & 9 \\
WO Theologisch & 1.500 & 16 \\
HBO Tolk \& Vertaler & 1.500 & 25 \\
HBO Politie \& Defensie & 1.600 & 14 \\
HBO Theologisch & 1.600 & 33 \\
WO Onderwijs & 2.000 & 9 \\
HBO Bestuurlijk & 2.200 & 10 \\
LBO Beveiliging \& Bewaking & 2.200 & 36 \\
Relatief & & \\
& & \\
Basisonderwijs & & 7 \\
MBO Horeca \& Kappers & & \\
MBO Agrarisch & 50.000 & 9 \\
WO Onderwijs & 4.300 & 9 \\
WO Kunst & 10.800 & 9 \\
MBO Technisch Laboratorium & 2.000 & 700 \\
HBO Onderwijs & 1.300 & 10 \\
HBO Bestuurlijk & 26.500 & 10 \\
LBO Agrarisch & 2.200 & 11 \\
LBO Economisch-Administratief & 11.800 & 12 \\
\hline
\end{tabular}

Bron: ROA

\subsection{Instroom van schoolverlaters}

De in de vorige paragrafen beschreven ontwikkelingen spelen zich allemaal af aan de vraagkant van de arbeidsmarkt. Om inzicht te krijgen in de toekomstige arbeidsmarktpositie per opleidingstype, moeten ook de ontwikkelingen aan de aanbodzijde van de arbeidsmarkt worden belicht. Tabel 2.13. geeft een overzicht van de opleidingstypen waarvoor in de prognoseperiode 19891994 een hoge instroom van schoolverlaters op de arbeidsmarkt wordt verwacht.

Met name het basisonderwijs ${ }^{12}$, het algemeen vormend onderwijs en de opleidingstypen op MBO-niveau worden geconfronteerd met een in absolute termen hoge instroom van schoolverlaters op de arbeidsmarkt. Dit betreft echter vooral opleidingstypen die door een groot deel van de reeds werkzame bevolking zijn gevolgd. Bij de instroom van schoolverlaters van het MBO moet worden bedacht dat deze niet alleen is toe te schrijven aan het reguliere voltijdonderwijs, maar in belangrijke mate ook aan het deeltijd Kort Middelbaar

12. Dit betreft de drop-outs van het voortgezet onderwijs. 
Beroepsonderwijs' (KMBO) en het leerlingwezen (bijvoorbeeld 'MBO Technisch' en 'MBO Verzorgend'). De grote absolute instroom op de arbeidsmarkt van het opleidingstype 'MBO Verpleging \& Ziekenverzorging' komt vooral op het conto van het in-service onderwijs.

Tabel 2.13. Opleidingstypen met de hoogste instroom van schoolverlaters 1989-1994 (absolute aantaillen en als percentage van het aantal werkenden in 1989)

Opleidingstype

instroom schoolverlaters

aantal

\section{Absoluut}

MBO Technisch

MBO Economisch-Administratief

Bovenbouw HAVO/NWO

Basisonderwijs

LBO Technisch

MBO Verzorgend

MBO Verpleging \& Ziekenverzorging

MAVO en onderbouw HAVONWO

HBO Onderwijs

HBO Verpleging \& Paramedisch

\section{Relatief}

MBO Sociaal-Cultureel

WO Rechten \& Bestuurskunde

WO Econom(etr)ie \& Bedrijfskunde

Wo Humaniora

HBO Agrarisch

WO Kunst

WO Agrarisch

HBO Technische Bedrijfskunde

HBO Verpleging \& Paramedisch

WO Sociaal-Cultureel
155.200

135.300

96.100

94.600

70.200

65.400

50.100

40.700

38.200

31.700

23.800

24.700

26.100

18.200

7.500

3.400

4.200

4.000

31.700

28.400
23

19

28

14

13

27

27

8

14

41

Bron: ROA

Relatief gezien is met name bij opleidingstypen in het HBO en het WO sprake van een hoge instroom op de arbeidsmarkt. Het hoogste instroompercentage, met maar liefst $57 \%$ van het aantal werkenden in 1989, wordt echter verwacht voor het opleidingstype 'MBO SociaalCultureel'. Ook voor de WO-opleidingen 'Rechten \& Bestuurskunde', 'Econom(etr)ie \& Bedrijfskunde' en 'Humanoria' bedraagt de instroom meer dan $50 \%$ van de werkgelegenheid in 1989.

In tabel 2.14. worden de opleidingstypen gepresenteerd, waarvoor de laagste instroom van schoolverlaters op de arbeidsmarkt wordt verwacht. Daarbij is de relatief lage verwachte instroom vanuit enkele opleidingstypen binnen het $L B O$ opvallend. De instroom van schoolverlaters is naar verwachting bovendien erg laag voor het opleidingstype 'MAVO en onderbouw HAVONWO'. Dit wordt veroorzaakt door de toenemende tendens dat de leerlingen 
doorleren teneinde een hogere kwalificatie te verwerven ${ }^{13}$.

Tabel 2.14. Opleidingstypen met de laagste instroom van schoolverlaters 1989-1994 labsolute aantallen en als percentage van het aantal werkenden in 1989/

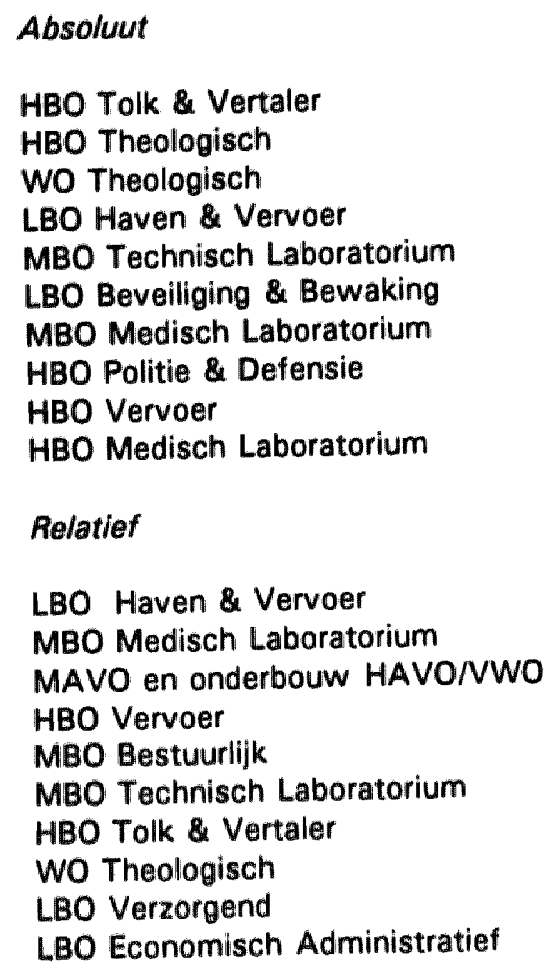

\section{Relatief}

LBO Haven \& Vervoer

MBO Medisch Labaratorium

MAVO en onderbouw HAVONWO

HBO Vervoer

MBO Bestuurlijk

MBO Technisch Laboratorium

HBO Tolk \& Vertaler

WO Theologisch

LBO Verzorgend

LBO Economisch Administratief

2.200

3.500

1.200

600

900

30.800

19.300

Bron: ROA

13. Daarbij moet worden opgemerkt dat leerlingen die na het vierde jaar van de HAVO de school verlaten op grond van de SOl-indeling van het CBS tot het opleidingstype 'Bovenbouw HAVO/NWO' worden gerekend. 


\section{DE MARKTPOSITIE VAN BEROEPEN EN OPLEIDINGEN}

\subsection{Inleiding}

De in hoofdstuk 2 beschreven stromen op de arbeidsmarkt geven een goede indicatie van de verwachte toekomstige ontwikkelingen van vraag en aanbod op de arbeidsmarkt. De relatieve marktpositie van bepaalde beroepsklassen wordt echter niet alleen door deze kwantitatieve ontwikkelingen bepaald. Het is bijvoorbeeld ook van belang na te gaan in hoeverre beroepsklassen afhankelijk zijn van de instroom van schoolverlaters. Daarnaast geeft de conjunctuurgevoeligheid van de werkgelegenheid een belangrijke indicatie van de werkzekerheid voor de werkenden in een bepaalde beroepsklasse.

De relatieve marktpositie van opleidingstypen wordt eveneens door een aantal factoren beïnvloed. Zo geeft het huidige werkloosheidspercentage een eerste beeld van de momenteel bestaande kwantitatieve aansluitingsproblemen op de arbeidsmarkt. Door een confrontatie te maken van de in hoofdstuk 2 besproken verwachte toekomstige arbeidsmarktstromen per opleidingstype wordt tevens een indicatie verkregen van de kans op absorptie- of schaarsteproblemen in de nabije toekomst. Daarnaast is het van belang of de schoolverlaters van een bepaalde opleiding voldoende uitwijkmogelijkheden hebben naar andere segmenten van de arbeidsmarkt. Tevens is de kwalitatieve aansluiting tussen onderwijs en arbeidsmarkt van belang. Wanneer veel arbeidskrachten met een bepaalde opleidingsachtergrond op een relatief laag niveau werkzaam zijn, is dat een indicatie dat de relatieve marktpositie van het desbetreffende opleidingstype zwakker is.

De verdere opzet van dit hoofdstuk is als volgt. Eerst komt in paragraaf 3.2 . de marktpositie van beroepsklassen aan de orde. Daarbij wordt achtereenvolgens ingegaan op het aandeel jongeren per beroepsklasse en de conjunctuurgevoeligheid van de werkgelegenheid. Daarna wordt in paragraaf 3.3. aandacht besteed aan de marktpositie van opleidingen. Achtereenvolgens komen daarbij de werkloosheid, de toekomstige arbeidsmarktperspectieven, de uitwijkmogelijkheden op de arbeidsmarkt en de mate van onderbenutting aan de orde.

\subsection{De marktpositie van beroepen}

Beroepsklassen die in hoge mate afhankelijk zijn van schoolverlaters of waarvan de werkgelegenheid erg conjunctuurgevoelig is, hebben een verhoogd risico op zowel kwantitatieve als kwalitatieve discrepanties op de arbeidsmarkt. De afhankelijkheid van schoolverlaters is, vanwege de te verwachten ontgroening van de beroepsbevolking, een risico-factor voor de vragers naar arbeid, terwijl de conjunctuurgevoeligheid, ofwel de mate van werkzekerheid, zowel op de vragers als op de aanbieders van arbeid betrekking heeft. Ook de in hoofdstuk 2 besproken relatief hoge vervangingsvraag (zie tabel 2.6.) kan overigens duiden op een risicofactor voor de actoren aan de vraagzijde van de arbeidsmarkt, met name indien een hoog personeelsverloop wijst op relatief onaantrekkelijke arbeidsomstandigheden. 


\section{Afhankelijkheid van schoolverlaters}

In tabel 3.1. wordt een overzicht gegeven van de tien beroepsklassen met het hoogste percentage werkenden jonger dan 30 jaar. De in deze tabel voorkomende beroepsklassen zijn derhalve in belangrijke mate afhankelijk van de instroom van jongeren (schoolverlaters) op de arbeidsmarkt. Gezien de - als gevolg van de demografische ontwikkeling (ontgroening) verwachte daling van de totale instroom van schoolverlaters op de arbeidsmarkt, brengt deze afhankelijkheid het risico met zich mee dat er knelpunten in de personeelsvoorziening van arbeidsorganisaties zullen optreden. De vermindering van de instroom van schoolverlaters op de arbeidsmarkt laat zich overigens, door de verhoogde doorstroom naar het vervolgonderwijs, vooral voelen bij het algemeen vormend onderwijs en het LBO.

Tabel 3.1. Beroepsklassen met relatief de meeste werkenden janger dan 30 jaar 1990

ROA- beroepsklasse

6211 winkel-, straat- en marktverkopers, demonstrateurs

8111 koks, kelners e.a. keuken- en serveerpersoneel

5023 dokters-, tandarts- en dierenartsassistenten

8221 kappers, schoonheidsspecialisten

5022 leerling-verpleegkundigen, zieken- en kraamverzorgenden

6112 datatypisten, computeroperators

3621 auto., motor-en bromfietsmonteurs

3621 auto*, motor- en bromfietsmonteurs

elbedienden

In tabel 3.1. komt naar voren dat de beroepsklassen met een hoog aandeel jongeren bestaan uit beroepen met een laag of middelbaar opleidingsniveau. Het blijkt dat de beroepsklasse 'winkel-, straat- en marktverkopers, demonstrateurs' het hoogste percentage werkenden jonger dan 30 jaar heeft. In deze beroepsklasse is, zoals opgemerkt in hoofdstuk 2, naar verwachting ook sprake van een relatief hoog aantal baanopeningen. Voor deze beroepen geldt in het algemeen een verhoogd risico op knelpunten in de toekomst bij het vervullen van de vraag naar nieuwkomers.

\section{Conjunctuurgevoeligheid}

Naast de afhankelijkheid van schoolverlaters kan ook de conjunctuurgevoeligheid een risicofactor zijn. Beroepsklassen met een lage conjunctuurgevoeligheid, dat wil zeggen een hoge mate van werkzekerheid, zijn relatief aantrekkelijk voor de aanbieders van arbeid. Daarmee samenhangend geldt dat voor de vragers naar arbeid een lage conjunctuurgevoeligheid van een beroepsklasse een relatief sterke concurrentiepositie op de arbeidsmarkt met zich meebrengt. 
Bovendien verhoogt een hoge conjunctuurgevoeligheid de kans dat zij met wervingsproblemen worden geconfronteerd, wanneer er bij het opleven van de conjunctuur weer veel nieuw personeel moet worden aangetrokken. Tabel 3.2. geeft een overzicht van de tien beroepsklassen met de respectievelijk hoogste en laagste conjunctuurgovoeligheid ${ }^{14}$.

Tabel 3.2. Beroepsklassen met de hoogste, respectievelijk de laagste conjunctuurgevoeligheid

ROA- beroepsklasse

code

\section{Hoog}

3211 produktiepersoneell textielindustrie

3911 metselaars, tegelzetters, straatmakers, stukadoors

3,43

3213 kleding- e.a. textiel- en bontproduktenmakers

3,41

3913 huis-, scheeps- en constructieschilders

3,40

3912 betonwerkers, dakdekkers, isoleerders, glaszetters

3,33

3914 loodgieters, sanitair-installateurs en -reparateurs

3,17

3711 samenstellers electrotechnische produkten, kwaliteitscontroleurs 2,88

3312 houtbewerkers, timmerlieden

2,86

3612 machinale metaalbewerkers

2,64

3613 lassers, constructiewerkers, edelmetaalsmeden

2,63

\section{Laag}

2012 zelfstandige agrariërs, boswachters

1,00

0131 leerkrachten basis- en speciaal onderwijs

1,02

0132 docenten voortgezet en hoger onderwijs

1,03

9221 beroepsmilitairen

6331 leden en leidinggevenden openbaar bestuur, beleidsambtenaren

1,03

3112 (zelfstandige) bakkers e.a. (industrieel) bakkerijpersonee

1,10

2011 uitvoerend agrarisch personeel, bosarbeiders

1,12

9121 politie-, brandweer-en bewakingspersoneel

1,15

6111 postdistributiepersoneel

1,18

4121 scheepsofficieren, loodsen, walinspecteurs

1,20

1,22

Bron: ROA

Opvallend is dat de tien beroepsklassen met de hoogste conjunctuurgevoeligheid allemaal betrekking hebben op lagere technische, ambachts- en industrieberoepen. De beroepsklassen met een geringe conjunctuurgevoeligheid betreffen met name enkele pedagogische beroepen en de agrarische en openbare orde- en veiligheidsberoepen.

14. De conjunctuurgevoeligheid van een beroepsklasse wordt bepaald door de sectorale werkgelegenheidsfluctuaties te relateren aan de mate waarin deze beroepsklasse aanwezig is in de verschillende bedrijfssectoren (zie voor een nadere toelichting van deze conjunctuurindicator De Grip en Heijke, 1988). 


\subsection{De marktpositie van opleidingen}

Ook de relatieve marktpositie van opleidingstypen wordt niet alleen door de kwantitatieve ontwikkeling van vraag en aanbod op de arbeidsmarkt bepaald. In deze paragraaf worden vier indicatoren besproken, die de marktpositie van opleidingen bepalen. Deze indicatoren zijn achtereenvolgens:

- huidige werkloosheid;

- toekomstige arbeidsmarktperspectieven;

- uitwijkmogelijkheden;

- onderbenutting.

\section{Huidige werkloosheid}

De huidige werkloosheid is een belangrijke indicator van de marktpositie van een bepaald opleidingstype. In het bovenste gedeelte van tabel 3.3. staan de tien opleidingstypen aangegeven met de hoogste werkloosheid ${ }^{15}$ in april 1991. In het onderste gedeelte van deze tabel zijn de opleidingstypen met een werkloosheidspercentage van minder dan $3 \%$ weergegeven.

Tabel 3.3. Opleidingstypen met de hoogste, respectievelijk de laagste werkloosheid april 1991 (bemiddelingsbestand zonder baan)

Opleidingstype

werkloosheid

$\%$

Hoog

Basisonderwijs

HBO Kunst

MAVO en onderbouw HAVO/VWO

HBO Tolk \& Vertaler

Bovenbouw HAVO/NWO

LBO Economisch-Administratief

LBO Beveiliging \& Bewaking

LBO Verzorgend

Wo Kunst

wo Humaniora

15. De werkloosheidspercentages zijn bepaald door de inschrijvingsaantallen bij de arbeidsbureaus in april 1991 (bemiddelingsbestand zonder baan) te relateren aan de som van het aantal werkenden in 1990 en de genoemde inschrijvingsaantallen in 1991 (zie ook Wieling, Dekker en De Grip, 1991). Ondanks de onnauwkeurigheid van deze data, vanwege de bestandsvervuiling en de gedeeltelijk tekortschietende codering van de opleidingsgegevens, wordt waarschijnlijk een redelijke indicatie gegeven van de relatieve ernst van de werkloosheidsproblematiek, c.q. de krapte op de arbeidsmarkt voor de verschillende opleidingstypen. 
Tabel 3.3. Opleidingstypen met de hoogste, respectievelijk de laagste werkloosheid april 1991 (bemiddelingsbestand zonder baan), vervolg

Opleidingstype

werkloosheid

$\%$

$\begin{array}{lr}\text { Laag (minder dan 3\%) } & 0 \\ \text { MBO Politie \& Defensie } & 0 \\ \text { HBO Politie \& Defensie } & 1 \\ \text { HBO Economisch-Administratief } & 1 \\ \text { MBO Bestuurlijk } & 1 \\ \text { MBO Horeca \& Kappers } & 1 \\ \text { MBO Haven \& Vervoer } & 1 \\ \text { HBO Medisch Laboratorium } & 2 \\ \text { MBO Economisch \& Administratief } & 2 \\ \text { WO Technisch } & 2 \\ \text { HBO Technisch } & 2 \\ \text { MBO Technisch } & 2 \\ \text { MBO Medisch Laboratorium } & 2 \\ \text { WO Econom(etr)ie \& Bedrijfskunde } & 2 \\ \text { MBO Agrarisch } & 2 \\ \text { HBO Theologisch } & 2 \\ \text { HBO Vervoer } & 2 \\ \text { WO Theologisch } & 2 \\ \text { WO Dier-/Genees-/Tandheelkunde } & 2 \\ \text { MBO Verpleging \& Ziekenverzorging } & 2\end{array}$

Bron: Arbeidsvoorzieningsorganisatie/ROA

In tabel 3.3. komt naar voren dat zowel opleidingstypen aan de onderkant als opleidingstypen aan de bovenkant van het onderwijssysteem worden geconfronteerd met een relatief hoog werkloosheidspercentage. Daarbij is met name de relatief slechte positie van de algemeen vormende opleidingen ('Basisonderwijs', 'MAVO' en 'HAVO/VWO') en een aantal 'zachtere' opleidingen opvallend ('HBO Kunst', 'HBO Tolk \& Vertaler', 'WO Kunst' en 'WO Humaniora'). Verder kennen enkele opleidingstypen op LBO-niveau een relatief hoge werkloosheid. Opleidingstypen met een laag werkloosheidspercentage worden vooral aangetroffen op MBO- en HBO-niveau. Ook voor een aantal academische opleidingstypen geldt een relatief laag werkloosheidspercentage.

\section{Toekomstige arbeidsmarktperspectieven}

Het werkloosheidspercentage geeft slechts een beeld van de huidige kwantitatieve aansluiting tussen vraag en aanbod op de arbeidsmarkt. Hierin kan echter (snel) verandering optreden als gevolg van ontwikkelingen aan zowel de vraagzijde als de aanbodzijde van de arbeidsmarkt. Met behulp van de door het ROA ontwikkelde indicator toekomstige arbeidsmarktsituatie wordt per opleidingstype de kans op absorptie- of schaarsteproblemen in de periode 1989-1994 bepaald. Bij deze indicator wordt een confrontatie gemaakt van de verwachte baanopeningen (uitbreidings- en vervangingsvraag) met het verwachte aanbod van nieuwkomers (instroom van 
schoolverlaters en kortdurig werklozen $)^{16}$. Bij een indicatorwaarde gelijk aan 1 geldt dat de toekomstige vraag en het toekomstige aanbod in evenwicht zijn (zie voor een nadere toelichting Dekker, De Grip, Berendsen, Wieling en Willems, 1992).

Tabel 3.4. geeft aan voor welke opleidingstypen een goed toekomstig arbeidsmarktperspectief wordt verwacht ${ }^{17}$. Uit de tabel komt naar voren dat met name opleidingstypen op MBO- en HBO-niveau een relatief gunstige positie op de toekomstige arbeidsmarkt innemen. Voor 12 van de 21 in deze tabel genoemde opleidingstypen geldt dat ook de huidige werkloosheid laag is (minder dan 3\%). Voor vier opleidingstypen waarvoor een goed toekomstig arbeidsmarktperspectief wordt verwacht is de werkloosheid in 1991 daarentegen (nog) hoog. Dit betreft de opleidingstypen 'LBO Verzorgend', 'HBO Tolk \& Vertaler', 'LBO Beveiliging \& Bewaking' en 'MAVO en onderbouW HAVO/VWO'.

Tabel 3.4. Opleidingstypen met een goed toekomstig arbeidsmarktperspectief 1989-1994

Opleidingstype

LBO Haven \& Vervoer

HBO Theologisch

0,87

WO Wis-/Natuurkunde

0,87

MBO Bestuurlijk

0,88

HBO Vervoer

0,88

MBO Verzorgend

0,88

MBO Medisch Laboratorium

0,88

HBO Technisch Laboratorium

0,89

LBO Verzorgend

0,90

MBO Politie \& Defensie

0,92

HBO Tolk \& Vertaler

0,93

MBO Haven \& Vervoer

0,93

HBO Economisch-Administratief

0,94

HBO Medisch Laboratorium

0,94

HBO Technische Bedrijfskunde

0,94

WO Theologisch

0,96

MBO Economisch \& Administratief $\quad 0,96$

wo Technisch

0,98

HBO Technisch

0,98

LBO Beveiliging \& Bewaking

MAVO en onderbouw HAVO/NWO

0,99

Bron: ROA

16. Er wordt hier uitgegaan van werklozen die korter dan 1 jaar werkloos zijn. Er wordt verondersteld dat langduriger werklozen niet concurrerend zijn met de instroom van schoolverlaters van het desbetreffende opleidingstype op de arbeidsmarkt.

17. In tegenstelling tot de andere tabellen wordt de lijst hier niet beperkt tot tien opleidingstypen, maar worden alle opleidingstypen, waarvoor een goed arbeidsmarktperspectief wordt verwacht, weergegeven. Overigens moet hierbij worden opgemerkt dat binnen de gepresenteerde opleidingstypen het beeld kan variëren. 
Met uitzondering van het opleidingstype "MBO Sociaal-Cultureel' hebben alle opleidingstypen waarvoor een (relatief) hoog aantal baanopeningen wordt verwacht (zie tabel 2.11.) een naar verwachting gunstig toekomstig arbeidsmarktperspectief. Bovenaan in de lijst met opleidingstypen met een goed toekomstig perspectief staat 'LBO Haven \& Vervoer'. Deze gunstige typering is vooral te danken aan een relatief lage verwachte instroom van schoolverlaters. De ondanks de huidige hoge werkloosheid gunstige arbeidsmarkttypering voor 'LBO Verzorgend' hangt samen met een relatief groot aantal baanopeningen en tegelijkertijd een relatief lage instroom van schoolverlaters. De verwachte omslag ten opzichte van de huidige arbeidsmarktsituatie voor de opleidingstypen 'HBO Tolk \& Vertaler' en 'MAVO en onderbouw HAVO/VWO' wordt vooral veroorzaakt door de relatief lage instroom van schoolverlaters. Voor 'LBO Beveiliging \& Bewaking' is vooral de hoge (uitbreidings)vraag verantwoordelijk voor het gunstige toekomstige arbeidsmarktperspectief.

In tabel 3.5. staan de opleidingstypen die naar verwachting een slecht toekomstig arbeidsmarktperspectief hebben ${ }^{18}$. Het valt op dat een ongunstige arbeidsmarktsituatie met name wordt verwacht voor een aantal WO-opleidingen. Deels betreft dit opleidingstypen die momenteel reeds een relatief hoge werkloosheid kennen, zoals 'WO Kunst' en 'WO Humaniora'. In totaal geldt dat voor 5 van de 14 opleidingstypen met een slecht toekomstig arbeidsmarktperspectief de huidige werkloosheid relatief hoog is. Voor twee van de in tabel 3.5. genoemde opleidingstypen is de werkloosheid in 1991 echter nog als laag getypeerd. Dit zijn de opleidingstypen 'MBO Agrarisch' en 'WO Econom(etr)ie \& Bedrijfskunde'.

Tabel 3.5. Opleidingstypen met een slecht toekomstig arbeidsmarktperspectief 1989-1994

Opleidingstype

WO Kunst

Wo Humaniora

wo Agrarisch

Basisonderwijs

MBO Agrarisch

HBO Agrarisch

HBO Verpleging \& Paramedisch

Wo Rechten \& Bestuurskunde

WO Econom(etr)ie \& Bedrijfskunde

MBO Sociaal-Cultureel

HBO Kunst

Bovenbouw HAVONWO

WO Sociaal-Cultureel

wO Onderwijs
1,45

1,36

1,35

1.33

1,32

1,32

1,26

1,25

1,22

1,22

1,20

1,18

1,18

1,16

Bron: ROA

18. Zoals gezegd kan binnen de genoemde opleidingstypen het beeld per richting afwijkend zijn. 
De opleidingstypen met een slecht toekomstig arbeidsmarktperspectief kampen vooral met een hoge verwachte instroom van schoolverlaters in de nabije toekomst. Maar liefst negen opleidingstypen met een naar verwachting relatief hoge instroom van schoolverlaters (zie tabel 2.13.) worden getypeerd met een slecht arbeidsmarktperspectief. Voor vier opleidingstypen is een relatief laag aantal baanopeningen (mede) verantwoordelijk voor de slechte arbeidsmarkttypering.

Zoals reeds is aangegeven, is in tabel 3.5. de positie van twee opleidingstypen het meest opvallend, te weten 'MBO Agrarisch' en 'WO Econom(etr)ie \& Bedrijfskunde'. Het 'MBO Agrarisch' heeft vooral te kampen met een relatief laag aantal baanopeningen. Het opleidingstype 'WO Econom(etr)ie \& Bedrijfskunde' heeft daarentegen te maken met een naar verwachting relatief erg hoge instroom van afgestudeerden op de arbeidsmarkt. Daarbij moet overigens worden opgemerkt dat de verwachte arbeidsmarktperspectieven van het opleidingstype 'HBO Economisch-Administratief' goed zijn, waardoor WO-afgestudeerden mogelijk op HBO-functies terecht kunnen komen.

\section{Uitwijkmogelijkheden}

Voor opleidingen met een slecht toekomstig arbeidsmarktperspectief betekent dit niet dat automatisch absorptieproblemen op de arbeidsmarkt zullen ontstaan. Net zo min betekent een goed toekomstig arbeidsmarktperspectief automatisch dat alle schoolverlaters met de desbetreffende opleidingsachtergrond passend werk zullen vinden. Zo kunnen schooiverlaters van opleidingen met een in kwantitatieve zin slechte arbeidsmarktsituatie uitwijken naar beroepsdomeinen van andere opleidingen waar de perspectieven gunstiger lijken te zijn. Op deze manier kunnen de schoolverlaters van de laatstgenoemde opleidingen worden geconfronteerd met verdringings- en substitutieprocessen, waardoor een in eerste instantie goed arbeidsmarktperspectief uiteindelijk toch minder rooskleurig blijkt te zijn.

In tabel 3.6. wordt een overzicht gegeven van de uitwijkmogelijkheden per opleidingstype. De uitwijkmogelijkheden worden daarbij getypeerd met een spreidingsmaatstaf, welke aangeeft hoe groot de spreiding van de werkenden met een bepaalde opleidingsachtergrond over de verschillende beroepsgroepen is. Als spreidingsindex is gekozen voor de Gini-Hirschman coüfficiënt, een maatstaf die de waarde 0 aanneemt als alle arbeidskrachten met een bepaalde opleidingsachtergrond geconcentreerd zijn in één beroep en de waarde 1 als de werkenden gelijkmatig zijn verdeeld over alle beroepen (zie De Grip en Heijke, 1988) ${ }^{19}$. Daarbij zijn de uitwijkmogelijkheden naar beroepsgroepen met een in vergelijking tot de gevolgde opleiding te laag functieniveau (zie Huijgen, 1989) buiten beschouwing gelaten, omdat er dan immers geen sprake is van 'echte' (marktpositieverbeterende) alternatieven (zie ook De Grip, Van der Velden en Wieling, 1991). Verder is het van belang om op te merken dat de gehanteerde maatstaf op

19. Aangezien de Gini-Hirschman coëfficiënt gevoelig is voor het gekozen aggregatieniveau, is het van belang op te merken dat de spreiding van de opleidingstypen over de (CBS 3-digit) beroepsgroepen is bepaald. 
de gerealiseerde en niet op de potentiêle vitwijkmogelijkheden betrekking heeft.

De algemeen vormende opleidingen ("Basisonderwijs', 'MAVO' en 'HAVO/VWO') hebben relatief veel uitwijkmogelijkheden. Ook de opleidingstypen in technische richting worden op alle opleidingsniveaus gekenmerkt door relatief veel uitwijkmogelijkheden. Daarbij moet worden opgemerkt dat deze technische opleidingstypen een breed scala aan heterogene opleidingsrichtingen omvatten, waardoor de uitwijkmogelijkheden wellicht te rooskleurig zijn ingeschat. Opleidingstypen voor (semi)-geprofessionaliseerde vakdeelmarkten, zoals in de gezondheidszorg en bij religieuze instellingen, hebben relatief weinig uitwijkmogelijkheden. Hetzelfde geldt voor de agrarische opleidingen op lager en middelbaar niveau.

Tabel 3.6. Opleidingstypen met de meeste, respectievelijk de minste uitwijkmogelijkheden op aansluitend of hoger functieniveau 1990

Veel

$\begin{array}{lc}\text { Basisonderwijs } & 0,98 \\ \text { MBO Technisch } & 0,97 \\ \text { LBO Technisch } & 0,97 \\ \text { HBO Technisch } & 0,96 \\ \text { LBO Haven \& Vervoer } & 0,96 \\ \text { WO Technisch } & 0,96 \\ \text { Bovenbouw HAVONWO } & 0,96 \\ \text { MBO Economisch \& Administratief } & 0,96 \\ \text { HBO Vervoer } & 0,95 \\ \text { MAVO en onderbouw HAVO/VwO } & 0,95\end{array}$

Weinig

$\begin{array}{ll}\text { Wo Dier-/Genees- } / \text { Tandheelkunde } & 0,49\end{array}$

$\begin{array}{ll}\text { HBO Theologisch } & 0,58\end{array}$

$\begin{array}{ll}\text { MBO Medisch Laboratorium } & 0,66\end{array}$

$\begin{array}{ll}\text { WO Theologisch } & 0,67\end{array}$

$\begin{array}{ll}\text { MBO Technisch Laboratorium } & 0,68\end{array}$

$\begin{array}{ll}\text { Wo Humaniora } & 0,70\end{array}$

MBO Verpleging \& Ziekenverzorging $\quad 0,72$

$\begin{array}{ll}\text { HBO Medisch Laboratorium } & 0,72\end{array}$

$\begin{array}{ll}\text { MBO Agrarisch } & 0,74\end{array}$

$\begin{array}{lr}\text { LBO Agrarisch } & 0,76\end{array}$

Bron: ROA

\section{Onderbenutting}

Hierboven is reeds aangegeven dat arbeidskrachten met een bepaalde opleidingsachtergrond kunnen uitwijken naar andere beroepsdomeinen. Daarbij is alleen gekeken naar de uitwijkmogelijkheden op aansluitend en hoger functieniveau. Uitwijkmogelijkheden naar andere 
beroepsniveaus houden immers een onderbenutting ${ }^{20}$ van de bij de arbeidskrachten aanwezige kwalificaties in. Terwijl uitwijkmogelijkheden naar beroepen op een aansluitend of hoger functieniveau duiden op een relatief gunstige marktpositie, wijst een hoge mate van onderbenutting daarentegen op een ongunstige marktpositie. In tabel 3.7. worden respectievelijk de tien opleidingstypen met het hoogste en het laagste percentage onderbenutting in 1990 gepresenteerd ${ }^{21}$.

Tabel 3.7. Opleidingstypen met het hoogste, respectievelijk het laagste percentage onderbenutting 1990

Veel

LBO Haven \& Vervoer 78

HBO Politie \& Defensie

LBO Beveiliging \& Bewaking

LBO Verzorgend

MBO Verzorgend 59

HBO Economisch-Administratief

MBO Politie \& Defensie

Bovenbouw HAVO/VWO

MAVO en onderbouw HAVO/VWO

MBO Haven \& Vervoer

\section{Weinig}

Basisonderwijs

WO Dier-/Genees-/Tandheelkunde

HBO Technisch Laboratorium

HBO Verpleging \& Paramedisch

HBO Technisch

WO Agrarisch

HBO Kunst

Wo Onderwijs

MBO Verpleging \& Ziekenverzorging

HBO Onderwijs

0

7

10

10

13

13

13

14

14

14

Bron: ROA

In de lijst met opleidingstypen met relatief veel onderbenutting worden zowel enkele LBO-, $\mathrm{MBO}$ - als HBO- opleidingstypen aangetroffen. Het hoogste percentage arbeidskrachten dat wordt onderbenut geldt voor het 'LBO Haven \& Vervoer'. Maar liefst $78 \%$ van de werkenden is

20. Onderbenutting treedt op als het functieniveau van arbeidskrachten te laag is ten opzichte van het opleidingsniveau. Zie Huijgen (1989).

21. Overigens is enige voorzichtigheid bij de interpretatie geboden, aangezien de onderbenuttingsmaatstaf van Huijgen (1989) eigenlijk te grofmazig is en daardoor slechts 'grove indicaties' van de mate van onderbenutting kan geven (zie ook Ministerie van Sociale Zaken en Werkgelegenheid, 1989). 
werkzaam op een te laag niveau. Opvallend is verder dat de algemeen voortgezette opleidingen ('MAVO' en 'HAVO/NWO') met een relatief hoog percentage onderbenutting worden geconfronteerd. Wellicht wijst dit er op dat het uitsluitend volgen van een algemene opleiding op de huidige arbeidsmarkt niet langer voldoende is voor de uitoefening van een functie op een niveau dat in overeenstemming is met deze opleiding.

Vanzelfsprekend heeft het 'Basisonderwijs' het laagste percentage onderbenutting, omdat onderbenutting van ongeschoolde arbeid per definitie is uitgesloten. Verder treft men in de lijst met opleidingstypen met relatief weinig onderbenutting vooral WO- en HBO-opleidingen aan. Het gaat daarbij vooral om opleidingen die voorbereiden op een geprofessionaliseerde vakdeelmarkt, binnen de gezondheidszorg of het onderwijs. Er bestaat in deze deelmarkten een sterke regulering met de betrekking tot de diploma-vereisten voor de beroepsintrede: concurrentie vanuit andere opleidingstypen is bij wet verboden. De (gerealiseerde) uitwijkmogelijkheden zijn voor deze opleidingstypen echter ook laag (zie tabel 3.6.) Dit geeft deze opleidingen een specifieke positie op de arbeidsmarkt, waarbij de marktpositie vooral wordt bepaald door de kwantitatieve ontwikkelingen op het arbeidsmarktsegment, waarvoor men is opgeleid.

\section{Resume}

In deze paragraaf is een aantal indicatoren besproken die kunnen duiden op een relatief goede dan wel slechte marktpositie. In eerste instantie geeft de huidige werkloosheid een beeld van de actuele schaarsteverhoudingen op de arbeidsmarkt. Het toekomstige arbeidsmarktperspectief geeft een belangrijke indicatie van de marktpositie op de middellange termijn. De uitwijkmogelijkheden op de arbeidsmarkt naar beroepsgroepen op een aansluitend of hoger functieniveau vormen hierop een belangrijke aanvulling voor wat betreft de flexibiliteit van afgestudeerden bij minder goede vooruitzichten. De mate van onderbenutting indiceert enerzijds of schoolverlaters bij een ruime arbeidsmarkt ook (kunnen) uitwijken naar functies op een lager niveau, waardoor men niet werkloos hoeft te worden. Doordat hier is gekeken naar de mate waarin er momenteel sprake is van onderbenutting, wijst een hoge onderbenutting er anderzijds echter ook op dat personen met de desbetreffende opleidingsachtergrond nu al problemen hebben om werk te vinden op het bij deze opleiding aansluitende functieniveau.

Voor de meeste opleidingstypen is het beeld dat kan worden geschetst van de marktpositie van de afgestudeerden in meer of mindere mate genuanceerd. Op basis van bovenstaande gegevens zijn echter wel enkele clusters te onderscheiden van opleidingen met een vergelijkbare arbeidsmarktpositie. Van een zeer gunstige marktpositie is sprake bij een aantal opleidingstypen met relatief veel uitwijkmogelijkheden op de arbeidsmarkt. Het meest opvallend daarbij is het opleidingstype 'HBO Technisch', waarvoor op dit moment sprake is van een lage werkloosheid, het toekomstige arbeidsmarktperspectief goed is te noemen, er bovendien veel uitwijkmogelijkheden zijn en slechts weinig arbeidskrachten beneden hun niveau actief zijn. Voor de opleidingstypen 'MBO Economisch \& Administratief', 'HBO Vervoer' en 'WO Technisch' kan eveneens van een goede marktpositie worden gesproken. Terwijl de huidige werkloosheid voor 
deze opleidingstypen reeds laag is, geldt dat ook voor de nabije toekomst een goed arbeidsmarktperspectief wordt verwacht, waarbij bovendien de vitwijkmogelijkheden naar andere beroepsdomeinen groot zijn.

Een bijzonder slechte marktpositie doet zich voor bij de opleidingstypen 'Bovenbouw HAVONWO' en 'WO Humaniora'. Voor beide opleidingstypen geldt dat er momenteel sprake is van een relatief hoge werkloosheid, terwijl ook de toekomstige arbeidsmarktsituatie als slecht wordt getypeerd. Bovendien geldt voor de 'Bovenbouw HAVONWO' dat veel arbeidskrachten op een relatief laag functieniveau werkzaam zijn en voor 'WO Humaniora' dat er slechts geringe uitwijkmogelijkheden bestaan. Tenslotte kan ook voor het 'Basisonderwijs' de marktpositie als slecht worden getypeerd. De uitwijkmogelijkheden voor dit opleidingstype zijn weliswaar groot, maar dat wordt veroorzaakt doordat voor de meeste functies, waarin degenen met alleen een opleiding 'Basisonderwijs' werkzaam zijn, geen specifieke kwalificaties worden gevraagd. Het feit dat voor dit opleidingstype geen onderbenutting optreedt, is louter een bodemeffect. De slechte marktpositio van dit opleidingstype uit zich vooral in een erg hoge werkloosheid en een slecht toekomstig arbeidsmarktperspectief. 


\section{HET TECHNISCH ONDERWIJS NADER BELICHT}

\subsection{Inleiding}

Het technisch onderwijs staat al enige tijd sterk in de belangstelling. In de door het Ministerie van Economische Zaken (1990) opgestelde sterkte-zwakte analyse van de Nederlandse economie wordt gewezen op het belang van het technisch onderwijs voor de technologische en daarmee ook voor de economische ontwikkeling van ons land. Tegen deze achtergrond wordt in dit hoofdstuk een beschrijving gegeven van de positie van technische beroepen en technische opleidingen op de arbeidsmarkt ${ }^{22}$.

De opzet van dit hoofdstuk is als volgt. Alvorens in te gaan op de technische beroepen en technische opleidingen komt in paragraaf 4.2. eerst de ontwikkeling van de kwalificatiestructuur van het arbeidsaanbod van nieuwkomers op de arbeidsmarkt aan de orde, vanwege het belang van de ontwikkeling van het aantal hoger opgeleiden voor het creëren van een gunstige voedingsbodem voor de technologische ontwikkeling. Daarna wordt in deze paragraaf meer specifiek ingegaan op de ontwikkeling van de kwalificatiestructuur van de nieuwkomers op de arbeidsmarkt met een technische opleidingsachtergrond. In paragraaf 4.3. komt vervolgens de marktpositie van technische beroepen aan de orde. Paragraaf 4.4. behandelt tenslotte de marktpositie van technische opleidingen.

\subsection{Ontwikkeling van de kwalificatiestructuur van het arbeidsaanbod}

De kwalificatiestructuur van de beroepsbevolking is een belangrijke determinant van de technologische ontwikkeling. Enerzijds bepaalt de scholingsgraad van de beroepsbevolking in sterke mate het innovatievermogen van de samenleving, anderzijds is dit een belangrijke determinant voor de snelheid waarmee technologische vernieuwingen op grote schaal kunnen worden doorgevoerd. Voor de ontwikkeling van de kwalificatiestructuur van de beroepsbevolking is het van bijzonder belang op welke wijze het opleidingsniveau van de schoolverlaters zich ontwikkelt. Figuur 4.1. geeft aan hoe het aandeel van de hoger opgeleiden in de gediplomeerde uitstroom uit het initiële dagonderwijs zich in de periode 1978/79-1988/89 heeft ontwikkeld en wat de prognoses zijn van deze uitstroom voor de periode 1988/89-1993/94. Daarbij wordt enerzijds afzonderlijk gekeken naar het wetenschappelijk onderwijs (WOI en het hoger beroepsonderwijs ( $\mathrm{HBO}$ ) en anderzijds naar het totaal van deze twee opleidingsniveaus, het hoger onderwijs $\left(\mathrm{HO}^{23}\right.$.

22. Zie voor een specifieke prognosestudie van de arbeidsmarkt voor research and development-personeel Berendsen, De Grip en Willems (1991).

23. De historische cijfers zijn daarbij afkomstig van de Onderwijsmatrices 1979-1989 van het CBS en de prognosecijfers van het Ministerie van Onderwijs en Wetenschappen (1991). Als gevolg van deze overgang treedt in figuur 4.1. een kleine trendbreuk op. 
Figuur 4.1. Ontwikkeling percentage hoger opgeleiden in de gediplomeerde uitstroom uit het initielle dagonderwijs 1978/79-1993/94

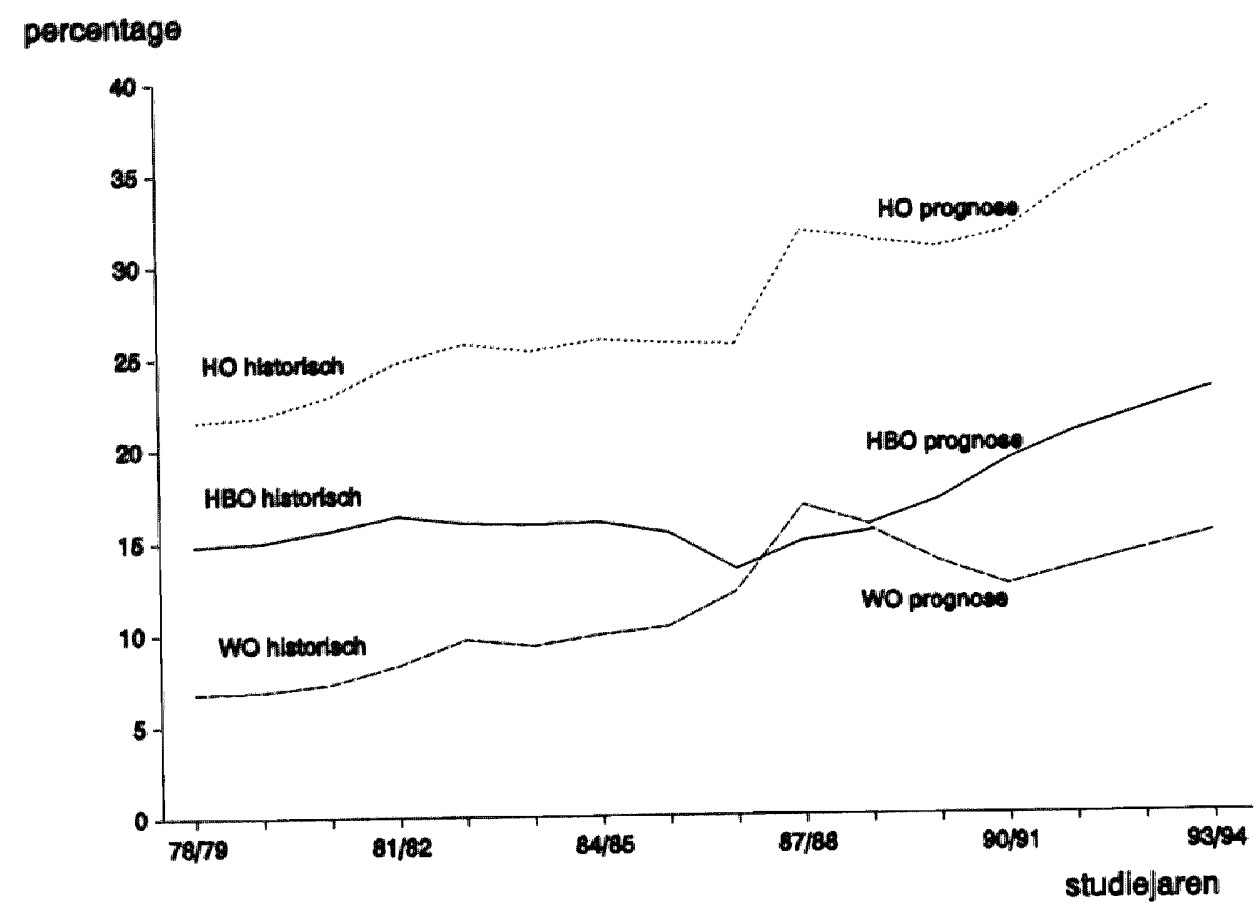

Bron: CBS/Ministerie van Onderwijs en Wetenschappen/ROA

In de periode 1978/79-1988/89 neemt het aandeel van de hoger opgeleiden in de totale uitstroom van gediplomeerden met ongeveer 10 procentpunten toe van ruim $21 \%$ tot circa $31 \%$. Deze groei komt voornamelijk voor rekening van de universitair opgeleiden. Deze stijging is gedeeltelijk veroorzaakt door de 'dubbele uitstroom' als gevolg van de overgang naar de twee-fasen-structuur in het wetenschappelijk onderwijs. Voor de periode 1988/89-1993/1994 wordt een verdere toename tot ongeveer $38 \%$ verwacht. Deze groei komt echter geheel voor rekening van de ontwikkeling van de uitstroom van het $\mathrm{HBO}$.

Voor het innovatiepotentieel van de beroepsbevolking is niet alleen de hoogte van het opleidingsniveau, maar vanzelfsprekend ook de richting van de gevolgde opleiding van belang. Daarbij is vooral de ontwikkeling van het aantal technisch ${ }^{24}$ opgeleiden belangrijk. In figuur 4.2. staat aangegeven hoe het aandeel van technisch opgeleiden in de gediplomeerde uitstroom uit het initieel dagonderwijs zich in het verleden heeft ontwikkeld en wat de verwachtingen op de middellange termijn zijn. Er wordt daarbij onderscheid gemaakt tussen het MBO en het hoger onderwijs ( $\mathrm{HO}$ ).

24. Daarbij is noodzakelijkerwijs een globale opleidingscategorie 'technisch' gehanteerd, die niet geheel overeenkomt met de ROA-opleidingsindeling. 
Figuur 4.2. Ontwikkeling percentage technisch opgeleiden binnen de gediplomeerde uitstroom uit het initiêle onderwijs per opleidingsniveau 1978/79-1993/94

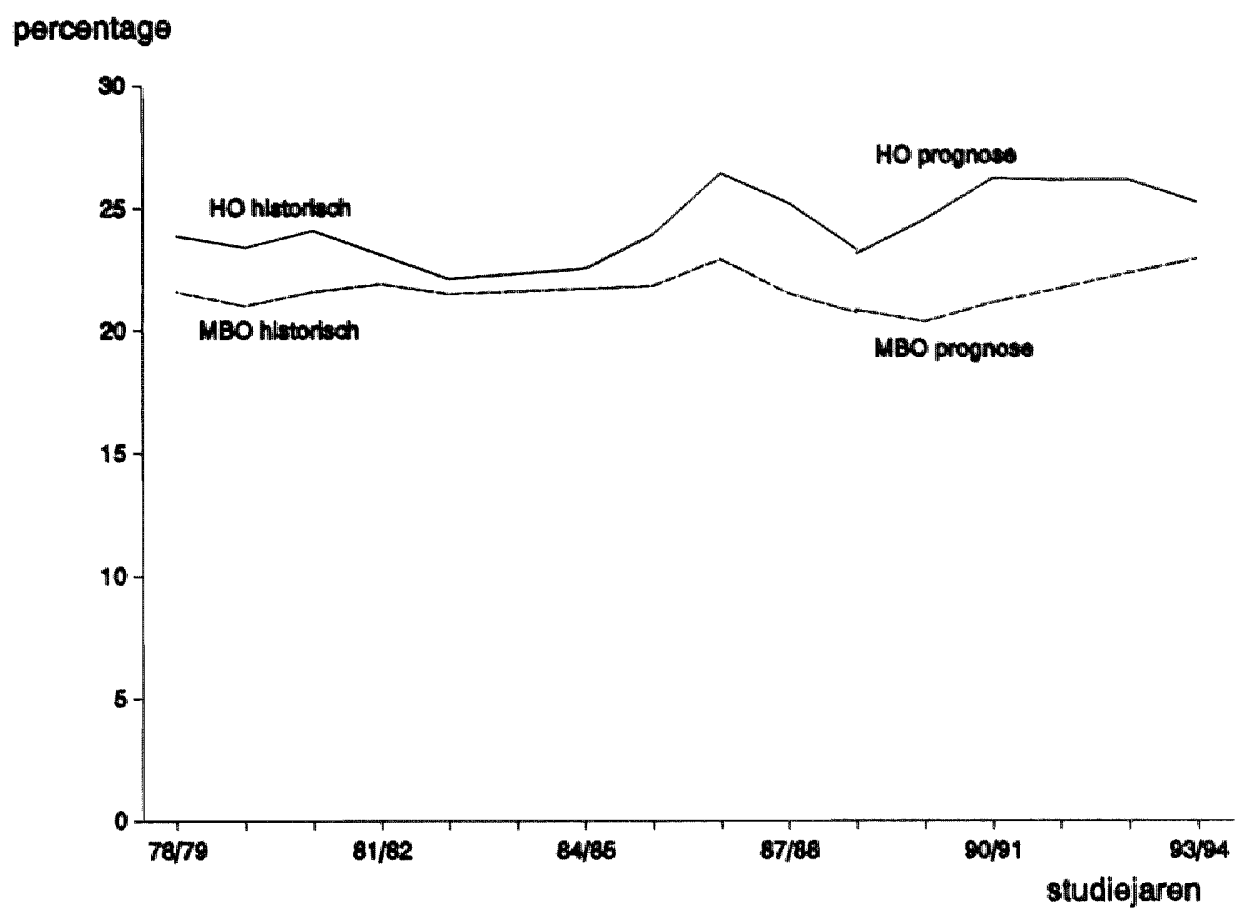

Bron: CBS/Ministerie van Onderwijs en Wetenschappen/ROA

Binnen het MBO is het aandeel technisch opgeleiden zeer constant: voor zowel de historische als de prognoseperiode schommelt dit rond de $22 \%$. Ook voor het hoger onderwijs is het aandeel van technisch opgeleiden met $24 \%$ tamelijk constant, met een lichte stijging naar $25 \%$ in de prognoseperiode. Ondanks dit constante aandeel van technisch opgeleiden binnen de verschillende opleidingsniveaus, neemt het aandeel van technisch opgeleiden in de totale gediplomeerde uitstroom toe, als gevolg van de groei van het MBO en het hoger onderwijs.

\subsection{De marktpositie van technische beroepen}

In deze paragraaf worden enkele indicatoren besproken die de marktpositie van technische beroepen bepalen. Daarbij wordt achtereenvolgens gekeken naar de verwachte baanopeningen, de afhankelijkheid van schoolverlaters en de conjunctuurgevoeligheid van de werkgelegenheid (zie ook hoofdstuk 2 en 3). In totaal worden 40 ROA-beroepsklassen tot de 'technische beroepen' gerekend, te weten 35 'technische, ambachts- en industrieberoepen' en 5 
'transportberoepen'25. Vanwege het grote aantal technische beroepen is in de tabellen een ordening naar niveau aangebracht.

\section{Baanopeningen}

In tabel 4.1. wordt het verwachte aantal baanopeningen in de prognoseperiode 1989-1994 voor de verschillende technische beroepen gepresenteerd. Daarbij is tevens met een typering aangegeven hoe het verwachte aantal baanopeningen voor de technische beroepen in relatieve zin verschilt van het algehele beeld ${ }^{2 \theta}$. Met behulp van een '"' zijn de beroepsklassen aangegeven waarbij de baanopeningen voornamelijk als gevolg van de verwachte uitbreidingsvraag tot stand komen.

De technische beroepen waarvoor een zowel absoluut als relatief gezien groot aantal baanopeningen worden verwacht, betreffen met name beroepsklassen op middelbaar of hoger niveau, zoals de 'directeuren, bedrijfsleiders, leidinggevenden industrie' en de 'bètaonderzoekers, technische vakspecialisten'. Ook de beroepsklassen 'technische en medische vertegenwoordigers', 'technische tekenaars' en 'technische analisten, amanuenses' kennen relatief gezien een naar verwachting groot aantal baanopeningen. De totale vraag naar nieuwkomers bedraagt voor deze beroepsklassen meer dan $40 \%$ van het aantal werkenden in 1989, voornamelijk als gevolg van een sterk toenemende werkgelegenheid. Voor de technische beroepen op lager niveau geldt, met uitzondering van de beroepsklassen 'conducteurs, chauffeurs e.a. transportmiddelenbestuurders', dat het verwachte aantal toekomstige baanopeningen relatief (erg) laag of gemiddeld is. Voor deze beroepsklassen is de vraag naar nieuwkomers in belangrijke mate afhankelijk van de vervangingsbehoefte.

\section{Afhankelijkheid van schoolverlaters}

In tabel 4.2. staat voor de technische beroepen aangegeven hoe groot het percentage werkenden jonger dan 30 jaar is. Dit percentage geeft een indicatie van de mate waarin werkgevers bij het aantrekken van nieuw personeel zijn aangewezen op schoolverlaters. Zoals in hoofdstuk 3 werd opgemerkt duidt een grote afhankelijkheid van schoolverlaters er op dat de vragers naar arbeid gevoelig zijn voor de verwachte ontgroening van het aanbod op de arbeidsmarkt.

Van de 40 onderscheiden technische beroepen blijken er 21 een meer dan gemiddeld aandeel van jongeren te hebben. Bij 12 - vooral hogere (leidinggevende) - beroepsklassen is het aandeel

25. In de ROA-beroepenclassificatie zijn dit respectievelijk de beroepsklassen met de eerste digit gelijk aan 3 en de beroepsklassen met als eerste digit 4 .

26. Zie voor de gehanteerde methodiek bij de typering van kwantitatieve arbeidsmarktinformatie Wieling, De Grip en Willems (1990). 
Tabel 4.1. Baanopeningen 'technische beroepen' 1989-1994 (absolute aantallen en als percentage van het aantal werkenden in 1989/

ROA- beroepsklasse

code

baanopeningen

aantal $\%$ typering

\section{Lagere beroepen}

3011 heftruck- en hefvorkchauffeurs

3012 machinisten bouw en industrie

3111 voedingsmiddelenbereiders

3112 (zelfstandige) bakkers e.a. (industrieel) bakkerijpersoneel

3211 produktiepersoneel textielindustrie

3212 stoffeerders, schoen- e.a. lederwarenmakers

3213 kleding- e.a. textiell- en bontproduktenmakers

3311 houtzagers, hout(waren)-, papier- en kartonmakers

3312 houtbewerkers, timmerlieden

3411 drukkers, boekbinders, fotolaboranten

3511 produktiepersoneel chemische industrie

3611 delfstoffen(be)werkers, metaalvervaardigers

3612 machinale metaalbewerkers

3613 lassers, constructiewerkers, edelmetaalsmeden

3614 machinebank- en plaatwerkers, gereedschaps- en modelmakers

3615 onderhoudsmonteurs, fietsen- en instrumentmakers

3711 samenstellers electrotechnische produkten, kwaliteitscontroleurs

3811 produktiepersoneel bouwmaterialen-, glas- en aardewerkindustrie

3911 metselaars, tegelzetters, straatmakers, stukadoors

3912 betonwerkers, dakdekkers, isoleerders, glaszetters

3913 huis-, scheeps- en constructieschilders

3914 loodgieters, sanitair-installateurs en -reparateurs

3915 overige bouwvaklieden, (spoor)weg- en reinigingswerkers

4011 laders, lossers, vul- en inpak(machine)bedienden

4112 matrozen e.a. scheepsdek- en machinekamerpersoneel

4211 conducteurs, chauffeurs e.a. transportmiddelenbestuurders

\section{Middelbare beroepen}

3021 directeuren, bedrijfsleiders leidinggevenden industrie

3022 technische en medische vertegenwoordigers

3023 technische tekenaars

3024 technische analisten, amanuenses

3621 auto-, motor- en bromfietsmonteurs

3622 middelbare (scheeps/werktuigkundigen e.a. metaalkundigen

3721 electriciens, electro- en telecom(onderhouds)monteurs

3921 bouwkundige technici, opzichters, werkvoorbereiders

4121 scheepsofficieren, loodsen, walinspecteurs

4321 vliegers, boordwerktuigkundigen, transportdienstleiders

$\begin{array}{rrl}3.000 & 14 & \text { gemiddeld* } \\ 1.600 & 5 & \text { laag } \\ 6.300 & 14 & \text { gemiddeld } \\ 1.800 & 7 & \text { laag } \\ 1.700 & 15 & \text { gemiddeld } \\ 3.000 & 14 & \text { gemiddeld } \\ 6.300 & 23 & \text { gemiddeld } \\ 1.400 & 13 & \text { laag } \\ 8.300 & 7 & \text { laag } \\ 8.800 & 15 & \text { gemiddeld } \\ 4.900 & 16 & \text { gemiddeld } \\ 1.800 & 14 & \text { gemiddeld } \\ 5.200 & 13 & \text { laag } \\ 5.800 & 9 & \text { laag } \\ 7.100 & 10 & \text { laag } \\ 9.000 & 12 & \text { laag } \\ 5.900 & 21 & \text { gemiddeld } \\ 3.600 & 12 & \text { laag } \\ 3.500 & 7 & \text { laag } \\ 3.300 & 15 & \text { gemiddeld } \\ 1.000 & 3 & \text { erg laag } \\ 2.300 & 5 & \text { laag } \\ 3.700 & 5 & \text { laag } \\ 16.600 & 14 & \text { gemiddeld } \\ 1.300 & 22 & \text { gemiddeld } \\ 52.200 & 29 & \text { hoog } \\ & & \end{array}$

134.600

3.200

40

45

$16.300 \quad 43$

$14.900 \quad 48$

$3.500 \quad 8$

$1.500 \quad 10$

$16.700 \quad 17$

$8.800 \quad 37$

$1.100 \quad 13$

$4.300 \quad 14$

\section{Hogere beroepen}

3031 bèta-onderzoekers, technische vakspecialisten

3631 hogere werktuigkundigen

3731 hogere electrotechnici

3931 architecten, geodeten e.a. hogere bouwkundigen

$\begin{array}{rrl}33.900 & 64 & \text { erg hoog* } \\ 1.200 & 7 & \text { laag } \\ 1.100 & 6 & \text { laag } \\ 7.700 & 28 & \text { hoog* }\end{array}$

" a antal baanopeningen is voor meer dan $50 \%$ het gevolg van de verwachte uitbreidingsvraag 
Tabel 4.2. Percentage werkenden jonger dan 30 jaar 'technische beroepen' 1990

ROA- beroepsklasse

percentage werkenden

code jonger dan 30 jaar

\section{Lagere beroepen}

3011 heftruck- en hefvorkchauffeurs $\quad 45$

3012 machinisten bouw en industrie $\quad 25$

3111 voedingsmiddelenbereiders $\quad 50$

3112 (zelfstandige) bakkers e.a. (industrieel) bakkerijpersoneel 44

3211 produktiepersoneel textielindustrie $\quad 42$

3212 stoffeerders, schoen- e.a. lederwarenmakers 33

3213 kleding- e.a. textiell- en bontproduktenmakers 36

3311 houtzagers, hout(waren)-, papier- en kartonmakers

3312 houtbewerkers, timmerlieden $\quad 31$

3411 drukkers, boekbinders, fotolaboranten 40

3511 produktiepersoneel chemische industrie $\quad 33$

3611 delfstoffen(belwerkers, metaalvervaardigers 44

3612 machinale metaalbewerkers $\quad 44$

3613 lassers, constructiewerkers, edelmetaalsmeden $\quad 44$

3614 machinebank- en plaatwerkers, gereedschaps- en modelmakers 42

3615 onderhoudsmonteurs, fietsen- en instrumentmakers $\quad 33$

3711 samenstellers electrotechnische produkten, kwaliteitscontroleurs 44

3811 produktiepersoneel bouwmaterialen-, glas- en aardewerkindustrie $\quad 47$

3911 metselaars, tegelzetters, straatmakers, stukadoors $\quad 39$

3912 betonwerkers, dakdekkers, isoleerders, glaszetters 42

3913 huis-, scheeps- en constructieschilders

3914 loodgieters, sanitair-installateurs en reparateurs

3915 overige bouwvaklieden, (spoor)weg- en reinigingswerkers 39

4011 laders, lossers, vul- en inpak(machinelbedienden $\quad 50$

4112 matrozen e.a. scheepsdek- en machinekamerpersoneel

4211 conducteurs, chauffeurs e.a. transportmiddelenbestuurders 28

\section{Middelbare beroepen}

3021 directeuren, bedrijfsleiders, leidinggevenden industrie 12

3022 technische en medische vertegenwoordigers

3023 technische tekenaars $\quad 47$

3024 technische analisten, amanuenses $\quad 42$

3621 auto-, motor- en bromfietsmonteurs $\quad 51$

3622 middelbare (scheeps)werktuigkundigen e.a. metaalkundigen 45

\begin{tabular}{lr}
3721 electriciens, electro- en telecom(onderhouds)monteurs & 45 \\
3921 bouwkundige technici, opzichters, werkvoorbereiders & 26 \\
\hline
\end{tabular}

4121 scheepsofficieren, loodsen, walinspecteurs
4321 vliegers, boordwerktuigkundigen, transportdienstleiders

\section{Hogere beroepen}

3031 beta-onderzoekers, technische vakspecialisten

3631 hogere werktuigkundigen

3731 hogere electrotechnici

3931 architecten, geodeten e.a. hogere bouwkundigen

- onbekend 
Tabel 4.3. Conjunctuurgevoeligheid 'technische beroepen'

ROA- beroepsklasse

conjunctuur-

typering

code

indicator

Lagere beroepen

3011 heftruck- en hefvorkchauffeurs

1,84

2,41

1,23

3012 machinisten bouw en industrie

3111 voedingsmiddelenbereiders

3112 (zelfstandige) bakkers e.a. (industrieel) bakkerijpersoneel

1,12

3,79

3211 produktiepersoneel textielindustrie

2,53

3212 stoffeerders, schoen- e.a. lederwarenmakers

3,41
1,97

3213 kleding-e.a. textiel- en bontproduktenmakers

2,86

3312 houtbewerkers, timmerlieden

3411 drukkers, boekbinders, fotolaboranten

2,07

3511 produktiepersoneel chemische industrie

2,31

3611 delfstoffen(be)werkers, metaalvervaardigers

2,53

2.64

3612 machinale metaalbewerkers

2,63

3613 lassers, constructiewerkers, edelmetaalsmeden

2,39

3614 machinebank- en plaatwerkers, gereedschaps- en modelmakers

2,03

3615 onderhoudsmonteurs, fietsen- en instrumentmakers

3711 samenstellers electrotechnische produkten, kwaliteitscontroleurs

2,88

2,46

3811 produktiepersoneel bouwmaterialen-, glas- en aardewerkindustrie

3911 metselaars, tegelzetters, straatmakers, stukadoors

3,43

3912 betonwerkers, dakdekkers, isoleerders, glaszetters

3,33

3,40

3913 huis-, scheeps- en constructieschilders

3,17

3914 loodgieters, sanitair-installateurs en reparateurs

3915 overige bouwvaklieden, (spoor/weg-en reinigingswerkers

2,24

4011 laders, lossers, vul- en inpak(machine)bedienden

1,69

4112 matrozen e.a. scheepsdek- en machinekamerpersoneel

1,51

4211 conducteurs, chauffeurs e.a. transportmiddelenbestuurders

1,31

gemiddeld

groot

klein

klein

erg groot

groot

erg groot

gemiddeld

erg groot

gemiddeld

groot

groot

erg groot

erg groot

groot

gemiddeld

erg groot

groot

erg groot

erg groot

erg groot

erg groot

groot

gemiddeld

gemiddeld

Middelbare beroepen

3021 directeuren, bedrijfsleiders, leidinggevenden industrie

2,11

gemiddeld

3022 technische en medische vertegenwoordigers

2,01

3023 technische tekenaars

1,88

3024 technische analisten, amanuenses

1,42

3621 auto-, motor-en bromfietsmonteurs

1,97

2,62

3721 electriciens, electro- en telecom(onderhouds)monteurs

3921 bouwkundige technici, opzichters, werkvoorbereiders

2,01

klein

4121 scheepsofficieren, loodsen, walinspecteurs

1,22

1,45

gemiddeld

gemiddeld

gemiddeld

klein

gemiddeld

erg groot

gemiddeld

klein

4321 vliegers, boordwerktuigkundigen, transportdienstleiders

klein

Hogere beroepen

3031 beta-onderzoekers, technische vakspecialisten

1,67

2,19

gemiddeld

3631 hogere werktuigkundigen

2,53

groot

3731 hogere electrotechnici

3931 architecten, geodeten e.a. hogere bouwkundigen

1,42

groot

klein 
gelijk of lager dan het gemiddelde. Voor 7 beroepsklassen is het aandeel jongeren onbekend ${ }^{27}$. Geconcludeerd kan worden dat met name voor de lagere technische beroepen de afhankelijkheid van schoolverlaters vrij groot is.

\section{Conjunctuurgevoeligheid}

In tabel 4.3. is de conjunctuurgevoeligheid van de technische beroepen weergegeven. Het blijkt dat de werkgelegenheidssituatie in veel technische beroepen sterk aan conjunctuurschommelingen onderhevig is. Een uitzondering wordt gevormd door de beroepsklassen 'voedingsmiddelenbereiders', '(zelfstandige) bakkers e.a. (industrieel) bakkerijpersoneel', 'auto-, motor- en bromfietsmonteurs', 'architecten, geodeten e.a. hogere bouwkundigen' en de meeste transportberoepen, waarvoor de conjunctuurgevoeligheid van de werkgelegenheid relatief klein is. Vooral bij de technische beroepen op lager en middelbaar niveau is er sprake van een weinig stabiele werkgelegenheidssituatie. Bij de hogere technische beroepen heeft de conjunctuurindicator een gemiddelde waarde.

\subsection{De marktpositie van technische opleidingen}

In deze paragraaf wordt nader ingegaan op de marktpositie van de technische opleidingen. In totaal worden tien ROA-opleidingstypen tot de 'technische opleidingen' gerekend: twee LBO-, drie MBO-, drie HBO- en twee WO-opleidingstypen. Evenals in hoofdstuk 3 wordt de marktpositie van de opleidingstypen belicht aan de hand van de huidige werkloosheid, de toekomstige arbeidsmarktperspectieven, de uitwijkmogelijkheden en de mate van onderbenutting, waarbij eerst ook een beeld zal worden gegeven van de verwachte baanopeningen (zie hoofdstuk 2).

\section{Baanopeningen}

Tabel 4.4. geeft een overzicht van het verwachte aantal baanopeningen voor de technische opleidingen in de periode 1989-1994. Daaraan is een typering toegevoegd, die aangeeft hoe groot het verwachte relatieve aantal baanopeningen is in verhouding tot het algehele beeld. De opleidingstypen waarvoor het totaal aantal baanopeningen voor meer dan $50 \%$ het gevolg is van de verwachte werkgelegenheidsontwikkeling, zijn aangeduid met een "*'.

Voor de technische opleidingen op LBO- en MBO-niveau wordt een relatief weinig baanopeningen verwacht. De technische opleidingen in het hoger onderwijs hebben daarentegen naar verwachting een relatief (erg) groot aantal baanopeningen. De uitzondering wordt gevormd door de vervoersopleidingen op zowel LBO-, MBO- als HBO-niveau, waarvoor het verwachte aantal baanopeningen ongeveer in overeenstemming is met het gemiddelde voor alle opleidingstypen. Met uitzondering van de opleidingstypen 'LBO Technisch', 'MBO Technisch Laboratorium' en 'MBO Haven \& Vervoer' hebben de verwachte baanopeningen voornamelijk

27. Deze percentages zijn onbekend vanwege de restricties die het CBS stelt bij het publiceren van EBB-gegevens. 
betrekking op de uitbreidingsvraag. Het 'LBO Technisch' is de enige van de genoemde opleidingen waarvoor de toekomstige vraag naar nieuwkomers alleen wordt veroorzaakt door de vervangingsvraag. Naar verwachting neemt het aantal werkenden met deze opleidingsachtergrond in de periode 1989-1994 af.

Tabel 4.4. Baanopeningen 'technische opleidingen' 1989-1994 labsolute aantallen en als percentage van het aantal werkenden in 1989)

Opleidingstype

baanopeningen

aantal \% typering

LBO Technisch

85.700

16

laag

LBO Haven \& Vervoer

7.30022 gemiddeld *

MBO Technisch Laboratorium

1.300

laag

MBO Technisch

90.900

9

12.300

13

laag*

MBO Haven \& Vervoer

8.400

27

35.300

32

gemiddeld

HBO Technisch Laboratorium

7.000

hoog *

HBO Technisch

16.900

30

hoog*

HBO Vervoer

21.600

26

gemiddeld *

WO Wis-/Natuurkunde

41

erg hoog ${ }^{*}$

wo Technisch

35 hoog"

* = aantal baanopeningen is voor meer dan $50 \%$ het gevolg van de verwachte uitbreidingsvraag

Bron: ROA

\section{Huidige werkloosheid}

Tabel 4.5. Werkloosheid "technische opleidingen" april 1991 (bemiddelingsbestand zonder baan)

Opleidingstype

werkloosheid

$\%$

$\begin{array}{lr}\text { LBO Technisch } & 8 \\ \text { LBO Haven \& Vervoer } & 3 \\ \text { MBO Technisch Laboratorium } & 3 \\ \text { MBO Technisch } & 2 \\ \text { MBO Haven \& Vervoer } & 1 \\ \text { HBO Technisch Laboratorium } & 3 \\ \text { HBO Technisch } & 2 \\ \text { HBO Vervoer } & 2 \\ \text { WO Wis-/Natuurkunde } & 4 \\ \text { WO Technisch } & 2 \\ \text { Totaal (alle opleidingstypen) } & 8\end{array}$

Bron: Arbeidsvoorzieningsorganisatie/ROA 
Een belangrijke indicatie van de relatieve marktpositie van de technische opleidingen kan worden verkregen op basis van de huidige ( $k$ wantitatieve) verhouding tussen vraag en aanbod op de arbeidsmarkt voor de desbetreffende opleidingstypen. In tabel 4.5. is een overzicht gegeven van de werkloosheid voor de technische opleidingen per april 199128. Het blijkt dat voor vrijwel alle geselecteerde opleidingstypen de werkloosheid ver onder het gemiddelde ligt. Een uitzondering wordt gevormd door het opleidingstype 'LBO Technisch', waarvoor het werkloosheidspercentage gelijk is aan het landelijk gemiddelde.

\section{Toekomstige arbeidsmarktperspectieven}

Als gevolg van de hiervoor reeds besproken vraagontwikkeling, maar ook als gevolg van de toekomstige ontwikkelingen in het arbeidsaanbod van nieuwkomers kan in de nabije toekomst een verandering optreden in de relatieve schaarsteverhoudingen op de arbeidsmarkt. Tabel 4.6. geeft aan wat naar verwachting de toekomstige arbeidsmarktperspectieven voor de technische opleidingen zijn.

Tabel 4.6. Toekomstig arbeidsmarktperspectief "technische opleidingen' 1989-1994

Opleidingstype

indicator toekomstige

arbeidsmarktsituatie typering

matig
goed
redelijk
matig
goed
goed
goed
goed
goed
goed

Bron: ROA

Voor vrijwel alle geselecteerde opleidingstypen komt de verwachte toekomstige arbeidsmarktsituatie overeen met de huidige situatie. Een vitzondering betreft met name het opleidingstype 'MBO Technisch'. Terwijl de huidige werkloosheid laag is, worden de toekomstige arbeidsmarktperspectieven voor dit opleidingstype als matig getypeerd. Overigens kan het beeld voor de diverse richtingen binnen 'MBO Technisch' daarbij sterk verschillend zijn ${ }^{29}$. Opvallend is verder

28. Zoals reeds eerder in dit rapport is opgemerkt, geven de gepresenteerde werkloosheidspercentages slechts een indicatie van de relatieve ernst van de werkloosheid, c.q. krapte op de arbeidsmarkt voor de verschillende opleidingstypen.

29. Het CPB verwacht een relatief krappe arbeidsmarkt voor de ruimer gedefinieerde opleidingscategorie middelbaar technisch/agrarisch. Zie hoofdstuk 1 van dit rapport voor een vergelijking van de ROA-prognoses met de CPB-prognoses. 
dat voor alle technische opleidingen op HBO- en WO-niveau een goed toekomstig arbeidsmarktperspectief wordt verwacht.

\section{Uitwijkmogelijkheden}

Behalve door het toekomstig arbeidsmarktperspectief wordt de relatieve marktpositie van de technische opleidingen ook bepaald door het flexibiliteitspotentieel van de afgestudeerden van deze opleidingstypen. In tabel 4.7. wordt met behulp van de Gini-Hirschman spreidingsindex een overzicht gegeven van de uitwijkmogelijkheden van de technisch opgeleiden. De uitwijkmogelijkheden naar beroepen op een relatief te laag functieniveau worden daarbij buiten beschouwing gelaten.

Tabel 4.7. Uitwijkmogelijkheden op een aansluitend of hoger functieniveau 'technische opleidingen' 1990

$\begin{array}{lcc}\text { LBO Technisch } & 0,97 & \text { erg groot } \\ \text { LBO Haven \& Vervoer } & 0,96 & \text { erg groot } \\ \text { MBO Technisch Laboratorium } & 0,68 & \text { erg klein } \\ \text { MBO Technisch } & 0,97 & \text { erg groot } \\ \text { MBO Haven \& Vervoer } & 0,95 & \text { groot } \\ \text { HBO Technisch Laboratorium } & 0,85 & \text { gemiddeld } \\ \text { HBO Technisch } & 0,96 & \text { erg groot } \\ \text { HBO Vervoer } & 0,95 & \text { groot } \\ \text { WO Wis-/Natuurkunde } & 0,91 & \text { groot } \\ \text { WO Technisch } & 0,96 & \text { erg groot }\end{array}$

Bron: ROA

De spreiding van arbeidskrachten over de verschillende beroepsgroepen blijkt voor de technische opleidingen in het algemeen hoog tot erg hoog te zijn. Dit betekent dat de afgestudeerden van deze opleidingstypen in veel verschillende beroepen actief (kunnen) zijn, waardoor zij minder gevoelig zijn voor (conjuncturele) werkgelegenheidsschommelingen. Een uitzondering wordt gevormd door de opleidingstypen 'MBO Technisch Laboratorium' en 'HBO Technisch Laboratorium' waar de beroepenspreiding respectievelijk erg laag en gemiddeld is. Overigens moet bij de geconstateerde grote vitwijkmogelijkheden van de technisch opgeleiden de kanttekening worden gemaakt dat de opleidingstypen vaak betrekking hebben op een breed scala van meer specifieke opleidingsrichtingen. Het is derhalve niet uitgesloten dat de vitwijkmogelijkheden op de arbeidsmarkt voor de afgestudeerden in een specifieke vakrichting kleiner zijn dan de uitkomsten hier aangeven.

\section{Onderbenutting}

Naast de bovengenoemde uitwijkmogelijkheden kunnen de opgeleiden in principe ook terecht 
komen in beroepen op een lager functieniveau. Dit betekent echter een onderbenutting van de kwalificaties waarover men beschikt, hetgeen als een negatieve indicatie voor de marktpositie van het desbetreffende opleidingstype mag worden gezien. Tabel 4.8. geeft aan voor welk deel van de arbeidskrachten met een technische opleidingsachtergrond er sprake is van onderbenutting.

In de tabel is een duidelijke tweedeling te herkennen. Enerzijds kunnen de HBO- en WOopleidingen worden getypeerd als opleidingen, waarbij slechts een gering percentage van de beroepsbeoefenaren een functie onder het niveau van de opleiding uitoefent. Het opleidingstype 'HBO Vervoer' vormt hierop een uitzondering. Anderzijds geldt voor de LBO- en MBO-opgeleiden dat het onderbenuttingspercentage ongeveer gelijk aan het gemiddelde is. Een gunstige uitzondering wordt hierbij gevormd door het opleidingstype 'MBO Technisch Laboratorium'. De opleidingstypen 'MBO Haven \& Vervoer' en vooral 'LBO Haven \& Vervoer' vormen daarentegen een uitzondering in ongunstige zin.

Tabel 4.8. Percentage onderbenutting 'technische opleidingen' 1990

$\begin{array}{lll}\text { Opleidingstype } & \begin{array}{l}\text { percentage } \\ \text { onderbenutting }\end{array} & \text { typering }\end{array}$

$\begin{array}{lcc}\text { LBO Technisch } & 40 & \text { gemiddeld } \\ \text { LBO Haven \& Vervoer } & 78 & \text { erg hoog } \\ \text { MBO Technisch Laboratorium } & 16 & \text { laag gemiddeld } \\ \text { MBO Technisch } & 36 & \text { hoog } \\ \text { MBO Haven \& Vervoer } & 46 & \text { laag } \\ \text { HBO Technisch Laboratorium } & 10 & \text { laag } \\ \text { HBO Technisch } & 13 & \text { gemiddeld } \\ \text { HBO Vervoer } & 40 & \text { laag } \\ \text { WO Wis-/Natuurkunde } & 14 & 16 \\ \text { WO Technisch } & \text { laag }\end{array}$

Bron: ROA

In het algemeen kan.worden gesteld dat de marktpositie van de technische opleidingen op HBOen WO-niveau erg goed is. Voor de LBO- en MBO-opleidingen geldt echter een gedifferentieerder beeld. Voor 'LBO Technisch' is de huidige werkloosheid ongeveer gelijk aan het landelijk gemiddelde en wordt voor de nabije toekomst een matig arbeidsmarktperspectief verwacht. Wel zijn de uitwijkmogelijkheden voor dit opleidingstype erg groot, al kan daarbij de kanttekening worden geplaatst dat er grote verschillen bestaan tussen de diverse meer specifieke vakrichtingen. Ook voor 'MBO Technisch' geldt een dergelijk beeld, met dit verschil dat de huidige werkloosheid voor dit opleidingstype als laag kan worden getypeerd. Voor het opleidingstype 'MBO Technisch Laboratorium' is de huidige werkloosheid laag en wordt het toekomstige arbeidsmarktperspectief als redelijk getypeerd. De uitwijkmogelijkheden van dit opleidingstype zijn weliswaar gering, maar het percentage arbeidskrachten dat een functie op een te laag niveau uitoefent, is relatief laag. Voor het opleidingstype 'MBO Haven \& Vervoer' 
$-55-$

geldt dat de marktpositie als goed kan worden getypeerd. Deze opleiding wordt gekenmerkt door een lage werkloosheid en een naar verwachting goed toekomstig arbeidsmarktperspectief. Ook de uitwijkmogelijkheden naar andere beroepsgroepen zijn voor deze groep opgeleiden hoog. Voor het opleidingstype 'LBO Haven \& Vervoer' geldt eenzelfde beeld, waarbij wel moet worden opgemerkt dat een groot deel van de arbeidskrachten met deze opleidingsachtergrond werkzaam is op functies waarbij er sprake is van onderbenutting van de gevolgde opleiding. 


\section{SEXE, ONDERWIJS EN ARBEIDSMARKT}

\subsection{Inleiding}

In dit hoofdstuk wordt ingegaan op de verschillen in de arbeidsmarktpositie van mannen en vrouwen. Behalve op enkele algemene verschillen tussen de positie van mannen en vrouwen op de arbeidsmarkt, wordt daarbij ook ingegaan op de marktpositie van enkele typische 'vrouwenberoepen' en 'vrouwenopleidingen'.

Het hoofdstuk is als volgt ingedeeld. Eerst worden in paragraaf 5.2. de verschillen tussen mannen en vrouwen in arbeidsmarktparticipatie aangegeven. Voorts worden in deze paragraaf de sexe-verschillen in de beroepen- en opleidingenstructuur van de werkgelegenheid geanalyseerd. Daarna wordt in paragraaf 5.3. een aantal typische 'vrouwenberoepen' geselecteerd, waarvan de marktpositie nader wordt belicht. Paragraaf 5.4. geeft tenslotte een beschrijving van de marktpositie van traditionele 'vrouwenopleidingen'.

\subsection{Participatie en segregatie}

\section{Participatie}

Sinds de jaren zestig is het percentage vrouwen dat zich aanbiedt op de arbeidsmarkt sterk gestegen. Deze participatie op de arbeidsmarkt wordt meestal uitgedrukt in de zogenaamde 'participatiegraad': het aandeel van de beroepsbevolking in de totale bevolking van 15 tot 65 jaar. Mannen en vrouwen zijn wat betreft hun participatie op de arbeidsmarkt in de afgelopen decennia in belangrijke mate naar elkaar toegegroeid. Terwijl in 1960 de participatiegraad voor mannen $90 \%$ en voor vrouwen $26 \%$ was, bedraagt deze in 1990 respectievelijk $81 \%$ en $54 \%$ (zie Ministerie van Sociale Zaken en Werkgelegenheid, 1990 en tabel 5.1.).

Tabel 5.1. Participatiegraad naar opleidingsniveau en geslacht 1990

\begin{tabular}{lcc}
\hline Opleidingsniveau & \multicolumn{2}{c}{ participatiegraad } \\
& $\begin{array}{c}\text { mannen } \\
\%\end{array}$ & vrouwen \\
\hline Basisonderwijs & & 30,7 \\
MAVO en onderbouw HAVONWO & 65,7 & 47,0 \\
LBO & 62,6 & 47,8 \\
Bovenbouw HAVO/VWO & 86,3 & 55,8 \\
MBO & 62,1 & 66,8 \\
HBO & 89,5 & 76,9 \\
WO & 92,2 & 85,9 \\
Totaal (incl. opleidingsniveau onbekendl & 94,4 & 54,1 \\
\hline
\end{tabular}

Bron: $\mathrm{CBS} / \mathrm{ROA}$ 
Bij de mannen is de participatiegraad gedaald door enerzijds een hogere onderwijsparticipatie van jongere mannen en anderzijds een toename van het aantal (oudere) mannen dat arbeidsongeschikt is of vervroegd is uitgetreden. De participatie van mannen tussen de 25 en 50 jaar is nagenoeg niet veranderd. De stijgende participatie van vrouwen heeft zich vooral in de middelste leeftijdsklassen bij met name gehuwde vrouwen voltrokken. Het betreft hier met andere woorden vooral de (gehuwde) vrouwen in de 'vruchtbare' levensfase (zie Bruyn-Hundt, 1988).

Uit tabel 5.1. blijkt duidelijk dat er een positieve samenhang bestaat tussen de participatiegraad en het opleidingsniveau. Vooral voor vrouwen geldt dat een hoog opleidingsniveau gepaard gaat met een relatief hoge participatie. Van de vrouwen met basisonderwijs als hoogst behaald onderwijsniveau kan slechts ongeveer $31 \%$ worden gerekend tot de beroepsbevolking. Voor de vrouwen met een universitaire opleiding bedraagt de participatiegraad $86 \%$. Bij de mannen is dit verschil naar opleidingsniveau minder extreem, respectievelijk $66 \%$ voor de mannen met uitsluitend basisonderwijs en $94 \%$ voor de mannen met een universitaire opleiding. Derhalve kan worden geconcludeerd dat het verschil tussen mannen en vrouwen in arbeidsmarktparticipatie zich vooral manifesteert op de lagere opleidingsniveaus.

De participatiegraad geeft overigens maar een beperkt beeld van de verschillen tussen mannen en vrouwen in de deelname aan het arbeidsproces. Bij deze indicator wordt immers geen rekening gehouden met het feit dat vrouwen vaker dan mannen in deeltijd werken. Hierdoor is de feitelijke deelname van vrouwen aan het arbeidsproces geringer dan men op basis van de participatiegraad zou vermoeden. Later in dit hoofdstuk wordt op het deeltijd-aspect teruggekomen.

\section{Segregatie}

De verschillen in arbeidsmarktpositie tussen mannen en vrouwen hebben niet alleen te maken met verschillen in de participatiegraad, maar ook met het soort werk. Mannen en vrouwen komen namelijk in verschillende beroepen terecht. Deze segregatie tussen mannen- en vrouwenberoepen kan tot uitdrukking worden gebracht met behulp van een index. Deze segregatie-index geeft aan hoe groot de som is van het percentage mannelijke beroepsbeoefenaren en het percentage vrouwelijke beroepsbeoefenaren dat van beroep dient te veranderen om voor mannen en vrouwen een gelijke beroepenstructuur te bewerkstelligen (zie ook Siegers, 1979). De index kan een waarde aannemen tussen 0 en 100.

De beroepssegregatie blijkt in 1990 gelijk te zijn aan $60^{30}$. De daling van de beroepssegregatie, zoals die reeds door Van Mourik en Siegers (1988) is geconstateerd, lijkt zich daarmee voort te zetten. Wel moet daarbij de kanttekening worden gemaakt dat de ontwikkeling van de segregatie in de tijd enigszins kan zijn vertekend door de overgang van de AKT- naar de EBBgegevens.

30. De segregatie-index is bepaald op het niveau van CBS 3-digit beroepsgroepen. 
Voor een belangrijk deel heeft deze beroepssegregatie te maken met het feit dat mannen en vrouwen met een verschillende opleidingsachtergrond de arbeidsmarkt betreden (zie Groot, 1990). Deze verschillen in kwalificatie hebben niet zozeer betrekking op het bereikte opleidingsniveau, maar vooral op de gevolgde opleidingsrichting. Vrouwen zijn oververtegenwoordigd in de algemeen vormende, pedagogische, economisch-administratieve en verzorgende opleidingen. Daarentegen hebben mannen vaker een technische of agrarische opleiding gevolgd. In tabel 5.2 is de opleidingssegregatie ${ }^{31}$ van de werkende bevolking gepresenteerd. Het blijkt dat de som van het percentage mannelijke arbeidskrachten en het percentage vrouwelijke arbeidskrachten dat een andere opleidingskwalificatie zou moeten hebben om een gelijke geslachtsverdeling over de opleidingstypen te verkrijgen, $46 \%$ bedraagt. Daarbij kan worden opgemerkt dat de opleidingssegregatie lager is bij de hogere opleidingsniveaus.

Tabel 5.2. Opleidingssegregatie per opleidingsniveau 1990

Bron: ROA

Afsluitend kan worden geconcludeerd dat er in het algemeen forse verschillen zijn in de arbeidsmarktpositie van mannen en vrouwen. Deze verschillen komen tot uitdrukking in zowel de participatiegraad, als het soort werk dat men uitoefent. De verschillen manifesteren zich vooral op de lagere opleidingsniveaus. De beroepssegregatie tussen mannen en vrouwen vindt daarbij voor een belangrijk deel haar oorsprong in een voorsortering binnen het onderwijs, waardoor mannen en vrouwen zich met uiteenlopende kwalificaties op de arbeidsmarkt aanbieden.

\subsection{De marktpositie van vrouwenberoepen}

In deze paragraaf komen enkele kenmerken aan de orde die de marktpositie van typische 'vrouwenberoepen' bepalen. Het gaat hier om de beroepsklassen waarin $60 \%$ of meer van de beroepsbeoefenaren in 1990 uit vrouwen bestaat (zie ook Siegers, 1979). Achtereenvolgens wordt daarbij ingegaan op de verwachte baanopeningen, de afhankelijkheid van schoolverlaters en de conjunctuurgevoeligheid van de werkgelegenheid (zie ook hoofdstuk 2 en 3). Eerst wordt echter een beeld geschetst van het percentage vrouwen en het percentage deeltijdwerkenden in de diverse vrouwenberoepen. Uitdrukkelijk moet worden opgemerkt dat de indicatoren die in

31. De segregatie-index heeft betrekking op het niveau van ROA-opleidingstypen. 
deze paragraaf aan de orde komen niet alleen op de vrouwelijke arbeidskrachten betrekking hebben, maar ook op de werkende mannen in de desbetreffende "vrouwenberoepen".

De geselecteerde beroepsklassen en de ontwikkeling van het percentage vrouwen in de perioden 1979-1985 en 1987-1990 staan, geordend naar het percentage vrouwen in 1990, vermeld in tabel 5.3. Het is daarbij van belang om op te merken dat bij de interpretatie van de verschillen tussen 1985 en 1987 rekening moet worden gehouden met de trendbreuk in de data als gevolg van de overgang van AKT- naar EBB-gegevens.

Tabel 5.3. Percentage vrouwen 'vrouwenberoepen' 1979-1985 en 1987-1990

ROA- beroepsklasse code percentage vrouwen

$\begin{array}{llll}1979 & 1985 & 1987 & 1990\end{array}$

5023 dokters-, tandarts- en dierenartsassistenten

6122 secretaressen, typisten

8212 kinder-, gezins-, bejaardenverzorgenden e.a. verzorgend personeel

5022 leerling-verpleegkundigen, zieken- en kraamverzorgenden

3213 kleding- e.a. textiel- en bontproduktenmakers

8221 kappers, schoonheidsspecialisten

5021 gediplomeerde verpleegkundigen, verloskundigen

6126 telefonisten, balie-employées, enquêteurs e.d.

5024 apothekersassistenten, opticiens, orthoptisten

5025 EEG-laboranten, keurmeesters, diëtisten, logopedisten, pedicuren e.d.

8211 portiers, schoonmaak- e.a. lager dienstverlenend personeel

5032 radiologische, medische en biologische laboranten

6123 bibliotheekassistenten

5031 fysio-, arbeids- e.a. bewegingstherapeuten

0131 leerkrachten basis- en speciaal onderwijs

totaal (alle beroepsklassen)

$\begin{array}{rrrr}98 & 99 & 100 & 100 \\ 97 & 96 & 96 & 98 \\ 98 & 98 & 98 & 98 \\ 86 & 86 & 87 & 90 \\ 83 & 84 & 83 & 84 \\ 67 & 77 & 80 & 83 \\ 81 & 78 & 79 & 82 \\ 69 & 76 & 77 & 81 \\ 78 & 82 & 75 & 80 \\ & & & \\ 76 & 71 & 74 & 77 \\ 72 & 74 & 79 & 76 \\ 58 & 59 & 58 & 75 \\ 52 & 54 & 62 & 70 \\ 65 & 62 & 64 & 67 \\ 64 & 63 & 63 & 66 \\ & & & \\ 30 & 34 & 36 & 38\end{array}$

Bron: CBS/ROA

Het blijkt dat in 1990 vijftien van de 93 beroepsklassen een percentage vrouwen van $60 \%$ of meer hebben. Deze vijftien beroepsklassen vertegenwoordigen circa $40 \%$ van de totale werkgelegenheid voor vrouwen. Het percentage vrouwen varieert in 1990 van $100 \%$ bij de 'dokters- tandarts- en dierenartsassistenten' tot $66 \%$ bij de 'leerkrachten basis- en speciaal onderwijs'. Bij een aantal vrouwenberoepen kan een groeiend aandeel van vrouwen in het totaal aantal werkenden worden geconstateerd. Dit geldt met name voor de 'kappers, schoonheidsspecialisten', 'telefonisten, balie-employées, enquêteurs e.d.', 'radiologische, medische en biologische laboranten' en 'bibliotheekassistenten'. Dit duidt derhalve op een toenemende segregatie voor de desbetreffende beroepsklassen.

Bij de bespreking van de participatiegraad in paragraaf 5.2 . is reeds opgemerkt dat vrouwen relatief vaker in deeltijd werken dan mannen. Tabel 5.4. geeft een overzicht van het percentage 
deeltijders $^{32}$ in de geselecteerde vrouwenberoepen in 1990. Conform de verwachtingen is het percentage deeltijders in de vrouwenberoepen relatief hoog. Voor alle geselecteerde beroepsklassen geldt dat het percentage deeltijders boven het gemiddelde van alle beroepsklassen ligt. Bij de beroepsklassen 'kinder-, gezins-, bejaardenverzorgenden e.a. verzorgend personeel' en 'portiers, schoonmaak- e.a. lager dienstverlenend personeel' is het aandeel deeltijders met ongeveer $75 \%$ zelfs zeer hoog.

Tabel 5.4. Percentage deeltijdwerkenden 'vrouwenberoepen' 1990

ROA- beroepsklasse

percentage

code

deeltijders

5023 dokters-, tandarts- en dierenartsassistenten 43

6122 secretaressen, typisten

8212 kinder-, gezins-, bejaardenverzorgenden e.a. verzorgend personeel 78

5022 leerling-verpleegkundigen, zieken- en kraamverzorgenden 36

3213 kleding- e.a. textiel- en bontproduktenmakers 48

8221 kappers, schoonheidsspecialisten

5021 gediplomeerde verpleegkundigen, verloskundigen $\quad 37$

6126 telefonisten, balie-employées, enqueteurs e.d. 46

5024 apothekersassistenten, opticiens, orthoptisten

5025 EEG-laboranten, keurmeesters, diettisten, logopedisten, pedicuren e.d.

8211 portiers, schoonmaak- e.a. lager dienstverlenend personeel 73

5032 radiologische, medische en biologische laboranten

6123 bibliotheekassistenten 43

5031 fysio-, arbeids- e.a. bewegingstherapeuten 45

0131 leerkrachten basis" en speciaal onderwijs 36

totaal (alle beroepsklassen) 28

$=$ onbekend

Bron: CBS/ROA

\section{Baanopeningen}

In tabel 5.5. is voor de vrouwenberoepen het verwachte aantal baanopeningen in de prognoseperiode 1989-1994 weergegeven. Met behulp van een kwalitatieve typering is aangegeven hoe dit verwachte aantal baanopeningen zich verhoudt tot het gemiddelde van alle beroepsklassen. De beroepsklassen waarbij het grootste deel van de totale vraag naar nieuwkomers het gevolg is van een toenemende werkgelegenheid zijn daarbij aangemerkt met een '*'.

32. Het gaat hier om de werkenden met een werkweek van minder dan 30 uur. Voor twee beroepsklassen kan het aandeel deeltijd-werkenden niet worden gepubliceerd vanwege de publikatierestricties van het CBS. 
Tabel 5.5. Baanopeningen 'vrouwenberoepen' 1989-1994 (absolute aantallen en als percentage van het aantal werkenden in 1989)

ROA- beroepsklasse

code

baanopeningen

aantal $\%$ typering
5023 dokters-, tandarts- en dierenartsassistenten

6122 secretaressen, typisten

8212 kinder-, gezins, bejaardenverzorgenden e.a. verzorgend personeel

5022 leerling-verpleegkundigen, zieken- en kraamverzorgenden

3213 kleding- e.a. textiel- en bontproduktenmakers

8221 kappers, schoonheidsspecialisten

5021 gediplomeerde verpleeglkundigen, verloskundigen

6126 telefonisten, balie-employées, enquêteurs e.d.

5024 apothekersassistenten, opticiens, orthoptisten

5025 EEG-laboranten, keurmeesters, diëtisten, logopedisten, pedicuren e.d.

8211 portiers, schoonmaak- e.a. lager dienstverlenend personeel

5032 radiologische, medische en biologische laboranten

6123 bibliotheekassistenten

5031 fysio-, arbeids- e.a. bewegingstherapeuten

0131 leerkrachten basis- en speciaal onderwijs

$\begin{array}{rrl}5.900 & 26 & \text { gemiddeld } \\ 18.500 & 12 & \text { laag } \\ 67.200 & 40 & \text { erg hoog* } \\ 31.500 & 29 & \text { hoog } \\ 6.300 & 23 & \text { gemiddeld } \\ 7.600 & 21 & \text { gemiddeld } \\ 21.700 & 18 & \text { gemiddeld } \\ 9.500 & 11 & \text { laag } \\ 2.100 & 15 & \text { gemiddeld } \\ & & \\ 7.400 & 24 & \text { gemiddeld } \\ 76.700 & 32 & \text { hoog* } \\ 3.300 & 13 & \text { laag } \\ 3.600 & 14 & \text { gemiddeld } \\ 8.100 & 21 & \text { gemiddeld } \\ 17.400 & 15 & \text { gemiddeld }\end{array}$

- aantal baanopeningen is voor meer dan $50 \%$ het gevolg van de verwachte uitbreidingsvraag

Bron: ROA

Voor de vrouwenberoepen 'kinder-, gezins-, bejaardenverzorgenden e.a. verzorgend personeul', 'leerling-verpleegkundigen, zieken- en kraamverzorgenden' en 'portiers, schoonmaak e.a. lager dienstverlenend personeel' is het verwachte aantal baanopeningen zowel absoluut als relatief gezien (erg) hoog. Voor de overige vrouwenberoepen geldt daarentegen dat de verwachte totale vraag naar nieuwkomers gemiddeld of relatief laag is.

Opvallend is dat voor slechts 4 van de 15 geselecteerde vrouwenberoepen, te weten 'kinder-, gezins-, bejaardenverzorgenden e.a. verzorgend personeel', 'kappers, schoonheidsspecialisten', apothekersassistenten, opticiens, orthoptisten' en 'portiers, schoonmaak- e.a. lager dienstverlenend personeel', de baanopeningen voornamelijk tot stand komen als gevolg van de verwachte uitbreidingsvraag. Voor de overige 11 beroepsklassen geldt derhalve dat de vervangingsvraag de grootste component van de totale vraag naar nieuwkomers vormt.

\section{Afhankelijkheid van schoolverlaters}

Tabel 5.6. geeft een overzicht van het percentage werkenden jonger dan 30 jaar in de verschillende vrouwenberoepen. Hiermee wordt aangegeven hoe sterk de beroepsklassen afhankelijk zijn van de instroom van schoolverlaters voor de vervulling van de vraag naar nieuwkomers. Voor de vrouwenberoepen varieert het aandeel werkenden jonger dan 30 jaar van $18 \%$ voor de beroepsklasse 'leerkrachten basis- en speciaal onderwijs' tot $57 \%$ voor de 
beroepsklasse 'dokters-, tandarts- en dierenartsassistenten'. Ook in de beroepsklassen 'kappers, schoonheidsspecialisten' $(56 \%)$ en 'leerling-verpleegkundigen, verloskundigen' $(55 \%)$ is meer dan de helft van de werkenden jonger dan 30 jaar. Ter vergelijking: het aandeel jongeren in de totale werkgelegenheid bedraagt $35 \%$.

Geconcludeerd kan worden dat in de meeste geselecteerde vrouwenberoepen relatief veel jongeren werkzaam zijn. Dit maakt deze beroepsklassen relatief gevoelig voor de verwachte ontgroening van het aanbod op de arbeidsmarkt. Wel moet hierbij worden opgemerkt dat de instroom op de arbeidsmarkt, juist voor deze typische vrouwenberoepen, niet alleen betrekking kan hebben op schoolverlaters, maar ook op herintreders.

Tabel 5.6. Percentage werkenden jonger dan 30 jaar 'vrouwenberoepen' 1990

ROA- beroepsklasse

percentage werkenden

code

jonger dan 30 jaar

5023 dokters-, tandarts- en dierenartsassistenten $\quad 57$

6122 secretaressen, typisten

8212 kinder-, gezins-, bejaardenverzorgenden e.a. verzorgend personeel 32

5022 leerling-verpleegkundigen, zieken- en kraamverzorgenden 55

3213 kleding- e.a. textiel- en bontproduktenmakers

8221 kappers, schoonheidsspecialisten

5021 gediplomeerde verpleegkundigen, verloskundigen 35

6126 telefonisten, balie-employées, enquêteurs, e.d. 43

5024 apothekersassistenten, opticiens, orthoptisten

5025 EEG-laboranten, keurmeesters, diëtisten, logopedisten, pedicuren e.d. 27

8211 portiers, schoonmaak- e.a. lager dienstverlenend personeel 29

5032 radiologische, medische en biologische laboranten 43

6123 bibliotheekassistenten 39

5031 fysio-, arbeids- e.a. bewegingstherapeuten 29

0131 leerkrachten basis- en speciaal onderwijs 18

totaal (alle beroepsklassen) 35

Bron: CBS/ROA

\section{Conjunctuurgevoeligheid}

Tabel 5.7. laat zien hoe groot de conjunctuurgevoeligheid van de diverse vrouwenberoepen is. Het blijkt dat de werkgelegenheid in de geselecteerde beroepsklassen in het algemeen weinig aan conjunctuurschommelingen onderhevig is. Voor alle verzorgende vrouwenberoepen is de conjunctuurgevoeligheid ongeveer gelijk aan het landelijke gemiddelde. Enkele vrouwenberoepen hebben een relatief lage conjunctuurgevoeligheid. Voor de beroepsklasse 'kleding- e.a. textielen bontproduktenmakers' heeft de conjunctuurindicator een relatief erg hoge waarde. 
Tabel 5.7. Conjunctuurgevoeligheid 'vrouwenberoepen'

ROA- beroepsklasse

conjunctuur- typering code indicator

5023 dokters-, tandarts- en dierenartsassistenten

6122 secretaressen, typisten

8212 kinder-, gezins-, bejaardenverzorgenden e.a. verzorgend personeel

5022 leerling-verpleegkundigen, zieken- en kraamverzorgenden

3213 kleding-e.a. textiel- en bontproduktenmakers

8221 kappers, schoonheidsspecialisten

5021 gediplomeerde verpleegkundigen, verloskundigen

6126 telefonisten, balie-employées, enqueteurs, e.d.

5024 apothekersassistenten, opticiens, orthoptisten

5025 EEG-laboranten, keurmeesters, diëtisten, logopedisten, pedicuren e.d.

8211 portiers, schoonmaak- e.a. lager dienstverlenend personeel

5032 radiologische, medische en biologische laboranten

Bron: ROA

\subsection{De marktpositie van vrouwenopleidingen}

In deze paragraaf wordt ingegaan op de marktpositie van typische 'vrouwenopleidingen'. Daarbij wordt een opleidingstype als vrouwenopleiding getypeerd als minstens $60 \%$ van de werkenden met een dergelijke opleidingsachtergrond uit vrouwen bestaat. Achtereenvolgens komen in deze paragraaf de huidige werkloosheid, de toekomstige arbeidsmarktperspectieven, de uitwijkmogelijkheden en de mate van onderbenutting aan de orde (zie ook hoofdstuk 3). Eerst wordt echter een beeld gegeven van het verwachte aantal baanopeningen (zie ook hoofdstuk 2).

Tabel 5.8. Percentage vrouwen 'vrouwenopleidingen' 1990

MBO Verpleging \& Ziekenverzorging 90

$M B O$ Verzorgend

HBO Medisch Laboratorium

MBO Medisch Laboratorium 
De geselecteerde opleidingstypen met het percentage vrouwen in 1990 staan vermeld in tabel 5.8. Ook hier dient te worden opgemerkt dat de in deze paragraaf te bespreken marktpositie niet uitsluitend betrekking heeft op vrouwen, maar op alle werkenden met de desbetreffende opleidingsachtergrond. In totaal blijken 7 van de 49 opleidingstypen aan het selectiecriterium van minimaal $60 \%$ vrouwen te voldoen. Het betreft hier met name opleidingen in de medische en verzorgende richting. Het opleidingstype 'LBO Verzorgend' heeft met $91 \%$ het hoogste aandeel vrouwelijke arbeidskrachten. De in tabel 5.8. weergegeven opleidingstypen vertegenwoordigen ruim $30 \%$ van de totale werkgelegenheid van vrouwen.

\section{Baanopeningen}

In tabel 5.9. wordt een beeld gegeven van de verwachte baanopeningen voor de vrouwenopleidingen in de periode 1989-1994. Daarbij is tevens aangegeven of dit aantal baanopeningen als (erg) hoog, (erg) laag of gemiddeld kan worden getypeerd. De "*' bij deze typering geeft aan dat meer dan $50 \%$ van de baanopeningen het gevolg is van de verwachte werkgelegenheidsontwikkeling.

Tabel 5.9. Baanopeningen 'vrouwenopleidingen' 1989-1994 labsolute aantallen en als percentage van het aantal werkenden in 19891

Opleidingstype

aantal \begin{tabular}{c}
\multicolumn{2}{c}{ baanopeningen } \\
$\%$
\end{tabular}

LBO Verzorgend

MBO Verpleging \& Ziekenverzorging

MBO Verzorgend

HBO Medisch Laboratorium

MBO Medisch Laboratorium

HBO Verpleging \& Paramedisch

MBO Sociaal-Cultureel

$\begin{array}{rll}84.900 & 31 & \text { hoog * } \\ 41.800 & 22 & \text { gemiddeld * } \\ 111.700 & 46 & \text { erg hoog* } \\ 4.000 & 21 & \text { gemiddeld } \\ 5.600 & 22 & \text { gemiddeld * } \\ 10.700 & 14 & \text { laag * } \\ 13.900 & 33 & \text { hoog }\end{array}$

- aantal baanopeningen is voor meer dan $50 \%$ het gevolg van de verwachte uitbreidingsvraag.

Bron: ROA

Voor de opleidingstypen 'LBO Verzorgend' en vooral 'MBO Verzorgend' wordt zowel absoluut als relatief gezien een groot aantal baanopeningen verwacht. Het relatieve aantal baanopeningen is ook voor 'MBO Sociaal-Cultureel' naar verwachting hoog. Temeer daar voor de meeste vrouwenberoepen de baanopeningen hoofdzakelijk het gevolg zijn van de vervangingsvraag is het opvallend dat met uitzondering van 'HBO Medisch Laboratorium' het verwachte aantal baanopeningen bij de vrouwenopleidingen voornamelijk tot stand komt als gevolg van de uitbreidingsvraag. Voor een belangrijk deel is deze tegenstelling het gevolg van het feit dat bij de relatief grote 'verzorgende' vrouwenberoepen, net als bij de hier gepresenteerde resultaten naar opleidingstype, de verwachte uitbreidingsvraag groter is dan de verwachte vervangings vraag. 


\section{Huidige werkloosheid}

De huidige situatie op de arbeidsmarkt vormt vanzelfsprekend een belangrijke indicator van de relatieve marktpositie van de vrouwenopleidingen. In tabel 5.10. worden de werkloosheidscijfers per april 1991 voor de verschillende vrouwenopleidingen gepresenteerd ${ }^{33}$. Uit de tabel blijkt dat bij de meeste geselecteerde opleidingstypen het werkloosheidspercentage onder het gemiddelde ligt. Een uitzondering wordt daarbij gevormd door het opleidingstype 'LBO Verzorgend'. In zijn algemeenheid kan worden opgemerkt dat voor de diverse opleidingstypen het werkloosheidspercentage voor mannen en vrouwen weinig verschilt. Een uitzondering vormt hierbij het opleidingstype 'MBO Sociaal-Cultureel" waar de werkloosheid onder vrouwen hoger is dan onder mannen.

Tabel 5.10. Werkloosheid naar geslacht 'vrouwenopleidingen' april 1991 (bemiddelingsbestand zonder baan)

\begin{tabular}{lccc}
\hline Opleidingstype & mannen \\
& $\%$ & $\begin{array}{c}\text { werkloosheid } \\
\text { vrouwen } \\
\%\end{array}$ & $\begin{array}{c}\text { totaal } \\
\%\end{array}$ \\
\hline LBO Verzorgend & 10 & 10 & 10 \\
MBO Verpleging \& Ziekenverzorging & 3 & 2 & 2 \\
MBO Verzorgend & 2 & 3 & 3 \\
HBO Medisch Laboratorium & 3 & 1 & 1 \\
MBO Medisch Laboratorium & 1 & 2 & 4 \\
HBO Verpleging \& Paramedisch & 4 & 4 & 7 \\
MBO Sociaal-Cultureel & 5 & 8 & 8 \\
Totaal lalle opleidingstypen) & 8 & 9 & \\
\hline
\end{tabular}

Bron: Arbeidsvoorzieningsorganisatie/ROA

\section{Toekomstige arbeidsmarktperspectieven}

Naast de huidige (kwantitatieve) aansluiting tussen vraag en aanbod op de arbeidsmarkt, zoals die tot uitdrukking komt in de bovengenoemde werkloosheidspercentages, is vooral ook de toekomstige arbeidsmarktsituatie, gebaseerd op de verwachte stromen op de arbeidsmarkt, van groot belang voor de karakterisering van de marktpositie van de vrouwenopleidingen. In tabel 5.11. wordt het verwachte toekomstige arbeidsmarktperspectief voor deze opleidingstypen weergegeven.

33. Zoals reeds is opgemerkt geven de hier gepresenteerde werkloosheidspercentages slechts een indicatie van de relatieve ernst van de werkloosheid of krapte op de arbeidsmarkt voor de verschillende opleidingstypen. 
Tabel 5.11. Toekomstig arbeidsmarktperspectief 'vrouwenopleidingen' 1989-1994

Opleidingstype

indicator toekomstige

typering

arbeidsmarktsituatie

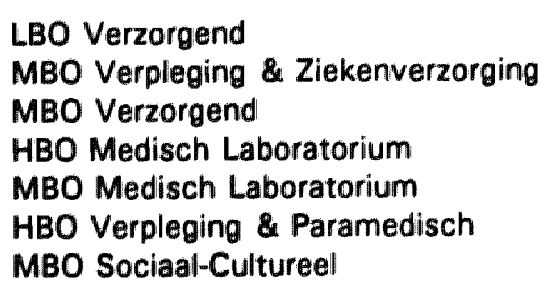

0,90

1,05

0,88

0,94

0,88

1,26

1,22 goed

redelijk

goed

goed

goed

slecht

slecht

Bron: ROA

Voor de opleidingstypen 'HBO Verpleging \& Paramedisch' en 'MBO Sociaal-Cultureel' zijn de toekomstige arbeidsmarktperspectieven slecht te noemen. Bij het eerstgenoemde opleidingstype heeft dit met name te maken met een relatief lage vraag naar nieuwkomers (zie tabel 5.9.). Het verwachte aantal baanopeningen voor het opleidingstype 'MBO Sociaal-Cultureel' is echter relatief hoog; het naar verwachting slechte arbeidsmarktperspectief wordt hier vooral veroorzaakt door de verwachte instroom van schoolverlaters met deze opleidingsachtergrond. Het toekomstig perspectief voor het opleidingstype 'MBO Verpleging \& Ziekenverzorging' wordt als redelijk getypeerd. Naar verwachting zijn de arbeidsmarktperspectieven voor de overige vrouwenopleidingen goed. Opvallend daarbij is de positie van het 'LBO Verzorgend', daar er momenteel nog sprake is van hoge werkloosheid onder deze opleidingscategorie.

\section{Uitwijkmogelijkheden}

Een slechte (toekomstige) arbeidsmarktsituatie hoeft niet automatisch te betekenen dat de schoolverlaters van de desbetreffende opleidingen een geringe kans op een baan hebben. Wellicht bestaat de mogelijkheid dat zij kunnen uitwijken naar andere beroepsdomeinen. Tabel 5.12. laat voor de zeven onderscheiden vrouwenopleidingen de uitwijkmogelijkheden op aansluitend on hoger functieniveau zien, aan de hand van de reeds eerder besproken GiniHirschman spreidingsindicator. Daarbij is het van belang om op te merken dat deze spreidingsindicator in feite de gerealiseerde en niet de potentiële vitwijkmogelijkheden in beeld brengt.

Opvallend is dat voor alle vrouwenopleidingen de beroepenspreiding gemiddeld of (erg) klein is. De arbeidskrachten met 'MBO Medisch Laboratorium' als opleidingsachtergrond hebben daarbij de geringste spreiding over de verschillende beroepsgroepen. Dit betekent derhalve dat deze opleiding relatief weinig mogelijkheden biedt om in andere beroepsgroepen terecht te komen. De lage beroepenspreiding hangt vanzelfsprekend samen met de wettelijk geregelde diploma-eisen voor deze vakdeelmarkten van medisch/verzorgende beroepen en waarvoor de genoemde vrouwenopleidingen beogen op te leiden. Er is dan sprake van een min of meer 'exclusieve' relatie tussen beroep en opleiding. Dit betekent overigens ook dat er binnen deze beschermde vakdeelmarkten weinig concurrentie met andere groepen opgeleiden bestaat. 
Tabel 5.12. Uitwijkmogelijkheden op aansluitend of hoger functieniveau 'vrouwenopleidingen' 1990

Opleidingstype

Gini-Hirschman typering indicator

LBO Verzorgend

MBO Verpleging \& Ziekenverzorging

0,89

0,72

gemiddeld

$M B O$ Verzorgend

0,90

HBO Medisch Laboratorium

0,72

MBO Medisch Laboratorium

0,66

HBO Verpleging \& Paramedisch

0,76

MBO Sociaal-Cultureel

0,90

klein gemiddeld

klein erg klein

klein gemiddeld

Bron: ROA

\section{Onderbenutting}

Naast de kwantitatieve aansluiting tussen onderwijs en arbeidsmarkt is vanzelfsprekend ook de kwalitatieve aansluiting van belang voor de marktpositie van een bepaald opleidingstype. Het hebben van een baan betekent immers niet dat deze baan automatisch in overeenstemming is met het niveau van de gevolgde opleiding. In tabel 5.13. is voor de onderscheiden vrouwenopleidingen aangegeven welk percentage van de beroepsbeoefenaren een beroep op een relatief te laag functieniveau uitoefent.

Tabel 5.13. Percentage onderbenutting 'vrouwenopleidingen' 1990

Opleidingstype

percentage

typering

onderbenutting

LBO Verzorgend

MBO Verpleging \& Ziekenverzorging

61

14

MBO Verzorgend

59

HBO Medisch Laboratorium

MBO Medisch Laboratorium

HBO Verpleging \& Paramedisch

MBO Sociaal-Cultureel

erg hoog

laag

erg hoog

laag

laag

laag

gemiddeld

Bron: ROA

De vrouwenopleidingen kunnen qua percentage onderbenutting in twee groepen worden opgesplitst. Aan de ene kant zijn er de opleidingstypen waarbij slechts een gering deel van de arbeidskrachten een functie onder het niveau van de opleiding uitoefent ('MBO Verpleging \& Ziekenverzorging', 'HBO Medisch Laboratorium', 'MBO Medisch Laboratorium' en 'HBO Verpleging \& Paramedisch'). Aan de andere kant hebben de opleidingstypen 'LBO Verzorgend" en 'MBO Verzorgend' een relatief erg hoog percentage werkenden dat wordt onderbenut. Het opleidingstype 'MBO Sociaal-Cultureel' neemt op dit punt een tussenpositie in. Wanneer deze 
typeringen worden vergeleken met de hierboven besproken uitwijkmogelijkheden, dan blijkt een sterk corresponderend beeld te ontstaan. De opleidingstypen met een laag onderbenuttingspercentage hebben vaak ook een lage spreiding over de verschillende beroepsgroepen, terwijl de opleidingstypen met een hoog onderbenuttingspercentage gekenmerkt worden door min of meer gemiddelde vitwijkmogelijkheden op de arbeidsmarkt.

De geselecteerde vrouwenopleidingen hebben in het algemeen een zeer specifieke marktpositie. De uitwijkmogelijkheden van deze opleidingen zijn vrij gering, hetgeen een negatief effect heeft op hun relatieve marktpositie. Daar staat tegenover dat het percentage werkenden dat in hun kwalificatie wordt onderbenut, met uitzondering van de verzorgende opleidingen op LBO- en MBO-niveau, eveneens gering is, hetgeen gezien kan worden als een positief aspect van de marktpositie. Dit hangt samen met de sterk gereguleerde markten waarin degenen met deze opleidingsachtergrond terecht komen. Het betekent wel dat de kans op werk voor deze opleidingstypen sterk afhankelijk is van de (toekomstige) vraag-en aanbodverhoudingen op de specifieke arbeidsmarkten waarvoor men wordt opgeleid. Met name voor 'HBO Verpleging \& Paramedisch' en 'MBO Sociaal-Cultureel' wordt wat dit betreft op de middellange termijn een slecht arbeidsmarktperspectief verwacht. 


\section{LITERATUUR}

Berendsen, H., R.J.P. Dekker, A. de Grip, P.J.E. van de Loo (1992), Prognose arbeidsmarktinstroom van schoolverlaters per op/eidingstype, ROA-W-1992/2, Maastricht.

Berendsen, H., A. de Grip, E.J.T.A. Willems (1991), De arbeidsmarkt voor onderzoekers 1990 2010, Ministerie van Economische Zaken, Beleidsstudies Technologie Economie nr. 13, 'sGravenhage.

Bruyn-Hundt, M. (1988), Vrouwen op de arbeidsmarkt, Nederlandse situatie in de jaren tachtig en negentig, Scala-reeks, Het Spectrum, Utrecht.

Centraal Bureau voor de Statistiek (1984), Beroepenclassificatie 1984, Voorburg/Heerlen.

Centraal Bureau voor de Statistiek (1989), Standaard Onderwijs Indeling 1978, Voorburg/Heerlen.

Centraal Planbureau (1987), De arbeidsmarkt naar opleidingscategorie, CPB-Werkdocument No. 17, 's-Gravenhage.

Dekker, R.J.P., A. de Grip, H. Berendsen, M.H. Wieling, E.J.T.A. Willems (1992), Methodiek en structuur arbeidsmarktmodule I-See/ 1991, ROA-W-1992/1, Maastricht.

Dekker, R.J.P., A. de Grip, P.J.E. van de Loo (1990), ROA-Beroepenclassificatie 1990, ROA-W1990/9, Maastricht.

Grip, A. de (1987), Winnaars en verliezers op de arbeidsmarkt, Tijdschrift voor Arbeidsvraagstukken, jrg. 3, nr. 1987/4, blz. 61-69.

Grip, A. de, L.F.M. Groot, J.A.M. Heijke, E.J.T.A. Willems (1990), De aans/uiting tussen beroepen en functies en de relatie met scholings- en mobiliteitsprocessen, OSA-werkdocument W80, 's-Gravenhage.

Grip, A. de, J.A.M. Heijke (1988), Arbeidsmarktindicatoren: een inventarisatie, ROA-W-1988/1, Maastricht.

Grip, A. de, R.K.W. van der Velden, M.H. Wieling (1991), Indicatoren aans/uiting anderwijsarbeidsmarkt MDGO, ROA-R-1991/2, Maastricht.

Grip, A. de, E.J.T.A. Willems (1992), De vervangingsvraag naar beroepsklasse tot 2000, OSApublikatie, te verschijnen.

Groot, L.F.M. (1990), De onderwijs- en beroepssegregatie tussen mannen en vrouwen in de eerste helft van de jaren tachtig, Tijdschrift voor Arbeidsvraagstukken, jrg. 6, nr. 1990/4, blz. 4-12.

Huijgen, F. (1989), De kwalitatieve structuur van de werkgelegenheid in Nederland, deel III, OSA-voorstudie V33, 's-Gravenhage.

Instituut voor Arbeidsvraagstukken (1992), Verbeterde arbeidsmarktramingen voor leraren in het primair onderwijs, IVA, Tilburg.

Ministerie van Economische Zaken (1990), Economie met open grenzen, Tweede Kamer, vergaderjaar 1989-1990, nrs. 1-2, "s-Gravenhage. 
$-70-$

Ministerie van Onderwijs en Wetenschappen (1991), Referentieraming 1991, 's-Gravenhage.

Ministerie van Sociale Zaken en Werkgelegenheid (1989), Rapportage arbeidsmarkt 1989, 'sGravenhage.

Ministerie van Sociale Zaken en Werkgelegenheid (1990), Rapportage arbeidsmarkt 1990, 'sGravenhage.

Ministerie van Sociale Zaken en Werkgelegenheid (1991), Rapportage arbeidsmarkt 1991, "sGravenhage.

Mourik, A. van, J.J. Siegers (1988), Ontwikkelingen in de beroepssegregatie tussen mannen en vrouwen, 1971-1985, Economisch Statistische Berichten, jrg. 73, nr. 3668, blz. 732-737.

Opstal, R. van (1989), Arbeidsaanbod en werkgelegenheid naar 11 opleidingscategorieēn 19852000; een actualisering van werkdocument 17, Interne notitie CPB II/1989/25, 'sGravenhage.

Siegers, J.J. (1979), Beroepssegregatie tussen mannen en vrouwen in Nederland, Economisch Statistische Berichten, jrg. 64, nr. 3194, blz. 208-213.

Voogd, J. de, R. Olieman (1990), Ontwikkelingen op de arbeidsmarkt van leerkrachten in het voortgezet en hoger onderwijs tot 2000; TEASE-88, Stichting Het Nederlands Economisch Instituut, Rotterdam.

Wieling, M.H., R.J.P. Dekker, A. de Grip (1991), Landelijke en regionale werkloosheidsindicatoren 1991, ROA-R-1991/8, Maastricht.

Wieling, M.H., A. de Grip, E.J.T.A. Willems (1990), Een systematische kwalitatieve typering van arbeidsmarktinformatie, ROA-W-1990/8, Maastricht.

Willems, E.J.T.A., A. de Grip (1990), Vervangingsvraagprognoses naar beroep en opleiding, ROA-W-1990/7, Maastricht. 


\section{ENKELE CENTRALE BEGRIPPEN}

\section{Afhankelijkheid van schoolverlaters per beroepsk/asse}

Mate waarin een beroepsklasse afhankelijk is van de instroom van jongeren, bepaald op basis van het percentage werkenden jonger dan 30 jaar.

\section{Baanopeningen}

Totale vraag naar nieuwe arbeidskrachten als de som van de (positieve) uitbreidingsvraag en de vervangingsvraag.

\section{Conjunctuurgevoeligheid per beroepsklasse}

Mate van werkzekerheid, bepaald door de sectorale werkgelegenheidsfluctuaties in het verleden te relateren aan de mate waarin een beroepsklasse momenteel aanwezig is in de verschillende bedrijfssectoren.

\section{Instroom van schoolverlaters}

Aanbod van nieuwe arbeidskrachten op de arbeidsmarkt, bepaald door in aanvulling op de uitstroom van schoolverlaters uit het initiële dagonderwijs rekening te houden met de afgestudeerden van het deeltijdonderwijs, het niet-reguliere onderwijs en de volwasseneneducatie (zie verder Berendsen, Dekker, De Grip en Van de Loo, 1992).

\section{Kortdurige werkloosheid}

Degenen die minder dan één jaar werkloos zijn (zie verder onder "werkloosheid").

\section{Onderbenutting}

Treedt op als het functieniveau van de arbeidskrachten te laag is ten opzichte van het opleidingsniveau (zie verder Huijgen, 1989).

\section{Toekomstige arbeidsmarktperspectieven}

Kans op absorptie- of schaarsteproblemen in de toekomst, bepaald met behulp van de indicator toekomstige arbeidsmarktsituatie, waarbij een confrontatie wordt gemaakt van enerzijds de verwachte uitbreidings- en vervangingsvraag en anderzijds de verwachte instroom van schoolverlaters en de kortdurige werkloosheid.

\section{Uitbreidingsvraag}

Vraag naar nieuwe arbeidskrachten op grond van de ontwikkeling van de werkgelegenheid.

\section{Uitwijkmogelijkheden per opleidingstype}

Mate waarin arbeidskrachten met een bepaalde opleidingsachtergrond kunnen 'uitwijken' naar andere beroepsgroepen op aansluitend of hoger functieniveau, bepaald met behulp van de Gini-Hirschman spreidingsindex. Deze maatstaf geeft daarmee aan in hoeverre degenen met de desbetreffende opleidingsachtergrond afhankelijk zijn van de werkgelegenheidsontwikkeling in een bepaald beroep. 


\section{Vervangingsvraag}

Vraag naar nieuwe arbeidskrachten vanwege pensionering, (tijdelijke) terugtrekking van d arbeidsmarkt e.d. De vervangingsvraag per beroepsklasse kan daarnaast het gevolg zijn va de beroepsmobiliteit (zie verder Willems en De Grip, 1990).

\section{Werkloosheid}

Aantal ingeschrevenen bij de arbeidsbureaus, dat momenteel geen betaalde baan heeft, zic voor tenminste 20 uur per week aanbiedt op de arbeidsmarkt en bovendien binnen twe weken beschikbaar is om een betaalde baan te aanvaarden (bemiddelingsbestand zonde baan). 
